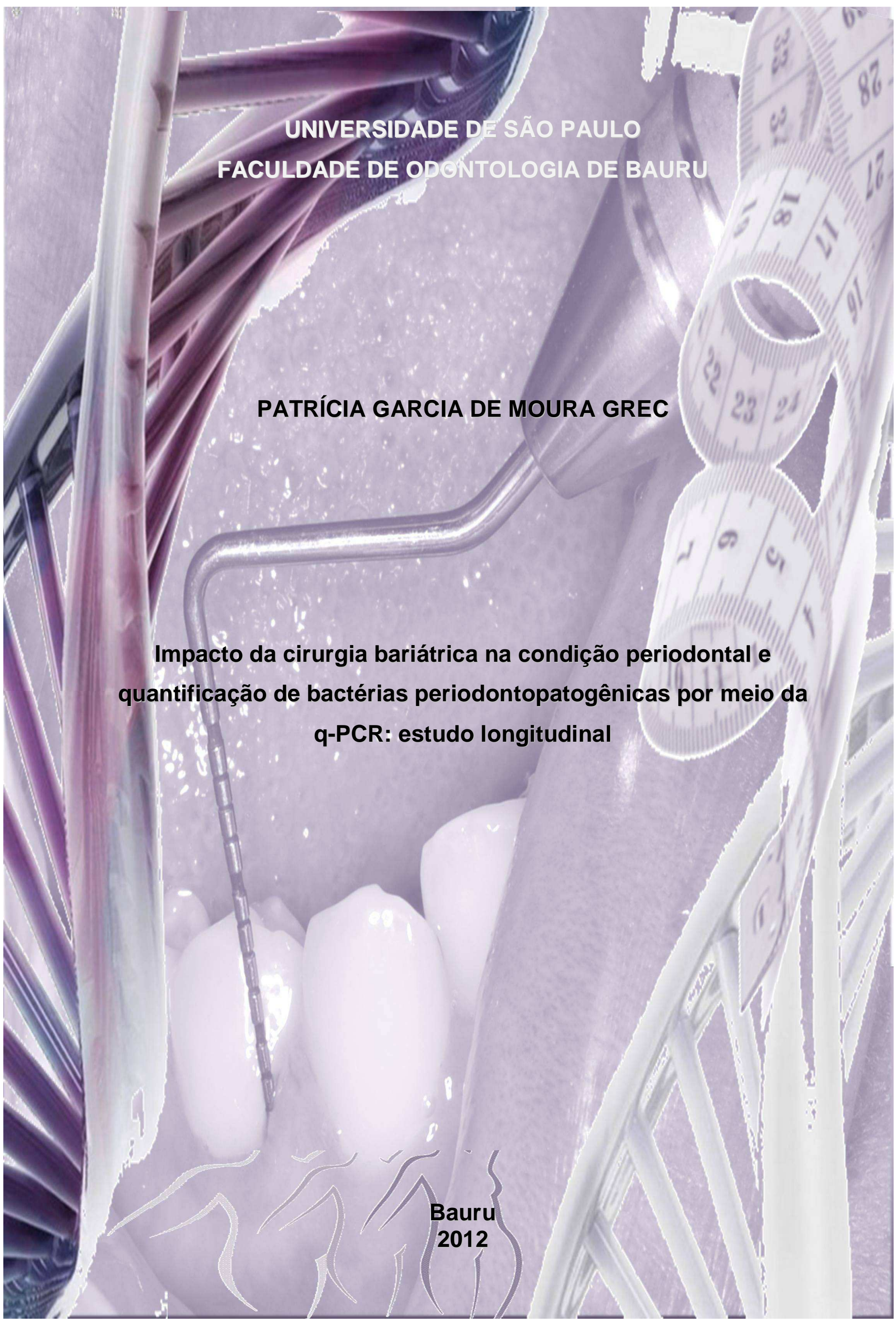





\section{PATRÍCIA GARCIA DE MOURA GREC}

Impacto da cirurgia bariátrica na condição periodontal e quantificação de bactérias periodontopatogênicas por meio da q-PCR: estudo longitudinal

Tese apresentada à Faculdade de Odontologia de Bauru da Universidade de São Paulo para obtenção do título de Doutor em Ciências Odontológicas Aplicadas, na área de concentração Ortodontia e Odontologia em Saúde Coletiva.

Orientadora: Prof ${ }^{\mathrm{a}} \mathrm{Dr}^{\mathrm{a}}$ Sílvia Helena de Carvalho Sales Peres

Versão corrigida 


\begin{tabular}{|l|}
\hline Moura-Grec, Patrícia Garcia de \\
M865i $\quad$ Impacto da cirurgia bariátrica na condição periodontal e \\
quantificação de bactérias periodontopatogênicas por meio da \\
q-PCR: estudo longitudinal / Patrícia Garcia de Moura Grec. - \\
Bauru, 2012. \\
116p. ; il. ; $31 \mathrm{~cm}$. \\
Tese. (Doutorado) - Faculdade Odontologia de \\
Bauru. Universidade de São Paulo. \\
Orientadora: Prof $^{\mathrm{a}} \operatorname{Dr}^{\text {a }}$ Sílvia Helena de Carvalho Sales Peres \\
\end{tabular}

Nota: A versão original desta tese encontra-se disponível no Serviço de Biblioteca e Documentação da Faculdade de Odontologia de Bauru - FOB/USP.

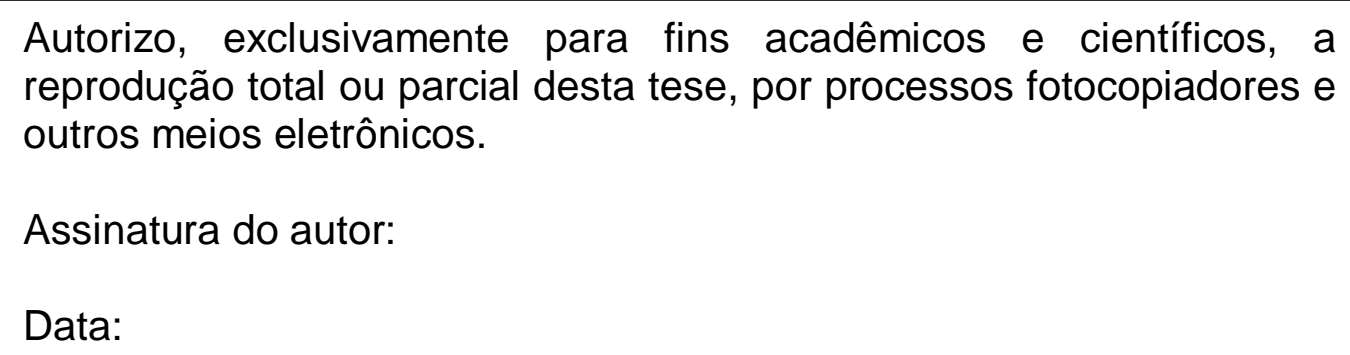
reprodução total ou parcial desta tese, por processos fotocopiadores e outros meios eletrônicos.

Assinatura do autor:

Data:

\begin{tabular}{|c|c|c|}
\hline CEP & Protocolo № & Data \\
\hline HB/FAMERP & № 315/08 & $11 / 08 / 2008$ \\
\hline HC/FMB & № 468/08 & 03/11/2008 \\
\hline HC/HCRP & № 12384/09 & $17 / 03 / 2010$ \\
\hline
\end{tabular}


FOLHA DE APROVAC̣ÃO 



\section{DEDICATÓRIA}

Ao meu tio Renê (in memorian), pois não tem como não se lembrar dessa pessoa incrível quando se fala em ciência, estudos, pesquisa. Suas doces palavras de incentivo a seguir a carreira acadêmica me trouxeram até aqui. Sinto muito a sua falta. 



\section{AGRADECIMENTOS ESPECIAIS}

A Deus por me abençoar com saúde, com sabedoria e com uma vida cheia de pessoas tão maravilhosas ao meu redor. Obrigada por nunca me abandonar!

Aos meus amados Pais, Wilson e Madalena, pelo amor incondicional. Difícil demais encontrar palavras para expressar tamanha gratidão que tenho por tudo 0 que vocês fizeram por mim, abdicando de seus sonhos para realizarem os meus. Por todo esforço que fizeram para me dar o melhor, por me ensinar a viver com dignidade, por investirem na minha educação e pelo carinho e dedicação que iluminaram os meus caminhos para que eu pudesse seguir sem medo. Tenho orgulho de ser sua filha. Amo vocês! Muito obrigada!

Ao meu marido Roberto pelo amor verdadeiro, pelo companheirismo intenso, pelo apoio incondicional, por estar ao meu lado nos momentos mais difíceis me dando força e palavras de incentivo. Por isso agradeço a Deus todos os dias por ter colocado você na minha vida. Obrigada por ser tão preocupado comigo, o que mostra o quanto você me quer bem. Obrigada pela ajuda enorme que você me deu no desenvolvimento deste trabalho. Por me acalmar nas horas de angústia $e$ por duplicar minha felicidade nos momentos alegres. Te amo muito! 

Aos meus queridos irmãos que tanto amo:

à Renata, pela coragem e determinação, fontes de inspiração que eu carrego comigo para ver se um dia chego à metade do que você é. Obrigada pelo amor e pela união sempre.

à Silvinha, companheiríssima desde a infância $e$ até na pesquisa me ajudando com o grupo controle. Agradeço pelas suas orações, por todo amor e carinho que você tem comigo.

ao Wilson Henrique, o caçula que dá show de sabedoria nas irmãs, com quem estou sempre aprendendo algo novo. Obrigada pelo carinho, pela amizade e pelo amor.

Aos meus amados sobrinhos Rafael, Amanda, Vinícius e Rafael Henrique que abastecem minha vida de alegria.

Ao meu sogro Pedro e a minha sogra Zuleica por me acolher como filha. A certeza disso é o imenso carinho e apoio que sempre recebo de vocês. 

A minha estimada Orientadora, Prof Dra Sílvia Helena de Carvalho Sales Peres, pela total confiança em mim depositada, por toda ajuda desde os tempos da especialização, me acolhendo com imenso carinho no doutorado e sempre me preparando para mais conquistas. Seu amor pela profissão e tamanha dedicação são fontes de inspiração e exemplos a serem seguidos. Estendo este agradecimento ao Prof. Dr. Arsenio Sales Peres. Agradeço por vocês não medirem esforços para transmitir tanto conhecimento e buscar oportunidades para complementar minha formação. Por se preocuparem com meus próximos passos, apoiando, ensinando e orientando. Mais que professores, são meus amigos e padrinhos que levarei para sempre no meu coração e terei eterna gratidão. 



\section{AGRADECIMENTOS}

A todos meus queridos familiares, meu avô, meus tios e tias, meus cunhados, meus primos, com quem sempre aprendo um pouco mais da vida e que prezam pela união da família. Em especial à tia Biguinha $e$ ao Tio Bertão que me acolheram com tanto carinho nos dias de coleta de dados em Botucatu, o que fazia valer a pena a viagem. E à Mariana Andreoli, por me fazer companhia muitas vezes à Botucatu, me ajudando na coleta de dados e por ser minha "filhinha" de Bauru, estando sempre por perto quando precisei.

Aos grandes amigos que levarei para sempre em meu coração:

À Gabriela Gennaro, grande parceira desde a graduação, $e$ ainda mais unidas quando o destino nos levou para o mestrado em Florianópolis e depois para 0 doutorado em Bauru, sendo uma super companheira, uma irmã. Agradeço pela sua amizade verdadeira, por compartilhar os momentos alegres e oferecer seu ombro nos momentos difíceis

À Marta Mapengo e Juliane Marsicano, meus primeiros contatos quando cheguei para 0 doutorado, $e$ desde então nasceu uma grande amizade. 0 trio que nem a distância separa. Marta, que voltou para Moçambique e ocupa um grande espaço no meu coração, the agradeço pela bagagem cultural que você me acrescentou, pelo companheirismo nos primeiros anos do doutorado e por continuar torcendo por mim mesmo estando tão longe. Ju, sempre tão prestativa, foi uma grande parceira neste trabalho. Agradeço por toda ajuda desde o projeto até os últimos dias de coleta, pela sua companhia nas viagens para Ribeirão, por dividir os medos da chuva e da neblina nas estradas, por compartilhar os momentos difíceis $e$ comemorar os felizes comigo. Obrigada por tudo que aprendi com vocês minhas queridas. 

À Joselene Yamashita, quem tive o prazer de co-orientar na iniciação científica, se tornou mais do que colega de pós-graduação, mas uma grande amiga. Agradeço pela ajuda incondicional na coleta de dados e no laboratório, pela companhia nas viagens para Rio Preto e Botucatu, pelo seu apoio até altas horas durante a fase final deste trabalho e pelos momentos de muitas risadas para descontrair. Obrigada pela amizade e pelo carinho.

Ao casal Cris e Fabio, por todo apoio e ajuda sempre que precisei, pela agradável companhia $e$ altos papos no bandejão, por compartilhar de tantos momentos de descontração, essenciais para aliviar o stress e dar força para seguir em frente.

Obrigada pela amizade verdadeira.

À Rosinha, funcionária da Disciplina de Saúde Coletiva, um anjo de pessoa que nunca negou um pedido meu, the agradeço por cuidar e organizar os materiais da pesquisa com tanto carinho, por ser tão prestativa, gentil e verdadeira amiga.

Aos amigos de pós-graduação, em especial Adriana, Pati Matos, Juliherme, Águeda e Cheila pela convivência harmoniosa e divertida.

À aluna de graduação Ana Célia pela ajuda na obtenção do grupo controle, por confiar na minha co-orientação em sua iniciação científica, pela sua amizade $e$ pelo bom humor que proporciona momentos agradáveis ao seu lado.

Aos médicos e professores Dr. Reginaldo Ceneviva (HCRP-USP), Dr. Celso Leite (FMB-UNESP), Dr. Gilberto Brito (FAMERP) e Dr. Sérgio Brienze (FAMERP) pela confiança e oportunidade dada para que eu pudesse coletar minha amostra nos respectivos hospitais. Pelo carinho com que me receberam, por me fazer imergir na ciência médica, sempre esclarecendo minhas dúvidas.

Às funcionárias dos hospitais onde foi realizada a coleta de dados deste trabalho, Maria (secretária FAMERP), Vilma (assistente social FAMERP), Renata (enfermeira UNESP), Dra Helenice e Lídia (psicólogas HCRP) e Dra Camila (nutróloga HCRP), por facilitar 0 andamento da pesquisa, principalmente quanto ao acesso aos prontuários, à disponibilidade de salas para 0 atendimento, ao agendamento dos pacientes e por toda atenção que me foi dada. 

A Prof ${ }^{a} r^{a}$ Elza Araújo Torres, do setor de Imunogenética do Hospital de Anomalias Craniofaciais - USP, por me acolher com tanta simpatia e amizade no seu laboratório, não só permitindo a utilização do espaço e dos equipamentos no momento que mais precisei, mas também participando de tudo com tanto entusiasmo, alegria e paixão pela ciência que faziam meus "dias de laboratório" mais felizes! Obrigada por tudo que me ensinou. Serei eternamente grata.

Ao Thiago José Dionísio, técnico do laboratório das Disciplinas de Fisiologia e Farmacologia, por toda ajuda que me foi dada na etapa laboratorial deste trabalho, por esclarecer todas as minhas dúvidas $e$ diante de todas as dificuldades sempre deu um jeito de não me deixar na mão. Sua participação foi essencial para o desenvolvimento da minha tese e por isso é tão difícil encontrar palavras que possam te agradecer como merece.

À Prof ${ }^{a} r^{a}$ Aparecida Maria Catai, do Departamento de Fisioterapia da Universidade Federal de São Carlos, orientadora de uma pesquisa de mestrado em que tive a honra de participar como examinadora da condição bucal dos pacientes, permitindo a obtenção de uma parte do meu grupo controle. Obrigada pela confiança em mim depositada.

Ao Prof. Dr. José Roberto Lauris, com sua maneira de transformar em simples algo que parece tão complexo, esclarecendo minhas dúvidas sempre que precisei e transmitindo os valiosos ensinamentos de estatística que possibilitaram interpretação e confiabilidade nos resultados desta pesquisa.

Aos demais Professores da Disciplina de Saúde Coletiva da FOB-USP, Prof. Dr.

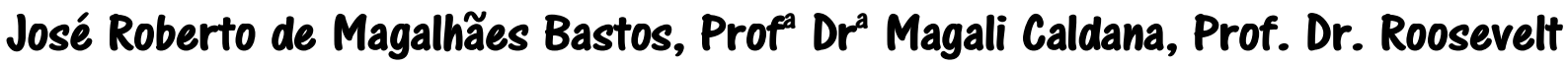
Bastos, Prof. Dr. Heitor Honório e Prof ${ }^{a}$ Dr $^{a}$ Nilce Tomita por enriquecerem meu aprendizado por meio dos ensinamentos transmitidos, pela atenção e pela amizade.

À Sílvia Tonin, secretária da Disciplina de Saúde Coletiva, pela dedicação e prontidão, sempre solícita quando precisei. 

À Faculdade de Odontologia de Bauru (FOB-USP), na pessoa do diretor Prof. Dr. José Carlos Pereira, instituição que me acolheu desde a graduação com a gentileza e dedicação dos professores e funcionários que nela trabalham.

À Comissão de pós-graduação, na pessoa do presidente Prof. Dr. Paulo César Rodrigues Conti.

À Fundação de Amparo à Pesquisa do Estado de São Paulo (FAPESP) pela concessão da bolsa de doutorado (Processo n ${ }^{0} 2008 / 05798-2$ ).

Aos pacientes desta pesquisa, pela paciência, confiança e compreensão.

E a todos aqueles que de alguma forma contribuíram para a realização deste trabalho.

\section{MUITO OBRIGADA!}



Resumo 



\section{RESUMO}

Este estudo longitudinal teve como objetivo avaliar o impacto da cirurgia bariátrica na condição periodontal e quantificar bactérias periodontopatogênicas em pacientes submetidos a esta cirurgia. Trata-se de um estudo prospectivo, composto por 50 pacientes submetidos à cirurgia bariátrica por derivação gastrojejunal em $Y$ de Roux, em 3 hospitais do estado de São Paulo. A coleta de dados foi realizada em três períodos: pré-operatório, pós-operatório de 6 e de 12 meses e consistiu de: avaliação do fluxo salivar; exame clínico bucal para avaliar desgaste dentário e doença periodontal; coleta de amostras do fluido gengival para quantificação das bactérias periodontopatogênicas Porphyromonas gingivalis, Tannerella forsythia, Treponema denticola e Prevotella intermedia por meio de Reação em Cadeia da Polimerase em Tempo Real (q-PCR); aplicação de questionário relacionado aos fatores para ocorrência de desgaste dentário e autopercepção da saúde bucal; avaliação do peso e altura para obtenção do índice de massa corporal (IMC) e coleta de dados complementares relacionados à saúde do indivíduo, por meio do prontuário médico. No baseline, 51 pacientes com IMC normal foram analisados e comparados aos obesos. ANOVA, teste de Tukey, correlação de Pearson e teste $t$ de Student foram utilizados na análise estatística $(p<0,050)$. No baseline, foi observado maior índice de sangramento gengival (ISG), presença de cálculo e sítios com bolsa 4-5 mm em obesos comparados ao grupo controle $(p<0,050)$, que mostrou uma melhor autopercepção da saúde bucal do que os obesos $(p=0,008)$. A

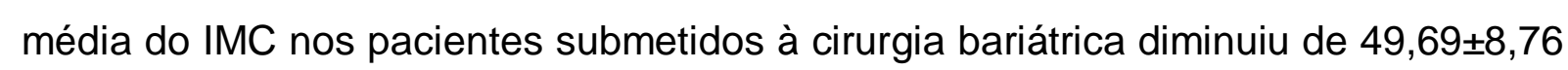
$\mathrm{kg} / \mathrm{m}^{2}$ para $36,16 \pm 8,12 \mathrm{~kg} / \mathrm{m}^{2}$ e para $32,26 \mathrm{~kg} / \mathrm{m}^{2}$ após 6 e 12 meses da cirurgia $(p<0,000)$, respectivamente. Antes da cirurgia, $67 \%$ dos pacientes apresentavam altos níveis séricos de proteína C-reativa (PCR) e 38\% glicemia alta. Houve redução significativa nos níveis séricos de PCR e glicose após a cirurgia. O fluxo salivar foi similar nos três períodos variando de 0,86-0,96 $\mathrm{mL} / \mathrm{min}$. Após a cirurgia bariátrica, o percentual de faces dentárias com desgaste em dentina aumentou significativamente $(p=0,002)$, enquanto que em esmalte diminuiu $(p=0,019)$, indicando aumento na severidade do desgaste dentário nestes pacientes. A média da profundidade de sondagem (PS) e do nível de inserção clínica (NIC) aumentou significativamente no pós-operatório de 6 meses $(p<0,000)$. No mesmo período a quantidade de $P$. gingivalis aumentou $(p=0,028)$ e das outras bactérias diminuiu 

discretamente $(p>0,050)$. Em presença das bactérias $P$. gingivalis, T. forsythia, $T$. denticola e $P$. intermedia a condição periodontal se mostrou pior. Concluiu-se que a cirurgia bariátrica promoveu impacto negativo nas condições de saúde bucal, especialmente doença periodontal e desgaste dentário. Foram observadas alterações na quantidade de bactérias periodontopatogênicas nos pacientes avaliados durante os três períodos, sendo que a $P$. gingivalis acompanhou 0 aumento da severidade da doença periodontal.

Palavras-chave: Cirurgia bariátrica. Doenças periodontais. Saúde bucal. Erosão dentária. Obesidade. Reação em cadeia da polimerase. Porphyromonas gingivalis. 



$$
\text { Abstract }
$$





\section{ABSTRACT \\ Impact of bariatric surgery on periodontal status and quantification of periodontopathogenic bacteria using q-PCR: longitudinal survey}

The aim of this longitudinal study was to evaluate the impact of bariatric surgery on periodontal condition and quantify periodontopathogenic bacteria in patients undergoing this surgery. This was a prospective study composed of 50 patients who underwent bariatric surgery for Roux-en-Y gastric bypass in three hospitals in the state of São Paulo. Data collection was performed in three periods: preoperative, postoperative of 6 and 12 months and consisted of: salivary flow evaluation; oral clinical examination to assess tooth wear and periodontal disease; gingival fluid sample collection for quantification of periodontopathogenic bacteria Porphyromonas gingivalis, Tannerella forsythia, Treponema denticola and Prevotella intermedia using Real-time Polymerase Chain Reaction (q-PCR); questionnaire applied as regards factors related to occurrence of tooth wear and self-perceived oral health; weight and height evaluation to determine the body mass index (BMI), in addition to collection of individual's health-related data from medical files. At baseline, 51 patients with normal BMI were analyzed and compared with obese subjects. ANOVA, Tukey test, Pearson correlation and Student's $t$-test were used for statistical analysis $(p<0.050)$. At baseline, greater gingival bleeding index (GBI), presence of calculus and sites with 4-5 $\mathrm{mm}$ pocket depth were observed in obese compared with the control group $(p<0.050)$, which showed better self-perceived oral health than the obese $(p=0.008)$. Mean BMI decreased from $49.69 \pm 8.76 \mathrm{~kg} / \mathrm{m}^{2}$ to $36.16 \pm 8.12 \mathrm{~kg} / \mathrm{m}^{2}$ and to $32.26 \mathrm{~kg} / \mathrm{m}^{2}$ after 6 and 12 months postoperatively ( $p<0.000$ ), respectively. Before surgery $67 \%$ of patients had high C-reactive protein (CRP) serum levels and $38 \%$ high glucose level. There was significant reduction in serum CRP and glucose after surgery. Salivary flow was similar in all three periods, ranging from 0.86 to $0.96 \mathrm{~mL} / \mathrm{min}$. After bariatric surgery, the percentage of tooth surfaces with dentin wear increased significantly $(p=0.002)$, while enamel wear decreased $(p=0.019)$, indicating increase in the severity of tooth wear in these patients. The mean probing depth (PD) and clinical attachment level (CAL) increased significantly in the postoperative period of 6 months $(p<0.000)$. In the same period the amount of $P$. gingivalis increased $(p=0.028)$ and of other bacteria decreased slightly $(p>0.050)$. In the presence of 

P. gingivalis, T. forsythia, T.denticola and $P$. intermedia, a worse periodontal condition was observed. It was concluded that bariatric surgery promoted negative impact on oral health conditions, especially periodontal disease and tooth wear. Changes were observed in the amount of periodontopathogenic bacteria in the patients evaluated during the three periods, and $P$. gingivalis accompanied the increased periodontal disease severity.

Keywords: Bariatric surgery. Periodontal diseases. Oral health. Dental erosion. Obesity. Polymerase chain reaction. Porphyromonas gingivalis. 



\section{LISTA DE FIGURAS}

Figura 1 - Derivação gastrojejunal em Y-de-Roux

Figura 2 - Paciente avaliada antes e após a cirurgia bariátrica 43

Figura 3 - Sonda periodontal Carolina do Norte-15 48

Figura 4 - Exame bucal 48

Figura 5 - Avaliação da profundidade de sondagem 50

Figura 6 - Coleta do fluido gengival 53

Figura 7 - Montagem da placa de q-PCR 56

Figura 8 - Colocação da placa no termociclador.

Figura 9 - Gráfico de dispersão e linha de tendência exponencial obtidos dos valores dos Cts das curvas padrão para a bactéria $P$. gingivalis. 58

Figura 10 - Tamanho da amostra nos 3 períodos avaliados e motivos das perdas. 66

Figura 11-Gráfico dos valores da quantificação relativa $(R Q)$ das bactérias $T$. forsythia, $T$. denticola e $P$. intermedia nos 3 períodos avaliados. 



\section{LISTA DE TABELAS}

Tabela 1- Sequência dos primers e temperatura de anelamento $\left(T_{a}\right)$ 55

Tabela 2 - Distribuição da severidade e prevalência de desgaste dentário por grupo de dentes dos pacientes obesos indicados à cirurgia bariátrica.

Tabela 3 - Comparação das variáveis entre os grupos controle e obeso

Tabela 4 - Alterações observadas nas variáveis ao longo do tempo $(\mathrm{n}=50)$

Tabela 5 - Índice periodontal comunitário (IPC), avaliado pelos dentes índices, para pacientes obesos antes e após a cirurgia bariátrica

Tabela 6 - Índice periodontal comunitário (IPC), avaliado para todos os dentes presentes ("boca toda"), para pacientes obesos antes e após a cirurgia bariátrica.

Tabela 7 - Média das variáveis de acordo com a presença (Sim) e ausência (Não) de P.gingivalis comparadas nos 3 períodos avaliados pela ANOVA

Tabela 8 - Média das variáveis de acordo com a presença (Sim) e ausência (Não) de T. forsythia comparadas nos 3 períodos avaliados pela ANOVA

Tabela 9 - Média das variáveis de acordo com a presença (Sim) e ausência (Não) de $T$. denticola comparadas nos 3 períodos avaliados pela ANOVA

Tabela 10 - Média das variáveis de acordo com a presença (Sim) e ausência (Não) de $P$. intermedia comparadas nos 3 períodos avaliados pela ANOVA 



\section{LISTA DE QUADROS}

Quadro 1- Números dos protocolos de aprovação dos Comitês de Ética

Quadro 2-Valores considerados normais para níveis de cálcio, proteína C-reativa, PTH e glicose. 46

Quadro 3-Classificação do estado nutricional, através do IMC (WHO, 1998) 46

Quadro 4- Classificação do fluxo salivar... 49

Quadro 5- Índice de desgaste dentário (IDD)- códigos e critérios utilizados 49

Quadro 6- Códigos e critérios do IPC 52 



\section{SUMÁRIO}

REVISÃO DA LITERATURA

MATERIAL E MÉTODOS.

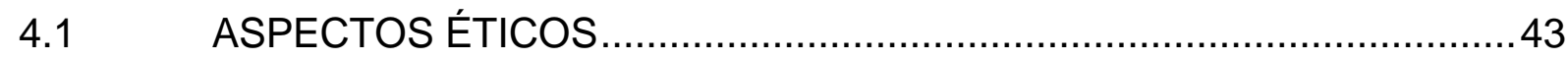

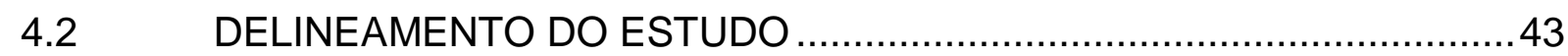

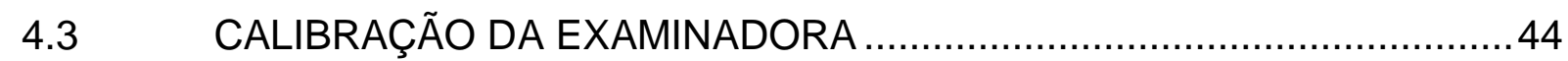

$4.4 \quad$ COMPOSIÇÃO DA AMOSTRA E ESTUDO PILOTO …..........................44

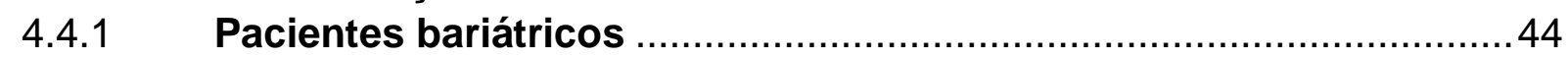

4.4.2 Pacientes não obesos (grupo controle) ….................................... 45

4.5 DADOS DO PARTICIPANTE E INFORMAÇÕES

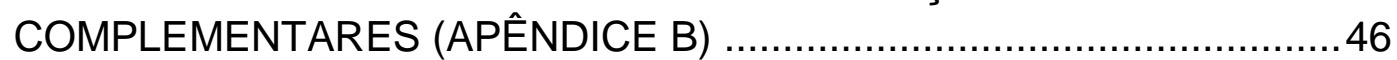

$4.6 \quad$ APLICAÇÃO DE QUESTIONÁRIO (APÊNDICE C) ……....................4 4

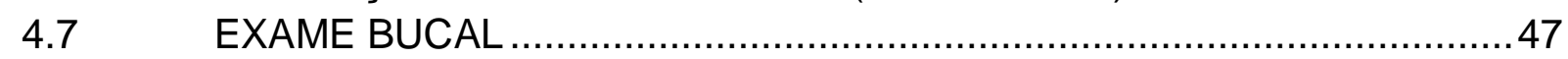

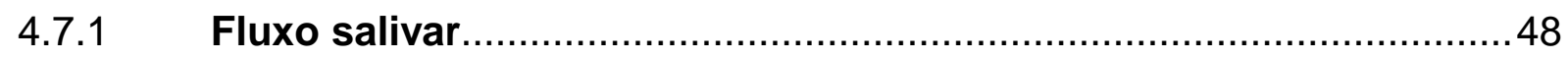

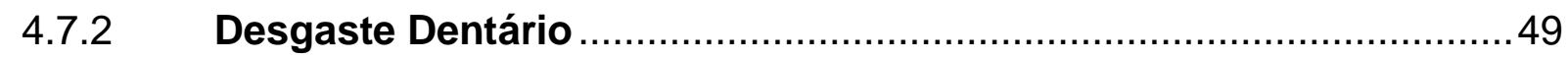

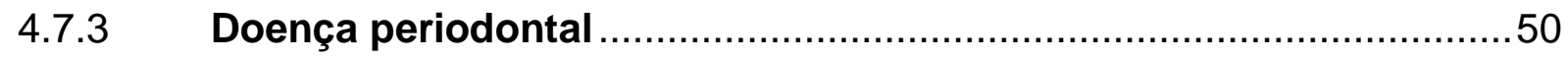

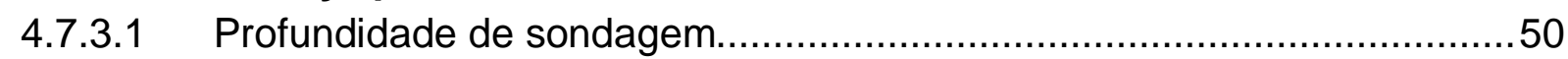

4.7.3.2 Índice de sangramento gengival - ISG ….......................................51

4.7.3.3 Nível de Inserção clínica/ recessão gengival........................................51

4.7.3.4 Índice Periodontal Comunitário.............................................................51

4.7.4 Coleta de amostra do fluido gengival ...........................................52

4.8 DETECÇÃO E QUANTIFICAÇÃO DE BACTÉRIAS

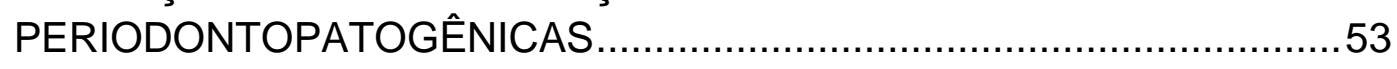

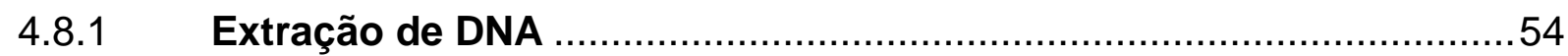

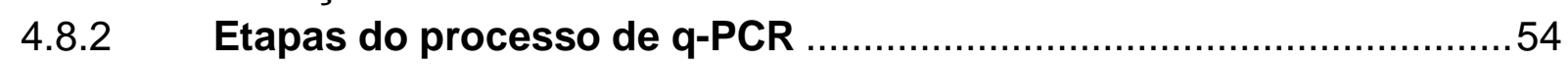

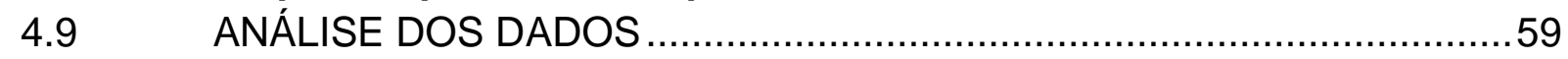



RESULTADOS

5.1 AVALIAÇÃO PRÉ CIRURGIA BARIÁTRICA .....................................63

5.1.1 Pacientes obesos mórbidos (baseline) .........................................63

5.1.2 Comparação com um grupo controle (IMC normal) ..........................65

5.2 AVALIAÇÃO APÓS CIRURGIA BARIÁTRICA .................................... 65

5.3 BACTÉRIAS PERIODONTOPATOGÊNICAS -

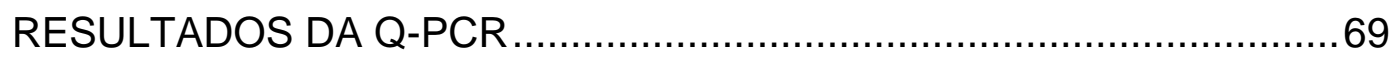

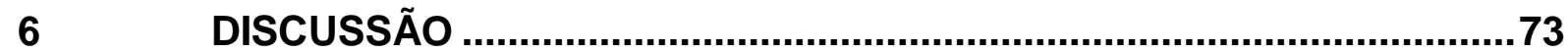

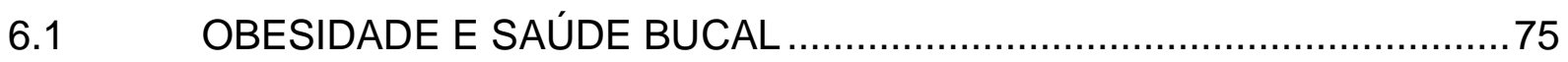

6.2 CIRURGIA BARIÁTRICA: CONSEQUÊNCIAS SISTÊMICAS E BUCAIS ........................................................... 78

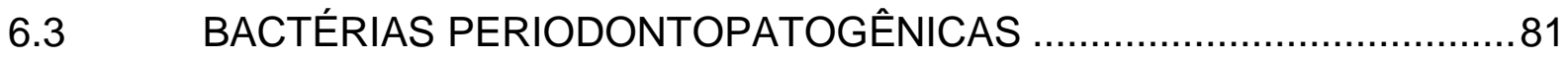

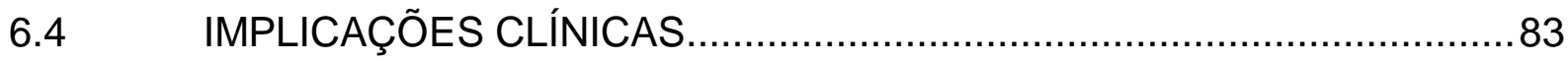

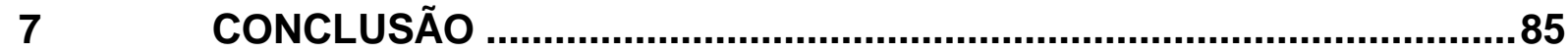

REFERÊNCIAS ........................................................................... 89

APÊNDICE ................................................................................... 103

ANEXOS ......................................................................................... 111 

1 Introdução 



\section{INTRODUÇÃO}

O perfil nutricional das populações vem sofrendo modificações com significante aumento da obesidade, tanto em países desenvolvidos quanto em países em desenvolvimento, sendo considerada como "a epidemia do século XXI" (KOPELMAN, 2000). O impacto da obesidade na morbimortalidade, por desencadear doenças cardiovasculares, diabetes tipo 2, hipertensão arterial, osteoartrite, síndrome de apnéia do sono, entre outras, representa um considerável problema de saúde pública (KOPELMAN, 2000).

A obesidade também predispõe o indivíduo a problemas bucais como a doença periodontal (BASTOS et al., 2005; RITCHIE, 2007), erosão dentária relacionada ao refluxo gastroesofágico (BARRON et al., 2003; BICCAS et al., 2009), cárie dentária (TRAEBERT et al., 2004) e xerostomia (MODEER et al., 2010). Como existe uma relação sinérgica entre nutrição e saúde bucal (TOUGER-DECKER; MOBLEY, 2007), a atuação multiprofissional torna-se fundamental na promoção da saúde, prevenção e intervenção de doenças.

O tratamento da obesidade mórbida pode ser feito através da cirurgia bariátrica por um mecanismo que leva à restrição ou à má-absorção dos alimentos consumidos e tem se mostrado eficaz (MADAN et al., 2006). O número de cirurgias da obesidade tem aumentado nos últimos anos (ZHAO; ENCINOSA, 2006) e o seu sucesso está pautado na efetiva perda de peso, no controle das comorbidades e no aumento da qualidade de vida (ARASAKI et al., 2005; BOULDIN et al., 2006; CENEVIVA et al., 2006; MAGDALENO et al., 2009; SHIKORA; KIM; TARNOFF, 2007).

No entanto, algumas consequências negativas também têm sido relatadas, tais como, hiperparatireoidismo e osteoporose (NEED et al., 2004; TSIFTSIS et al., 2009; VALDERAS et al., 2009; WILLIAMS et al., 2008), regurgitação crônica (ARASAKI et al., 2005), deficiências nutricionais (BALSA et al., 2008; BRETON et al., 2005; MADAN et al., 2006; MALINOWSKI, 2006; WILLIAMS et al., 2008) e problemas bucais (DE MOURA-GREC et al., 2012; HAGUE; BAECHLE, 2008; HELING et al., 2006; MARSICANO, 2008; MARSICANO et al., 2011; SILVA, 2008).

O aumento na severidade da doença periodontal, do desgaste dentário, da incidência de cárie e do bruxismo são os problemas bucais que têm sido observados 
em pacientes submetidos à cirurgia da obesidade (HAGUE; BAECHLE, 2008; HELING et al., 2006; MARSICANO et al., 2011; PATARO et al., 2011). Os possíveis fatores envolvidos para a ocorrência desses problemas incluem a má absorção de nutrientes devido às alterações anatômicas no trato gastrointestinal (RUBIO; MORENO, 2007), mudança significante nos hábitos alimentares (MALINOWSKI, 2006) e ocorrência de vômitos frequentes (ELDER; WOLFE, 2007).

A má-absorção de cálcio como efeito colateral da cirurgia bariátrica pode desencadear osteoporose (DEITEL, 2010) e consequentemente refletir na cavidade bucal com perda óssea alveolar (DE MOURA-GREC et al., 2012) e posterior perda dentária (NICOPOULOU-KARAYIANNI et al., 2009).

A interface entre a doença periodontal e a obesidade (RITCHIE, 2007) ou o pós-operatório da cirurgia bariátrica (DE MOURA-GREC et al., 2012; MARSICANO et al., 2011) proporciona questionamentos sobre como bactérias periodontopatogências, tais como Porphyromonas gingivalis, Tannerella forsythia, Treponema denticola, e Prevotella intermedia exercem influência sobre o periodonto de pacientes obesos e bariátricos.

Tendo em vista o aumento na prevalência da obesidade e a crescente realização de cirurgias para redução de peso (BUCHWALD; WILLIAMS, 2004; KOPELMAN, 2000; ZHAO; ENCINOSA, 2006), torna-se relevante identificar os problemas bucais que acometem esse grupo populacional para possibilitar elaboração de estratégias de intervenção e prevenção a fim de reduzir os possíveis agravos à saúde bucal e manter os benefícios sistêmicos alcançados com a redução do excesso de peso corporal. Além disso, estudos que abordam este tema, principalmente doença periodontal e quantificação de bactérias periodontopatogênicas em pacientes bariátricos, são escassos. 


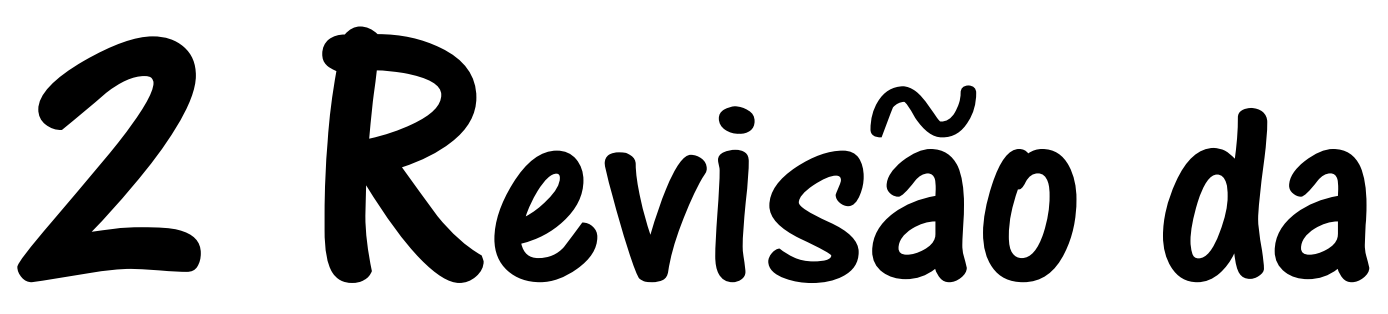

Literatura 



\section{REVISÃO DA LITERATURA}

\subsection{OBESIDADE}

A obesidade é uma doença crônica caracterizada pelo acúmulo excessivo de gordura corporal (WHO, 1998). A Organização Mundial da Saúde adotou, após a reunião de 1997, o sistema baseado na medição do Índice de Massa Corporal (IMC) para detectar a obesidade, obtido pelo cálculo da relação entre peso corpóreo $(\mathrm{kg})$ e o quadrado da altura $\left(\mathrm{m}^{2}\right)$. IMC maior ou igual a 25 caracteriza sobrepeso e IMC maior ou igual a 30 caracteriza obesidade (grau I: situa-se entre 30 a $34,99 \mathrm{Kg} / \mathrm{m}^{2}$, grau II: entre 35 a $39,99 \mathrm{Kg} / \mathrm{m}^{2}$, e grau III: acima de $\left.40 \mathrm{Kg} / \mathrm{m}^{2}\right)(\mathrm{WHO}, 1998)$. A Sociedade Americana de Cirurgia Bariátrica classifica a obesidade em 6 níveis: Obesidade Pequena $\left(27<30 \mathrm{Kg} / \mathrm{m}^{2}\right)$, Obesidade Moderada $\left(30<35 \mathrm{Kg} / \mathrm{m}^{2}\right)$, Obesidade Grave $\left(35<40 \mathrm{Kg} / \mathrm{m}^{2}\right)$, Obesidade Mórbida $\left(40<50 \mathrm{Kg} / \mathrm{m}^{2}\right)$, Super Obesidade $\left(50<60 \mathrm{Kg} / \mathrm{m}^{2}\right)$ e Super-Super Obesidade $\left(\geq 60 \mathrm{Kg} / \mathrm{m}^{2}\right)$ (RENQUIST, 1998).

O crescimento da obesidade tanto em países desenvolvidos quanto em desenvolvimento foi considerado alarmante, sendo um dos problemas contemporâneos de saúde mais negligenciados em todo mundo (KOPELMAN, 2000). Há uma epidemia mundial estimada em 1,7 bilhões de pessoas com sobrepeso e obesidade e 2,5 milhões de mortes por ano atribuídas à obesidade (BUCHWALD; WILLIAMS, 2004).

Nos Estados Unidos a prevalência de obesidade em adultos é de 35,5\% em mulheres e 32,2\% em homens (FLEGAL et al., 2010). Já na Europa a obesidade atinge de 10 a $20 \%$ dos homens e de 15 a $25 \%$ das mulheres, sendo que a prevalência de sobrepeso já atinge metade da população (JAMES; RIGBY; LEACH, 2004).

O Instituto Brasileiro de Geografia e Estatística (IBGE) divulgou dados sobre a prevalência de excesso de peso e obesidade na população brasileira com 20 anos de idade ou mais no período de 2008/2009. Entre os homens a prevalência de excesso de peso foi de $50,1 \%$ e de obesidade $12,4 \%$. Já entre as mulheres, a proporção de excesso de peso foi de $48 \%$ e de obesidade 16,9\%. Em 30 anos a 
obesidade cresceu mais de quatro vezes entre os homens e mais de duas vezes entre as mulheres (IBGE, 2010).

A obesidade está associada a algumas das mais prevalentes doenças crônicas e não infecciosas na sociedade moderna. Dentre essas comorbidades podem-se citar diabetes mellitus tipo 2, hipertensão arterial, dislipidemia, arteriosclerose, artrite, síndrome de apnéia do sono, refluxo gastresofágico, infertilidade e incontinência urinária em mulheres, disfunções endócrinas, disfunção da vesícula biliar, problemas pulmonares, alguns tipos de câncer, doença periodontal, falta de habilidade para atividades diária, problemas psicossociais e econômicos (DE FRANCISCHI et al., 2000; KOPELMAN, 2000; RITCHIE, 2007).

\subsection{OBESIDADE E SAÚDE BUCAL}

Indivíduos com sobrepeso e obesidade possuem maior risco para sintomas de refluxo (TAl et al., 2010), que pode refletir na saúde bucal, causando desgaste dentário por erosão do esmalte (MOAZZEZ; BARTLETT; ANGGIANSAH, 2004). Além disso, a obesidade, aliada à falta de exercícios físicos e à baixa auto-estima, predispõe o indivíduo à ansiedade (ATLANTIS; GOLDNEY; WITTERT, 2009) que por sua vez pode se manifestar com episódios de bruxismo, levando à ocorrência de desgaste dentário por atrição (SUTIN et al., 2010).

O desgaste dentário pode ser definido como a perda gradual de estrutura dos dentes, não cariosa, devido a fatores mecânicos ou químicos. O termo desgaste dentário deve ser considerado abrangente para descrever o processo combinado de perda de estrutura dos dentes por atrição, abfração, abrasão e erosão (GRIPPO; SIMRING, 1995; PEGORARO et al., 2005). A atrição é a perda de estrutura dentária causada pelo contato dente a dente, atingindo principalmente a face oclusal/incisal, como observada em pacientes com bruxismo (hábito de ranger os dentes) (LITONJUA et al., 2003). Na abfração a perda de estrutura dentária ocorre na região cervical como resultado de forças oclusais (GRIPPO, 1991). A abrasão é o desgaste causado por processos mecânicos extrínsecos, como a própria escovação, sendo a face vestibular mais frequentemente afetada (LEVITCH et al., 1994). A erosão é a perda progressiva da estrutura dentária por processo químico, pela ação de ácidos de origem extrínseca ou intrínseca e não bacteriana, comumente observada nas superfícies linguais/palatinas (BARRON et al., 2003; LITONJUA et al., 2003). 
A saliva tem importante papel na fisiologia esofageana, na digestão e na proteção das células gástricas, participa efetivamente na mastigação, fala, deglutição, sensibilidade gustativa, lubrificação dos tecidos, proteção das mucosas contra a invasão de diversas substâncias, na atividade antibacteriana, antifúngica e antivirótica, maturação pós-eruptiva e regulação do balanço iônico na remineralização do esmalte, deposição da película adquirida e limitação da difusão de ácidos (FENOLL-PALOMARES et al., 2004). É uma das principais responsáveis pela manutenção da homeostase bucal, contribuindo para a estabilidade do $\mathrm{pH}$ e flora oral (ITO et al., 2008). Assim, a função da saliva é um fator importante na etiologia de doenças bucais como doença periodontal, erosão e cárie dentária (TOGASHI; MONTANHA; TÁRZIA, 1998). A secura bucal conhecida como xerostomia pode ser um reflexo de uma descompensação diabética, ou também por administração de alguns antidepressivos (VON BULTZINGSLOWEN et al., 2007), comumente administrados em obesos (VASQUES; MARTINS; AZEVEDO, 2004).

O tecido adiposo secreta grande quantidade de citocinas pró-inflamatórias e os níveis dessas são proporcionais ao índice de massa corporal, principalmente em indivíduos com obesidade visceral (VGONTZAS et al., 1997). As citocinas inflamatórias estimulam a produção da proteína C-reativa no fígado que tem a capacidade de interagir com componentes da membrana de microorganismos, tendo seus níveis séricos aumentados em condições inflamatórias (VGONTZAS et al., 1997). Diversas pesquisas têm sido realizadas para elucidar a associação entre obesidade e concentrações de proteína C-reativa (BRASIL et al., 2007; COOK et al., 2000; KOPP et al., 2003). Existe ainda uma relação positiva entre doença periodontal e nível sérico elevado de proteína C-reativa, uma vez que na periodontite as citocinas e os mediadores inflamatórios estão significativamente elevados (MARIOTTI, 2004; MONTEBUGNOLI et al., 2004). Diante disto, a obesidade na hiperindução das citocinas pode promover o processo inflamatório crônico das estruturas periodontais (EBERSOLE et al., 1997).

Doença periodontal pode ser definida como uma alteração patológica, de caráter inflamatório, provocada pelo acúmulo de placa bacteriana, atingindo os tecidos gengivais (gengivite), que pode ou não progredir para destruição dos tecidos de suporte dentário (periodontite), sendo a principal causa de perda dentária em adultos (RIEP et al., 2009). No entanto, nem todos pacientes são igualmente suscetíveis à periodontite (PISCHON et al., 2007). Além do desafio microbiano, 
fatores genéticos, ambientais e sistêmicos desempenham um papel na patogênese da doença (PAGE; KORNMAN, 1997).

Em um estudo para investigar a associação da composição corporal e a doença periodontal, em indivíduos caucasianos com mais de 18 anos, os autores puderam concluir que existe uma forte correlação positiva entre a obesidade abdominal e a doença periodontal (WOOD; JOHNSON; STRECKFUS, 2003). A influência da obesidade sobre a incidência da doença periodontal foi analisada em um estudo populacional com 13.665 jovens adultos norte-americanos, submetidos ao exame periodontal. Os resultados revelaram uma associação significativa entre a obesidade e a ocorrência da doença periodontal em jovens adultos (18-34 anos) e os autores concluíram que a obesidade precoce em indivíduos de 18 a 34 anos de idade pode ser considerada como um fator de risco em potencial para a doença periodontal (AL-ZAHRANI; BISSADA; BORAWSKIT, 2003).

A importância da redução da obesidade para a saúde pública e para a qualidade de vida de pessoas obesas indica que estudos rigorosos sobre a prevenção e o tratamento da obesidade e de seus agravos são essenciais. $O$ tratamento clínico da obesidade envolve várias abordagens, como a dieta de restrição calórica, a prática de exercícios físicos e uso de medicamentos (DE FRANCISCHI et al., 2000). Entretanto, vários pacientes não respondem a estas estratégias terapêuticas, necessitando de uma intervenção mais eficaz por meio do procedimento cirúrgico, denominado cirurgia bariátrica, que é feito por um mecanismo de restrição e/ou má-absorção dos alimentos ingeridos, com a redução do reservatório gástrico (BUCHWALD, 2005; BUCHWALD; WILLIAMS, 2004).

\subsection{CIRURGIA BARIÁTRICA}

A indicação da cirurgia baseia-se numa análise abrangente de múltiplos aspectos do paciente. O principal critério é possuir $I M C \geq 40 \mathrm{~kg} / \mathrm{m}^{2}$ ou $\mathrm{IMC} \geq 35$ $\mathrm{kg} / \mathrm{m}^{2}$ na presença de comorbidades como hipertensão, diabetes melittus tipo 2, apnéia do sono, dislipidemia, entre outras (BROLIN, 2002; BUCHWALD, 2005; ELDER; WOLFE, 2007). Os critérios importantes para a seleção do paciente são: quando métodos menos invasivos para perda de peso não demonstraram resultados e o paciente apresenta um alto risco de morbidade ou mortalidade relacionado à obesidade, ausência de distúrbios endócrinos, estabilidade psicológica, ausência de 
abuso de álcool e drogas, ausência de pneumopatias graves, de insuficiência renal, de lesão acentuada do miocárdio e de cirrose hepática (BROLIN, 2002; FANDIÑO et al., 2004).

A cirurgia bariátrica é classificada em restritiva, disabsortiva e mista, que é a combinação de ambas (BROLIN, 2002; ELDER; WOLFE, 2007; KORENKOV; SAUERLAND; JUNGINGER, 2005). Procedimentos restritivos como a banda gástrica ajustável ou a gastroplastia limitam a ingestão calórica pela diminuição do reservatório gástrico, enquanto os disabsortivos diminuem a capacidade de absorção intestinal com a exclusão de parte do intestino, como na derivação biliopancreática (BROLIN, 2002; KORENKOV; SAUERLAND; JUNGINGER, 2005). Nos últimos anos a técnica mista é a que mais tem sido utilizada, conhecida como derivação gastrojejunal em $Y$ de Roux (BUCHWALD et al., 2004) (FIGURA 1) que consiste na restrição do estômago a um volume de 20 a $30 \mathrm{ml}$ cujo compartimento recebe uma conexão (em formato de $Y$ ) com uma alça do jejuno, sendo o duodeno totalmente desviado (BROLIN, 2002). A cirurgia bariátrica que combina a derivação gastrojejunal em $Y$ de Roux com um anel de contenção (banda) na saída do "estômago reduzido" é conhecida como Fobi-Capella (CAPELLA et al., 1991; FOBI, 2005).

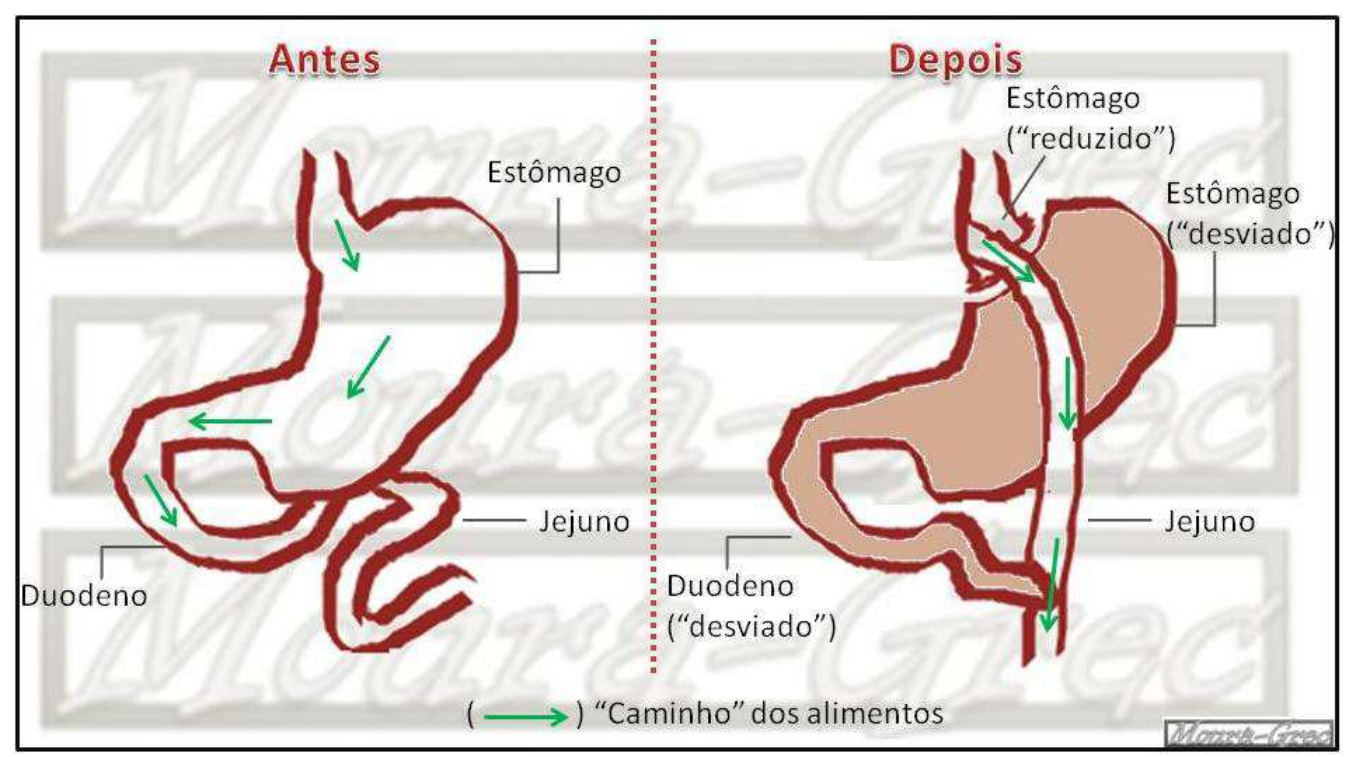

Fonte: Moura-Grec, PG, 2012.

Figura 1 - Derivação gastrojejunal em Y-de-Roux

Os resultados esperados com a derivação gastrojejunal em Y-de-Roux incluem: perda e manutenção do peso corporal e melhora das comorbidades 
associadas e da qualidade de vida (FANDIÑO et al., 2004; SEARS et al., 2008). Por outro lado, há diversas complicações pós-operatórias que merecem especial atenção como vômitos frequentes e deficiências nutricionais (ELDER; WOLFE, 2007; FANDIÑO et al., 2004; MALINOWSKI, 2006) que podem refletir na saúde bucal.

\subsection{COMPLICAÇÕES SISTÊMICAS E BUCAIS DA CIRURGIA BARIÁTRICA}

O risco de ocorrer refluxo gastroesofágico é maior conforme aumenta o valor do IMC a partir do sobrepeso (EL-SERAG; SATIA; RABENECK, 2005), mas também, após a cirurgia bariátrica, alguns pacientes podem desenvolver regurgitação crônica decorrente do diâmetro estreito do anel de silicone e da hipotonia do esfíncter esofágico (ARASAKI et al., 2005; BELAFSKY et al., 2008). A ocorrência de refluxo gastroesofágico reflete na saúde bucal, causando desde a erosão do esmalte até lesões erosivas na mucosa oral (BARRON et al., 2003; CEBRIAN-CARRETERO; LOPEZ-ARCAS-CALLEJA, 2006; MOAZZEZ; BARTLETT; ANGGIANSAH, 2004).

A erosão dentária é um tipo de lesão não cariosa que se desenvolve como consequência da perda de estrutura dentária causada por ação química, sem o envolvimento de bactérias e pode ter origem intrínseca ou extrínseca (SCHEUTZEL, 1996; TEN CATE; IMFELD, 1996). Os fatores causadores extrínsecos são: dieta (frutas, bebidas ácidas), meio ambiente (indústrias químicas, piscinas cloradas) e medicamentos (vitamina C, aspirina, ácido clorídrico) (TEN CATE; IMFELD, 1996). Os fatores intrínsecos são: doenças que provocam regurgitação do suco gástrico ou diminuição do fluxo salivar (SCHEUTZEL, 1996; SOBRAL et al., 2000).

Um estudo foi realizado com a finalidade de avaliar as condições da saúde bucal de pacientes que apresentavam refluxo gastroesofágico, sendo encontrada maior incidência de erosão dentária, aftas, ardência bucal, sensibilidade dentinária e gosto azedo e menor incidência de lesões cariosas nestes pacientes (CORREA; LERCO; HENRY, 2008). Problemas gástricos como vômitos recorrentes, anorexia, bulimia, regurgitação gastrointestinal, baixo fluxo salivar associado com alto consumo de comidas ácidas podem também ter relação com erosão (ECCLES; JENKINS, 1974).

Após a cirurgia bariátrica, com a redução do estômago, é necessário que 0 paciente tenha uma alimentação em menor quantidade, maior frequência e mais 
prolongada durante o dia, ou seja, há a necessidade de uma mudança radical nos hábitos alimentares desse indivíduo (MALINOWSKI, 2006; PARKES, 2006). Sendo assim, o fato de o paciente ter que comer mais vezes ao dia faz com que bactérias causadoras de doenças da boca ficam em condições favoráveis, necessitando de uma atenção especial com a higienização para evitar problemas bucais (HAGUE; BAECHLE, 2008).

Um estudo realizado em três hospitais de Jerusalém aplicou um questionário sobre a saúde bucal em 113 pacientes, com idade média de 40 anos, com 4 a 5 anos de pós-operatório de cirurgia bariátrica e observaram que $37 \%$ dos pacientes estavam comendo mais doce após a cirurgia, apenas $20 \%$ afirmaram ter melhorado a higiene bucal e 37\% relataram aumento de hipersensibilidade dentinária. Houve uma significante associação com relato de hipersensibilidade dentinária e vômitos. Os problemas dentários percebidos após a cirurgia bariátrica, devem ser considerados para a elaboração de informações e instruções sobre cuidados com a saúde bucal (HELING et al., 2006).

No Brasil, pacientes obesos indicados à cirurgia bariátrica $(n=50)$ e pacientes já submetidos à cirurgia $(n=52)$ no Hospital das Clínicas de Ribeirão Preto, foram comparados quanto à prevalência de desgaste dentário e de doença periodontal. $\mathrm{O}$ grupo de operados apresentou maior severidade de doença periodontal em relação ao grupo de obesos (MARSICANO, 2008). Outro estudo transversal sobre as consequências da cirurgia bariátrica na saúde bucal, conduzido em Belo Horizonte, também encontrou maior prevalência de periodontite no grupo pós-operatório de até 6 meses, sendo $91,7 \%$ enquanto que no grupo pré-cirurgia foi de 70,7\% (PATARO et al., 2011).

A avaliação da saúde bucal de pacientes atendidos em Ribeirão Preto no précirúrgico, 3 e 6 meses após cirurgia bariátrica consistiu no primeiro estudo longitudinal publicado sobre a interface entre cirurgia bariátrica e saúde bucal. Este estudo observou maior incidência e aumento na severidade do desgaste dentário e da doença periodontal após 3 meses de cirurgia (MARSICANO et al., 2011).

A má absorção de macro e micronutrientes é uma sequela frequente em pacientes submetidos à cirurgia bariátrica, em particular à derivação gastrojejunal em Y de Roux (MALINOWSKI, 2006). A ocorrência disso se dá por causa da dieta restritiva adotada posteriormente e das alterações nas características anatômicas do trato gastrointestinal devido ao ato cirúrgico, reduzindo o volume de ingestão de 
alimentos e podendo alterar as características dos nutrientes ingeridos (RUBIO; MORENO, 2007).

As deficiências de micronutrientes mais comuns associados com RYGB são deficiências de ferro, vitamina B12, cálcio e vitamina $D$, que podem levar a sérias consequências como hiperparatiroidismo, osteoporose e osteopenia (MALINOWSKI, 2006). Assim, a doença metabólica óssea é um fator de risco em longo prazo após cirurgia bariátrica (DE PRISCO; LEVINE, 2005; MALINOWSKI, 2006). Outras complicações pós-operatórias encontradas foram hipocalcemia em 23,8\% e hiperparatiroidismo secundário em $45,4 \%$ dos casos. Todas essas complicações foram mais frequentes em pacientes que passaram pela derivação biliopancreática (BRETON et al., 2005).

Balsa et al.(2008) realizaram um estudo transversal com 72 pacientes que se submeteram a derivação biliopancreática de abril de 2007 a outubro de 2007. O estudo demonstrou que $80 \%$ dos pacientes obesos, submetidos à cirurgia de redução tinham níveis séricos de vitamina $D$ inferiores a $32 \mathrm{mg} / \mathrm{mL}$ (BALSA et al., 2008). Silva et al.(2008) avaliaram 180 pacientes com deficiência de Vitamina $D$ e foi encontrado osteoporose em $26,3 \%$ dos casos (SILVA et al., 2008).

A vitamina $D$ é essencial para manter o metabolismo do cálcio normal. $\mathrm{Na}$ deficiência desta vitamina a absorção de cálcio é insuficiente, podendo levar ao hiperparatiroidismo secundário (FLEET et al., 2008; NEED et al., 2004; REGINSTER, 2005; SAHOTA et al., 2004; STAUD, 2005), que é o aumento da produção do hormônio da paratireóide (PTH), além da retirada do cálcio dos ossos e da reabsorção nos rins para manter os níveis normais de cálcio.

A perda óssea associada à cirurgia bariátrica foi observada por Fleischer et al. (2008) que avaliaram 23 obesos, homens e mulheres, de 20 a 64 anos. Os resultados mostraram uma diminuição da densidade óssea mineral do colo femoral $(9,2 \%)$ e no quadril $(8,0 \%)$ associada à extensão da perda de peso (FLEISCHER et al., 2008). Quanto à saúde bucal, se o tecido ósseo da maxila e mandíbula for afetado, poderá levar a perda dentária por comprometimento do periodonto de sustentação. Em um relato de caso, a paciente submetida à cirurgia bariátrica foi acompanhada por 2 anos, sendo diagnosticado aumento da perda óssea alveolar entre o primeiro e o segundo ano após cirurgia por meio de tomografia computadorizada de feixe cônico (cone beam). Foi verificado clinicamente um 
aumento da profundidade de bolsa periodontal de quase $1 \mathrm{~mm}$ durante o período do estudo (DE MOURA-GREC et al., 2012).

Portanto, de acordo com o sugerido em diversos estudos (MALINOWSKI, 2006; OLIVEIRA; LINARDI; AZEVEDO, 2004; TUCKER; SZOMSTEIN; ROSENTHAL, 2007), o aconselhamento e o monitoramento nutricional, além da suplementação de vitaminas e minerais, devem ser empregados para esses pacientes na prevenção e no tratamento das consequências metabólicas advindas da cirurgia bariátrica.

\subsection{BACTÉRIAS PERIODONTOPATOGÊNICAS}

A superfície dentária é colonizada predominantemente por microorganismos aeróbios, Gram-positivos facultativos e aderidos ao biofilme dentário, que formam os complexos amarelo, verde e roxo, os quais não estão diretamente relacionados à doença periodontal (SOCRANSKY et al., 1998). Porém, a retenção do biofilme microbiano à margem gengival leva à quebra do equilíbrio da relação microbiotahospedeiro (CURTIS; SLANEY; ADUSE-OPOKU, 2005), iniciando uma reação inflamatória. Com o ambiente favorável, privado de oxigênio, ocorre a proliferação das bactérias anaeróbias e Gram-negativas do complexo laranja (Fusobacterium nucleatum, Prevotella intermedia, Prevotella nigrescens), que por sua vez, precede ao aparecimento do complexo vermelho ( $P$. gingivalis, $T$. forsythia e $T$. denticola), ocasionando a destruição dos tecidos periodontais (SOCRANSKY et al., 1998).

Os parâmetros de profundidade de sondagem, sangramento gengival e nível de inserção clínica têm mostrado relação direta com a presença das espécies do complexo vermelho e, em certa extensão, do complexo laranja (SOCRANSKY et al., 1998).

$P$. gingivalis é considerada uma das bactérias mais frequentes em placas subgengivais em indivíduos com doença periodontal (TAMURA et al., 2005). A presença dessa bactéria tem sido associada com perda óssea alveolar, bolsas profundas e perda de inserção clínica nos portadores de periodontite crônica (CHAVES et al., 2000).

As bactérias $T$. forsythia e $T$. denticola têm se mostrado em maior número quanto mais profunda a bolsa periodontal em pacientes com periodontite severa (SAKAMOTO et al., 2002; YOSHIDA et al., 2004). 
A $P$. intermedia é fermentadora de carboidratos, podendo ser encontrada na gengivite e na periodontite avançada (ASHIMOTO et al., 1996). Embora essa bactéria seja do complexo laranja, tem sido correlacionada com $P$ gingivalis e $T$. forsythia, indicando uma relação simbiótica entre esses microrganismos no interior de bolsas periodontais (ASHIMOTO et al., 1996).

A $P$. gingivalis e a $P$. intermedia foram identificadas em placas ateromatosas, que podem ter sido conduzidas pelo sangue instalando-se nas paredes vasculares, formando o elo entre a doença periodontal e complicações cardíacas (HARASZTHY et al., 2000).

Alta prevalência de $T$. forsythia em pacientes com periodontite agressiva generalizada $(95 \%)$, de $P$. gingivalis e de $P$. intermedia em pacientes com periodontite crônica ( $76 \%$ e $74 \%$, respectivamente) foi encontrada no estudo de Riep et al. (2009). A T. denticola foi altamente associada com as duas situações (RIEP et al., 2009). Essas bactérias também foram detectadas em indivíduos sem doença periodontal, mas em menor quantidade, sugerindo que se trata de patógenos oportunistas (RIEP et al., 2009).

No estudo conduzido por Brennan et al. (2007) com mulheres pós menopausa avaliou-se a prevalência dos patógenos periodontais $T$. forsythia, $P$. gingivalis, $P$. intermedia e $C$. rectus e observou-se associação da presença destes com o IMC das participantes e com a perda óssea alveolar, e ainda, encontraram nas mulheres com sobrepeso e infecção por $T$. forsythia maior perda óssea alveolar do que as mulheres com peso normal ou obesas com infecção por $T$. forsythia (BRENNAN et al., 2007).

Pataro (2010) observou maior frequência dos periodontopatógenos do complexo vermelho em indivíduos submetidos à cirurgia bariátrica do que em obesos, sendo a T.forsythia a mais frequente delas (PATARO, 2010). Diante desses achados, o autor sugeriu o monitoramento longitudinal desses pacientes devido ao papel dessas bactérias na progressão da doença periodontal.

Diante do exposto, as alterações anatômicas no trato gastrointestinal parecem desencadear consequências sistêmicas importantes que podem repercutir na cavidade bucal, incluindo desequilíbrio na sua microbiota. 
30 bjetivos 



\section{OBJETIVOS}

\subsection{OBJETIVO GERAL}

O objetivo deste estudo longitudinal foi avaliar o impacto da cirurgia bariátrica na condição periodontal e quantificar bactérias periodontopatogênicas em pacientes submetidos a esta cirurgia.

\subsection{OBJETIVOS ESPECÍFICOS}

- Identificar, antes e após cirurgia, a prevalência dos problemas bucais: hipossalivação, desgaste dentário e doença periodontal;

- Identificar por meio do prontuário do paciente, variáveis sistêmicas (proteína C-reativa, cálcio, PTH, diabetes) e investigar eventual associação com problemas bucais;

- Analisar a autopercepção quanto à saúde bucal e investigar eventual associação com problemas bucais e também com a perda de peso;

- Comparar as condições bucais de pacientes obesos com um grupo controle de pacientes com IMC normal;

- Detectar e quantificar bactérias periodontopatogênicas ( $P$. gingivalis, $T$. forsythia, $T$. denticola e $P$. intermedia) e investigar eventual associação à obesidade (IMC) e ao tempo de pós-operatório. 



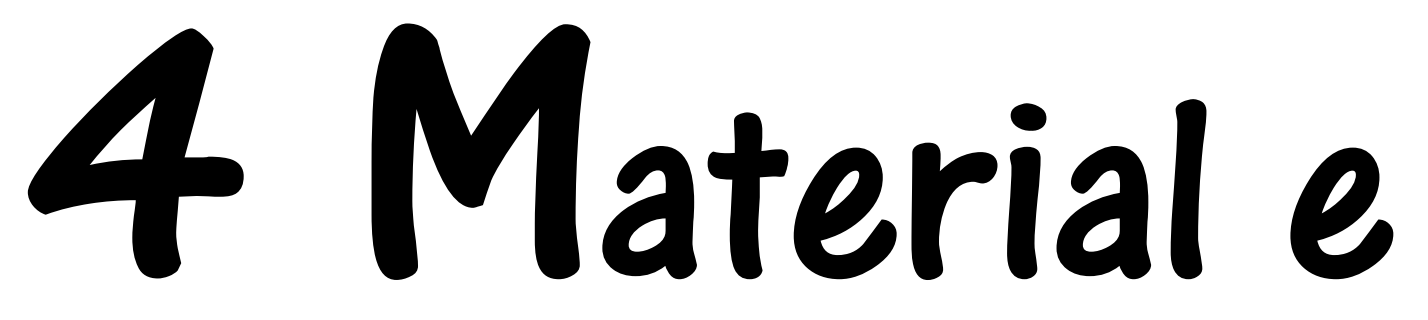

Métodos 



\section{MATERIAL E MÉTODOS}

\subsection{ASPECTOS ÉTICOS}

Este projeto foi encaminhado aos Comitês de Ética em Pesquisa com Seres Humanos (CEP) de cada hospital em que foi obtida a amostra (Quadro 1), tendo sido aprovado (ANEXOS A, B e C). Os pacientes foram selecionados para a análise após a aprovação pelos Comitês e receberam explicação minuciosa dos objetivos da pesquisa a partir de uma leitura da Carta de Esclarecimento ao Paciente e assinatura do Termo de Consentimento Livre e Esclarecido (APÊNDICE A).

\begin{tabular}{|l|l|c|}
\hline CEP & Parecer APROVADO & ANEXOS \\
\hline HB/FAMERP & № 315/08 & A \\
\hline HC/FMB & № 468/08 & B \\
\hline HC/HCRP & № 12384/09 & C \\
\hline
\end{tabular}

Quadro 1 - Números dos protocolos de aprovação dos Comitês de Ética

\subsection{DELINEAMENTO DO ESTUDO}

Trata-se de um estudo longitudinal prospectivo, composto pelas seguintes etapas: a) calibração do examinador; b) aplicação de questionário, avaliação de fluxo salivar e exame clínico - desgaste dentário e condição periodontal; c) coleta do fluido gengival; d) detecção e quantificação de bactérias periodontopatogênicas; e) reavaliação (b,c,d) de 6 e 12 meses após cirurgia bariátrica (FIGURA 2).
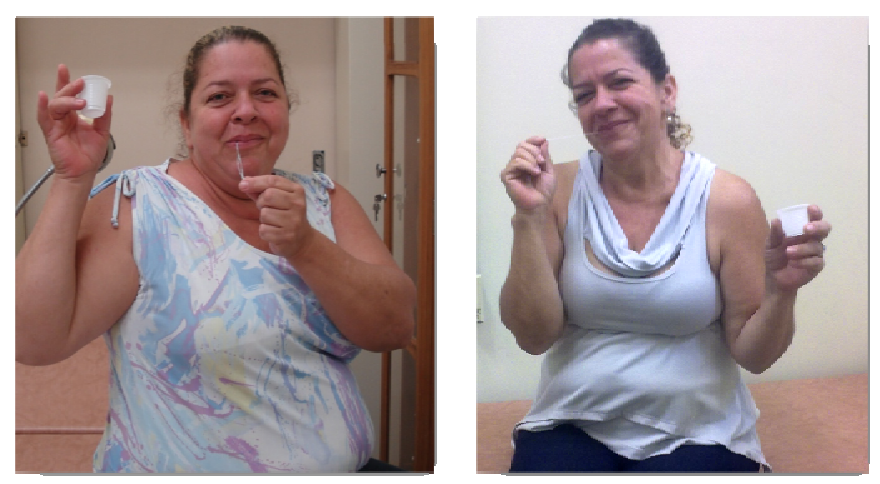

Figura 2 - Paciente avaliada antes e após a cirurgia bariátrica (com permissão-ANEXO D) 


\subsection{CALIBRAÇÃO DA EXAMINADORA}

A examinadora participou do processo de calibração como atividade da disciplina de Epidemiologia oferecida pela pós-graduação da Faculdade de Odontologia de Bauru - FOB/USP. O processo de calibração foi conduzido por um examinador padrão, experiente em levantamentos epidemiológicos. No primeiro período de treinamento (4h) foi ministrada aula teórica, buscando a padronização inicial quanto aos códigos, critérios e condutas de exames adotados no estudo. Em seguida, foram desenvolvidos exercícios, iniciando pela exposição visual de casos clínicos por parte do examinador padrão, avaliando e discutindo as condições de saúde bucal, que seriam observadas no trabalho de campo. A calibração propriamente dita ocorreu em um período de $4 \mathrm{~h}$, em que indivíduos foram examinados e após a coleta dos dados houve uma discussão geral dos casos para se certificar de que a examinadora estaria familiarizada com os procedimentos (SALES-PERES, 2008). Para avaliar a concordância intraexaminadora foram reexaminados 30 indivíduos, durante um levantamento epidemiológico (atividade da disciplina de Epidemiologia), para calcular o Kappa para desgaste dentário e quatro pacientes desta pesquisa (o que corresponde a 144 sítios avaliados) para calcular o teste $t$ pareado para profundidade de sondagem periodontal. O valor do kappa obtido para avaliação do desgaste dentário foi de 0,82 considerada concordância quase perfeita (LANDIS; KOCH, 1977). A diferença entre as médias da profundidade de sondagem foi de $0,01 \mathrm{~mm}$, não significativa $(p=0,746)$, indicando a concordância intraexaminadora.

\subsection{COMPOSIÇÃO DA AMOSTRA E ESTUDO PILOTO}

\subsubsection{Pacientes bariátricos}

A amostra foi composta por pacientes indicados à cirurgia bariátrica pela derivação gastrojejunal em $Y$ de Roux (GBRY), com ou sem anel, atendidos nos seguintes hospitais: Hospital de Base - Faculdade de Medicina de São José do Rio Preto (HB/FAMERP), Hospital das Clínicas de Botucatu - UNESP (HC/FMB-UNESP) e Hospital das Clínicas de Ribeirão Preto - Universidade de São Paulo (HCRP/FMRP-USP). Como eram realizadas no máximo duas cirurgias por semana, 
optou-se por realizar a coleta nestes 3 hospitais de referência em cirurgia bariátrica e ligados a faculdades de medicina no Estado de São Paulo, para que fosse possível obter a amostra proposta que seria inicialmente 90 pacientes, cerca de 30 por hospital.

Os primeiros 16 pacientes avaliados após 6 meses de cirurgia constituíram o estudo piloto para a verificação das estratégias propostas, que possibilitou realizar o cálculo amostral.

O cálculo do tamanho da amostra para a diferença de duas médias foi realizado utilizando-se o software GPower versão 3.1 (Heinrich-Heine-University, Düsseldorf, Germany), considerando o poder do teste de $80 \%$ e o coeficiente de confiança de $95 \%$. Os valores referentes ao desvio padrão das variáveis das condições bucais, necessários para realizar o cálculo amostral, foram obtidos dos resultados do estudo piloto. Os valores para o tamanho da amostra variaram de 5 a 38 indivíduos. Assim, considerou-se a variável que obteve o maior tamanho amostral, que era a variável "\% de sítios com bolsa 4-5 mm", utilizando como mínima diferença a ser detectada de $2 \%$ (que corresponde a incidência de 3 sítios). Portanto, optou-se por manter o $\mathrm{n}=90$ para a amostra inicial considerando-se as possíveis perdas durante a pesquisa, uma vez que se trata de um estudo longitudinal prospectivo composto de mais 2 avaliações.

Os critérios de exclusão foram: 1) não aceitar participar; 2) possuir menos de 6 dentes; 3) estar fazendo uso de medicamentos antibióticos, anti-inflamatórios e imunossupressores que pudessem mascarar os dados da coleta; 4) gestante.

\subsubsection{Pacientes não obesos (grupo controle)}

Para fins de comparação das condições de saúde bucal entre obesos e não obesos no baseline, foram coletados os dados obtidos em duas pesquisas desenvolvidas paralelamente pela mesma examinadora, com a mesma metodologia para avaliação bucal, autopercepção e avaliação antropométrica. A amostra controle foi composta por 51 indivíduos com IMC normal, sendo 37 mulheres participantes da pesquisa "Estado nutricional e problemas bucais em mulheres: impacto na qualidade de vida", aprovada pelo Comitê de Ética em Pesquisa da FOB/USP (№194/2009) e 14 homens participantes do grupo controle da pesquisa "Avaliação da função autonômica cardiovascular, inflamação sistêmica e capacidade aeróbica em 
indivíduos com diabetes mellitus tipo 2" aprovada pelo Comitê de Ética em Pesquisa da Universidade Federal de São Carlos (№093/2011).

\subsection{DADOS DO PARTICIPANTE E INFORMAÇÕES COMPLEMENTARES (APÊNDICE B)}

Dados de identificação foram preenchidos pelos próprios pacientes (nome, data de nascimento, profissão, etc). Os dados sobre comorbidades associadas, medicamentos utilizados pelo paciente, dosagens de cálcio, da proteína C-reativa, do PTH e da glicose foram obtidos por meio de registros em prontuários dos pacientes, disponíveis em seus respectivos hospitais. Os valores de referência destes exames estão representados no quadro 2.

\begin{tabular}{|cr|}
\hline Cálcio & $8,4-10,5 \mathrm{mg} / \mathrm{dL}^{*}$ \\
\hline Proteína C-reativa & $0,0-0,5 \mathrm{mg} / \mathrm{dL}^{*}$ \\
PTH & $15,0-65,0 \mathrm{pg} / \mathrm{mL}^{*}$ \\
\hline Glicose & $65,0-99,0 \mathrm{mg} / \mathrm{dL}^{*}$ \\
\hline
\end{tabular}

* Valores cedidos pelos laboratórios dos hospitais Quadro 2 - Valores considerados normais para níveis de cálcio, proteína C-reativa, PTH e glicose.

Os pacientes foram pesados e medidos por meio de balanças e antropômetros cedidos pelos hospitais. O diagnóstico do estado nutricional pelo IMC foi realizado utilizando-se os pontos de corte definidos pela Organização Mundial de Saúde (WHO, 1998), conforme descrito no quadro 3.

\begin{tabular}{|l|l|}
\hline CLASSIFICAÇÃO & IMC $\mathbf{~} \mathbf{k g} / \mathbf{m}^{\mathbf{2}} \mathbf{)}$ \\
\hline Abaixo do peso & $<18,50$ \\
\hline Adequado (Eutrofia) & $18,50-24,99$ \\
\hline Pré-obesidade (Sobrepeso) & $25,00-29,99$ \\
\hline Obesidade classe I & $30,00-34,99$ \\
\hline Obesidade classe II & $35,00-39,99$ \\
\hline Obesidade classe III & $>40,0$ \\
\hline
\end{tabular}

Quadro 3 - Classificação do estado nutricional, através do IMC (WHO, 1998) 


\subsection{APLICAÇÃO DE QUESTIONÁRIO (APÊNDICE C)}

A aplicação do questionário consistiu em analisar a detecção da presença de hábitos na rotina diária do paciente, abrangendo questões sobre fatores de risco para o desgaste dentário e autopercepção quanto à saúde bucal.

Dentre os fatores de risco para o desgaste dentário questionou-se quanto à frequência de consumo de refrigerantes e bebidas alcoólicas, escovação, ocorrência de gastrite, vômitos e refluxo, hábitos como bruxismo, apertamento e roer objetos. Foi atribuído um ponto para cada questão com resposta que indicava presença do fator de risco, podendo variar de 0 a 7 .

O questionário de autopercepção da saúde bucal continha seis perguntas (relacionadas à saúde, aparência, mastigação, fala, relacionamento e dor), cujas respostas correspondiam a uma escala de 1 a 5 pontos (de péssima à ótima).

\subsection{EXAME BUCAL}

Foram avaliados fluxo salivar, desgaste dentário e doença periodontal. Nos casos em que havia presença de cárie, este dado era registrado na ficha, embora não tenha sido utilizado um índice para este problema bucal nesta pesquisa. Os pacientes que apresentaram essas condições bucais ruins foram orientados e encaminhados para tratamento odontológico de livre escolha, visto que não havia meios de realizar atendimento odontológico específico pela pesquisadora nos locais da coleta dos dados.

Os exames bucais foram realizados nas salas dos ambulatórios dos 3 hospitais HCRP/FMRP-USP, HB/FAMERP e HC/FMB-UNESP por uma única examinadora previamente calibrada (item 4.3) e devidamente paramentada. Foram utilizados espelhos bucais planos n5, pinça clínic a, gaze e sondas periodontais Carolina do Norte - 15 (Maxter, Marília, São Paulo, Brazil), previamente esterilizados (FIGURA 3).

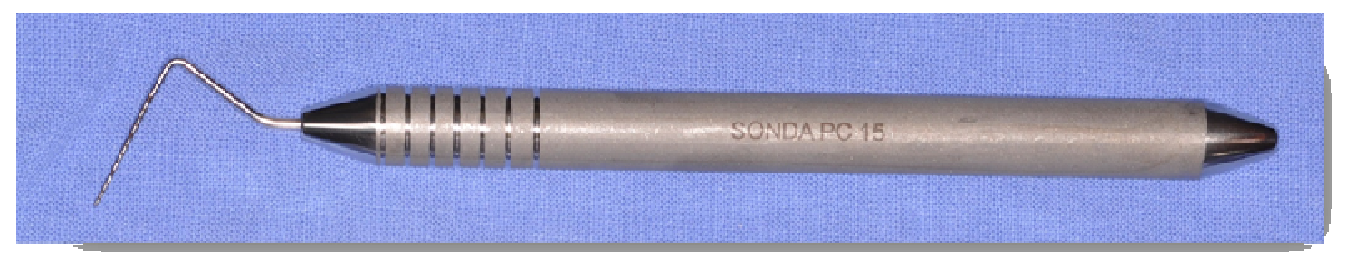

Figura 3 - Sonda periodontal Carolina do Norte-15 
Os pacientes foram examinados deitados em uma maca (FIGURA 4), exceto quando o excesso de peso não possibilitasse sua utilização, sendo avaliado sentado em cadeiras especiais.



Figura 4 - Exame bucal

\subsubsection{Fluxo salivar}

A avaliação do fluxo salivar foi realizada por meio da coleta de saliva estimulada. Durante 5 minutos, os pacientes mascaram um pedaço de látex $(1,0 \mathrm{~cm})$ esterilizado para estimular a produção de saliva e foram orientados a expelir toda saliva produzida em um copo descartável pequeno. Posteriormente, utilizando-se uma seringa descartável graduada $(5 \mathrm{~mL})$, o volume de saliva foi medido em $\mathrm{mL}$ e divido por 5 (tempo de coleta) para a obtenção do fluxo em $\mathrm{mL} / \mathrm{min}$, sendo considerados normais os valores entre 1,0 e $3,0 \mathrm{~mL} / \mathrm{min}$ (DIAZ-LOBATO; NAVARRO; PEREZ-RODRIGUEZ, 2008). (QUADRO 4).

\begin{tabular}{|c|c|}
\hline FLUXO SALIVAR & Volume/ Minuto \\
\hline Normal & $1,01---13,0 \mathrm{~mL}$ \\
Baixo & 0,7 --- $1,0 \mathrm{~mL}$ \\
Hipossalivação & Abaixo de $0,7 \mathrm{~mL}$ \\
\hline
\end{tabular}

Quadro 4 - Classificação do fluxo salivar. 


\subsubsection{Desgaste Dentário}

Para o desgaste dentário foi adotado o índice proposto por Sales-Peres et al. (2008), o qual permite avaliar a prevalência e a severidade do desgaste (QUADRO 5). Este índice foi registrado em ficha específica (APÊNDICE D), para facilitar a tabulação dos dados (SALES-PERES et al., 2008). O exame para identificar desgaste dentário foi precedido por secagem das superfícies dentárias com gaze facilitando o diagnóstico visual.

O valor foi obtido pela razão entre número de faces com desgaste e o número total de faces avaliadas, sendo multiplicado por 100. Dessa forma, obteve-se uma porcentagem de faces com desgaste, podendo ser calculado de acordo com o substrato envolvido, esmalte ou dentina.

\begin{tabular}{|c|c|c|}
\hline Escores & Critério & Descrição \\
\hline 0 & $\begin{array}{l}\text { Norma I- sem evidência de } \\
\text { desgaste }\end{array}$ & $\begin{array}{l}\text { Nenhuma perda nas características do } \\
\text { esmalte }\end{array}$ \\
\hline 1 & $\begin{array}{l}\text { Incipiente - desgaste em } \\
\text { esmalte }\end{array}$ & $\begin{array}{l}\text { Perda nas características da superfície do } \\
\text { esmalte, sem envolvimento da dentina }\end{array}$ \\
\hline 2 & $\begin{array}{l}\text { Moderado - desgaste } \\
\text { envolvendo dentina }\end{array}$ & Perda de esmalte com exposição da dentina \\
\hline 3 & $\begin{array}{l}\text { Severo - desgaste se } \\
\text { estendendo até a polpa }\end{array}$ & $\begin{array}{l}\text { Extensa perda de esmalte e dentina com } \\
\text { exposição de dentina secundária ou da polpa }\end{array}$ \\
\hline 4 & $\begin{array}{l}\text { Restauração - restaurado por } \\
\text { causa de desgaste }\end{array}$ & $\begin{array}{l}\text { O dente recebeu tratamento restaurador } \\
\text { devido ao desgaste }\end{array}$ \\
\hline 9 & Sem registro & $\begin{array}{l}\text { Cáries extensas, restauração grande, dente } \\
\text { com fratura ou dente ausente }\end{array}$ \\
\hline
\end{tabular}

Quadro 5 - Índice de desgaste dentário (IDD)- códigos e critérios utilizados.

\subsubsection{Doença periodontal}

\subsubsection{Profundidade de sondagem}

A profundidade de sondagem correspondeu à distância da margem gengival ao ponto mais apical do fundo do sulco/bolsa. Esta tomada foi realizada com sonda periodontal manual milimetrada tipo Carolina do Norte - 15 (Maxter, Marília, SP, Brasil) com leve pressão o mais paralelo possível ao longo do eixo do dente 
(FIGURA 5), em 6 sítios de cada dente (distovestibular, centro da face vestibular, mesiovestibular, distolingual, centro da face lingual e mesiolingual).

Os dados foram registrados em ficha clínica própria (APÊNDICE E). Foi registrada também a presença de cálculo por dente, sendo os achados expressos em porcentagem, relativo ao número de dentes presentes.

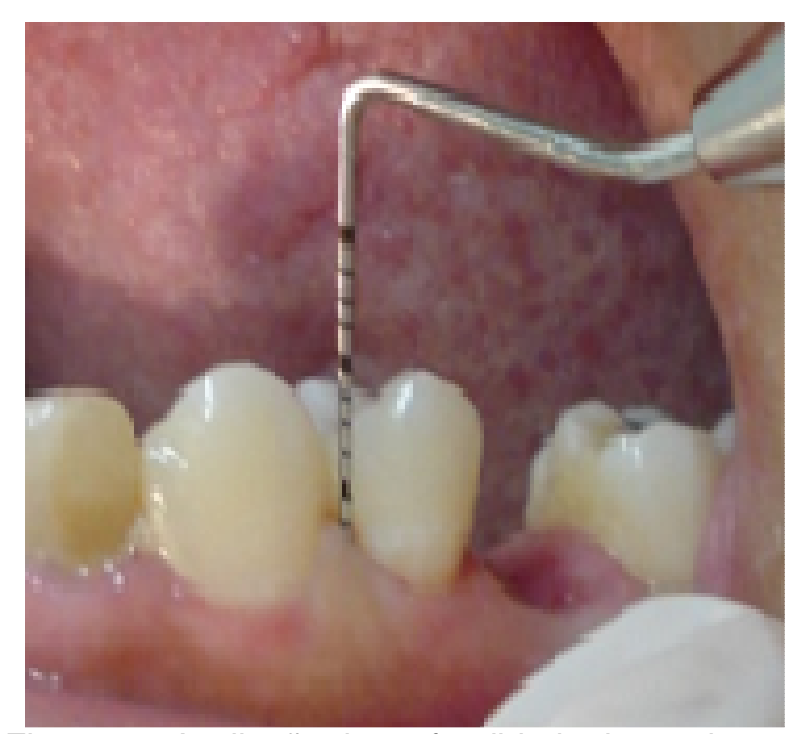

Figura 5 - Avaliação da profundidade de sondagem 


\subsubsection{2 Índice de sangramento gengival - ISG}

O ISG refere-se à presença ou ausência de sangramento após a sondagem do sulco gengival com sonda periodontal, mesmo sem características clínicas visíveis de alterações marginais. Foi considerado ISG positivo quando ocorreu sangramento em até 10 segundos após a sondagem (AINAMO et al., 1982). O número de achados positivos foi expresso em porcentagem, relativo ao número de dentes presentes.

\subsubsection{Nível de Inserção clínica/ recessão gengival}

O nível de inserção clínica foi avaliado com a mesma sonda periodontal e traduzido como a distância em milímetros da junção cemento-esmalte até o fundo do sulco gengival ou da bolsa nos 6 sítios correspondentes à sondagem.

A recessão gengival correspondeu à distância da margem gengival até a junção cemento-esmalte.

\subsubsection{4 Índice Periodontal Comunitário}

Para fins epidemiológicos, os dados da avaliação periodontal também foram categorizados de acordo com a classificação do índice periodontal comunitário (IPC), preconizada pela OMS (WHO, 1997), codificando a pior situação de cada paciente (QUADRO 6). Foram realizadas duas categorizações, uma considerando todos os dentes avaliados e outra considerando apenas os dentes índices como descrito para o IPC. 


\begin{tabular}{|cl|}
\hline CÓDIGO & CRITÉRIO \\
\hline $\mathbf{0}$ & Hígido \\
$\mathbf{1}$ & Sangramento \\
$\mathbf{2}$ & Cálculo - qualquer quantidade existente \\
$\mathbf{3}$ & Bolsa de 4 ou $5 \mathrm{~mm}$ \\
$\mathbf{4}$ & Bolsa de $6 \mathrm{~mm}$ ou mais \\
$\mathbf{X}$ & Nulo - dente ausente \\
$\mathbf{9}$ & Não informado - não foi possível avaliar \\
\hline Quadro 6 - Códigos e critérios do IPC \\
\hline
\end{tabular}

Assim como para sangramento gengival e cálculo dentário, a quantidade de sítios com bolsa de $4-5 \mathrm{~mm}$ e de bolsa $\geq 6 \mathrm{~mm}$ foi expressa em porcentagem, em relação ao número total de sítios avaliados.

\subsubsection{Coleta de amostra do fluido gengival}

Amostras de fluido gengival foram coletadas com tiras de papel absorvente estéril (FIGURA 6) para a detecção das bactérias: Porphyromonas gingivalis, Tannerella forsythia, Treponema denticola e Prevotella intermedia. Para coletar o fluido do sulco gengival foi selecionado um dente por sextante com a maior profundidade de sondagem encontrada, sendo utilizados os mesmos nas avaliações pós-operatórias, mesmo se a profundidade de sondagem não fosse mais a pior. Quando a profundidade de sondagem era semelhante na boca toda, os dentes de referência foram os "dentes índices" adotados pelo IPC. Na ausência de um dente índice coletava-se do dente adjacente. A região da coleta foi secada com gaze. A tira de papel foi posicionada dentro do sulco gengival durante 45 segundos (RAl et al., 2008) e posteriormente guardada em pequenos tubos estéreis identificados até a sua manipulação. Para transportar este material coletado do hospital até o laboratório, os tubos foram colocados em um isopor contendo gelo. No laboratório foram organizados em um suporte de plástico e armazenados em um freezer à temperatura de $-20^{\circ} \mathrm{C}$ (vinte graus Celsius abaixo de zero) até o momento de sua análise. 


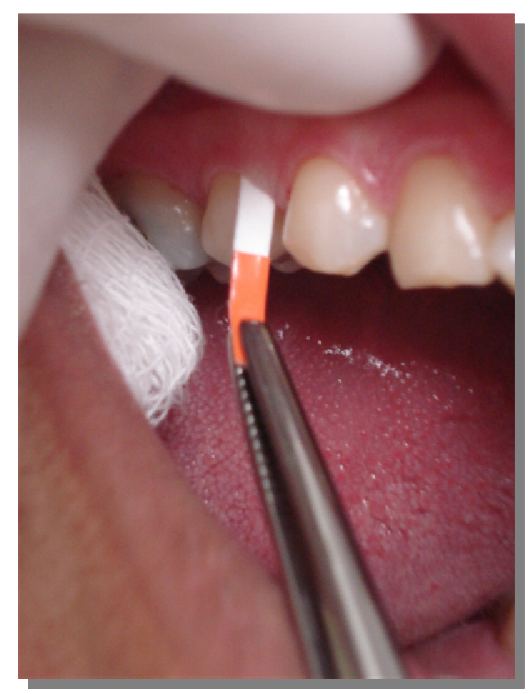

Figura 6 - Coleta do fluido gengival

\subsection{DETECÇÃO E QUANTIFICAÇÃO DE BACTÉRIAS PERIODONTOPATOGÊNICAS}

Para a detecção de Porphyromonas gingivalis, Tannerella forsythia, Treponema denticola e Prevotella intermedia a partir das amostras de fluido gengival coletadas (item 4.7.4) foram utilizadas reações em cadeia da polimerase em tempo real ou quantitativa (quantitative or real-time polymerase chain reaction - q-PCR). Essas bactérias Gram-negativas foram incluídas no estudo, uma vez que se apresentam com maior frequência na etiologia da doença periodontal, especialmente alojadas em bolsas periodontais profundas e por terem sido associadas à severidade da doença (FERREIRA et al., 2008; NOIRI et al., 2004; SOCRANSKY et al., 1991; TROMBONE et al., 2009). Além disso, foram associadas com perda óssea alveolar e IMC (BRENNAN et al., 2007). 


\subsubsection{Extração de DNA}

A extração de DNA bacteriano foi realizada no Laboratório de Imunogenética do Hospital de Reabilitação de Anomalias Craniofaciais (HRAC-USP), seguindo o protocolo descrito por Sakai (SAKAI et al., 2007), com utilização de InstaGene Matrix (Bio-Rad Laboratories. Inc., Hercules, CA, USA). Em seguida, as amostras foram analisadas referente à quantidade e à pureza do DNA por densidade óptica em espectrofotômetro (NanoDrop ${ }^{T M} 1000$ Thermo Scientific, USA). A leitura foi repetida nas amostras que apresentaram resultados duvidosos, sendo excluídas quando o resultado não foi satisfatório.

Foram selecionadas ainda 9 amostras com diferentes concentrações e com qualidade na faixa aceitável (razão 260/280) para serem testadas (piloto da fase laboratorial) com par de primers universal para bactérias a fim de verificar quais os valores limites para ocorrer a reação adequadamente. Foi observado que com uma concentração mínima de DNA de $3 \mathrm{ng} / \mu \mathrm{l}$ a reação ocorre adequadamente. Portanto, como a mínima concentração encontrada foi de $5,8 \mathrm{ng} / \mu \mathrm{l}$, todas as amostras foram diluídas a valores próximos a $6 \mathrm{ng} / \mu \mathrm{l}$ com adição de água Milli-Q, a fim de padronizar as concentrações previamente à amplificação do DNA para possibilitar a comparação entre os grupos.

\subsubsection{Etapas do processo de q-PCR}

Os DNAs extraídos foram amplificados no mesmo laboratório, marcados com o reagente SYBR® Green Master Mix (Applied Biosystems, Foster City, CA, USA) para $q-P C R$. O corante SYBR® Green Master Mix utilizado é um marcador fluorescente que possui ligação altamente específica ao DNA dupla-fita e detecta o produto da q-PCR conforme ele se acumula durante os ciclos da reação (APPLIEDBIOSYSTEMS, 2008; LIFE-TECHNOLOGIES, 2011).

Foram utilizados primers específicos para cada bactéria que se desejava investigar e um primer universal (16S) para bactérias a fim de verificar a presença de DNA bacteriano e permitir a quantificação relativa. As sequências destes primers e as temperaturas de anelamento foram obtidas da literatura científica (ESTRELA et al., 2010; FERREIRA et al., 2008; PRICE et al., 2007; RAMSEIER et al., 2009) e estão descritas na Tabela 1. 
Tabela 1 - Sequência dos primers e temperatura de anelamento $\left(T_{a}\right)$.

\begin{tabular}{|c|c|c|c|}
\hline Bactéria & Seqüência & $T_{a \cdot}$ & Referência \\
\hline$P$. intermedia & $\begin{array}{l}\text { F- GTGGCGCGTATTTTATTGTATGTG } \\
\text { R- ATCCGCCATACGCCCTTAG }\end{array}$ & $60^{\circ} \mathrm{C}$ & Price et al 2007 \\
\hline$P$. gingivalis & $\begin{array}{l}\text { F- AGGCAGCTTGCCATACTGCG } \\
\text { R- ACTGTTAGCAACTACCGATGT }\end{array}$ & $56^{\circ} \mathrm{C}$ & Estrela et al 2010 \\
\hline T. denticola & $\begin{array}{l}\text { F- AGAGCAAGCTCTCCCTTACCGT } \\
\text { R- TAAGGGCGGCTTGAAATAATGA }\end{array}$ & $59^{\circ} \mathrm{C}$ & Ferreira et al 2008 \\
\hline T. forsythia & $\begin{array}{l}\text { F-GGGTGAGTAACGCGTATGTAACCT } \\
\text { R- ACCCATCCGCAACCAATAAA }\end{array}$ & $59^{\circ} \mathrm{C}$ & Ferreira et al 2008 \\
\hline Universal 16S & $\begin{array}{l}\text { F- CCATGAAGTCGGAATCGCTAG } \\
\text { R- GCTTGACGGGCGGTGT }\end{array}$ & $60^{\circ} \mathrm{C}$ & Ramseier et al 2009 \\
\hline
\end{tabular}

F-forward; R- reverse

Como mostra a figura 7, a etapa de q-PCR constituiu dos seguintes passos: os primers foram diluídos a uma concentração de $50 \mu \mathrm{M}$. Uma alíquota de $200 \mu \mathrm{L}$ a $25 \mu \mathrm{M}$ foi obtida a partir de $100 \mu \mathrm{L}$ do primer $\mathrm{F}$ (forward) e $100 \mu \mathrm{L}$ do $\mathrm{R}$ (reverse). Para então obter $200 \mu \mathrm{L}$ de uma alíquota de concentração de $10 \mu \mathrm{M}$, que é a utilizada para a reação, utilizaram-se $80 \mu \mathrm{L}$ da alíquota $25 \mu \mathrm{M}$ diluída em $120 \mu \mathrm{L}$ de água Milli-Q (FIGURA 7A). Para a montagem da placa de q-PCR, cada poço foi preenchido em duplicata com $5 \mu \mathrm{L}$ de amostra de DNA, 7,5 $\mu \mathrm{L}$ de SYBR® Green Mater Mix que corresponde à metade do volume total (recomendações do fabricante), 0,6 $\mu \mathrm{L}$ de primer a $10 \mu \mathrm{M}$ e completados com 1,9 $\mu \mathrm{L}$ de água Milli-Q (FIGURA 7B). A placa foi centrifugada apenas para dar um giro, ou seja, assentar o líquido no fundo dos poços (FIGURA 7C), de modo que não constasse qualquer resquício nas paredes. Em seguida a placa foi selada (FIGURA 7D) e levada ao termociclador 7500 Real Time PCR System (Applied Biosystems, CA, USA) (FIGURA 8), previamente calibrado com o corante de referência passiva ROX (Applied Biosystems, Foster City, CA, USA).

O processo de termociclagem consistiu de 45 ciclos, cada um composto por desnaturação a $95^{\circ} \mathrm{C}$ por 30 segundos, anelamento com temperatura preconizada para cada bactéria (Tabela 1) por 1 minuto e extensão a $72^{0} \mathrm{C}$ por 1 minuto.

As leituras foram feitas pelo software 7500 Real Time PCR System (Applied Biosystems, CA, USA). 

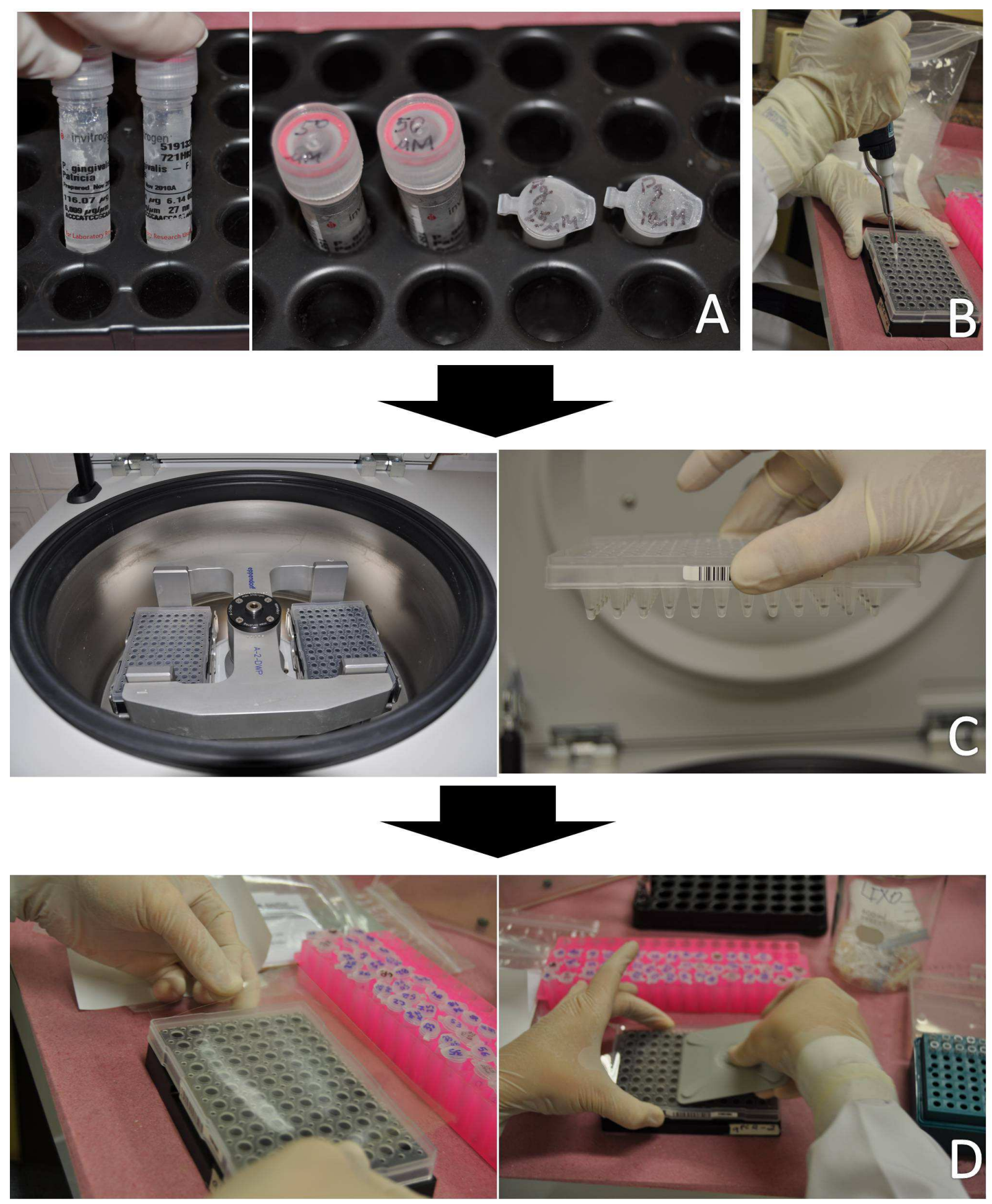

FIGURA 7 - Montagem da placa de q-PCR 


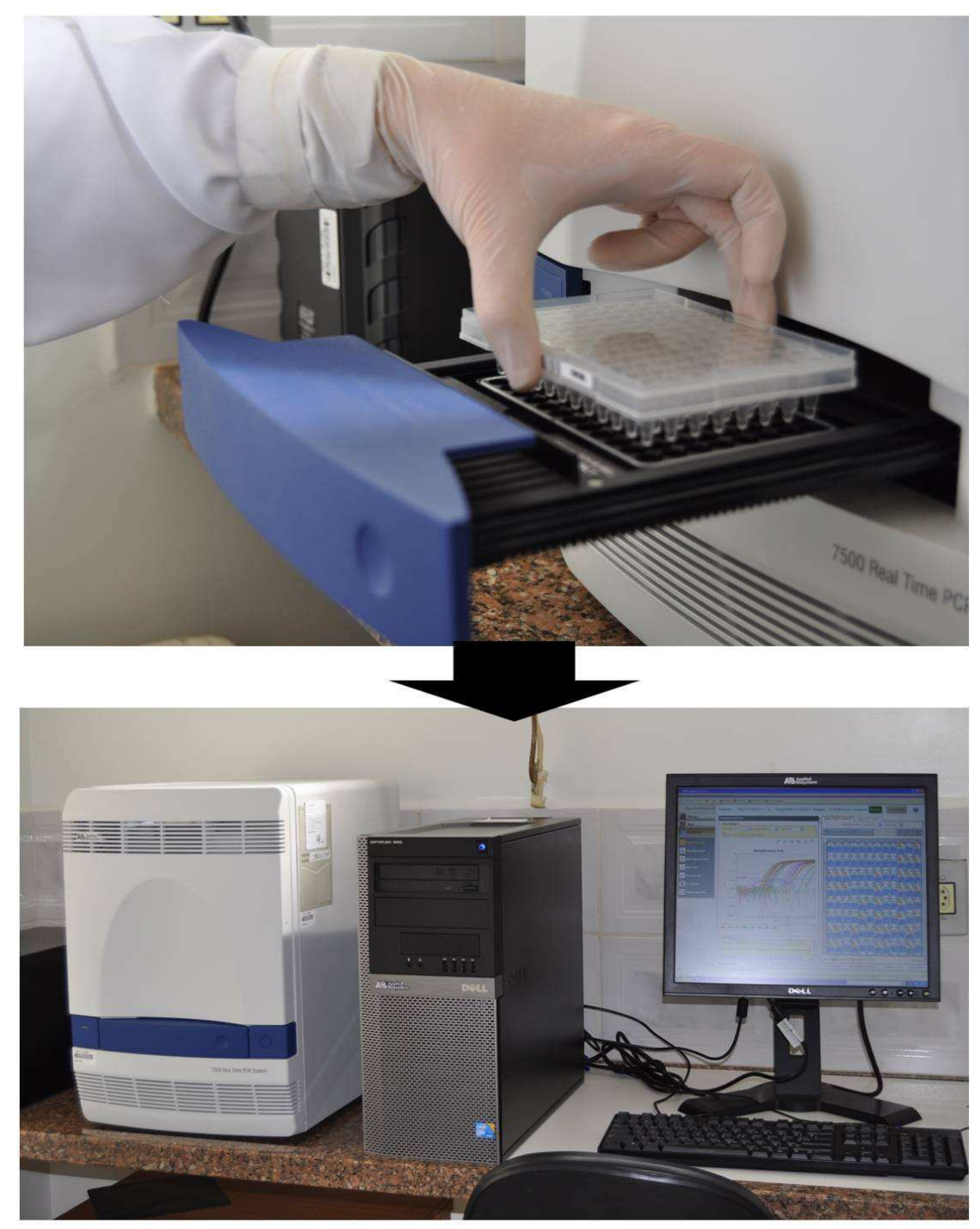

FIGURA 8 - Colocação da placa no termociclador

A quantificação absoluta é obtida com base no valor $\mathrm{Ct}$ (cicle threshold), quando o número de ciclos de amplificação atinge um limiar, comparado aos valores Ct de uma curva padrão construída com amostras de concentrações conhecidas (APPLIED-BIOSYSTEMS, 2008; LIFE-TECHNOLOGIES, 2011)

Para a bactéria P.gingivalis, foi possível realizar a quantificação absoluta a partir da comparação com uma amostra padrão de concentração conhecida desta bactéria e suas diluições seriadas de $10^{8}$ a $10^{0}$, disponibilizadas pelo Laboratório da Disciplina de Fisiologia e Farmacologia da FOB/USP. Por meio dos valores do $\mathrm{Ct}$ das curvas padrão equivalentes às concentrações já conhecidas $\left(10^{0}, 10^{1}, \ldots, 10^{8}\right)$ foi obtido no programa Excel um gráfico de dispersão onde se inseriu uma linha de 
tendência exponencial que forneceu a fórmula para determinar 0 valor correspondente ao $\mathrm{Ct}$ das amostras a serem quantificadas (FIGURA 9). O número total de bactérias foi dividido por 5 que era a quantidade de amostra em microlitro $(\mu \mathrm{L})$, a fim de obter o número de P.gingivalis por $\mu \mathrm{L}$.

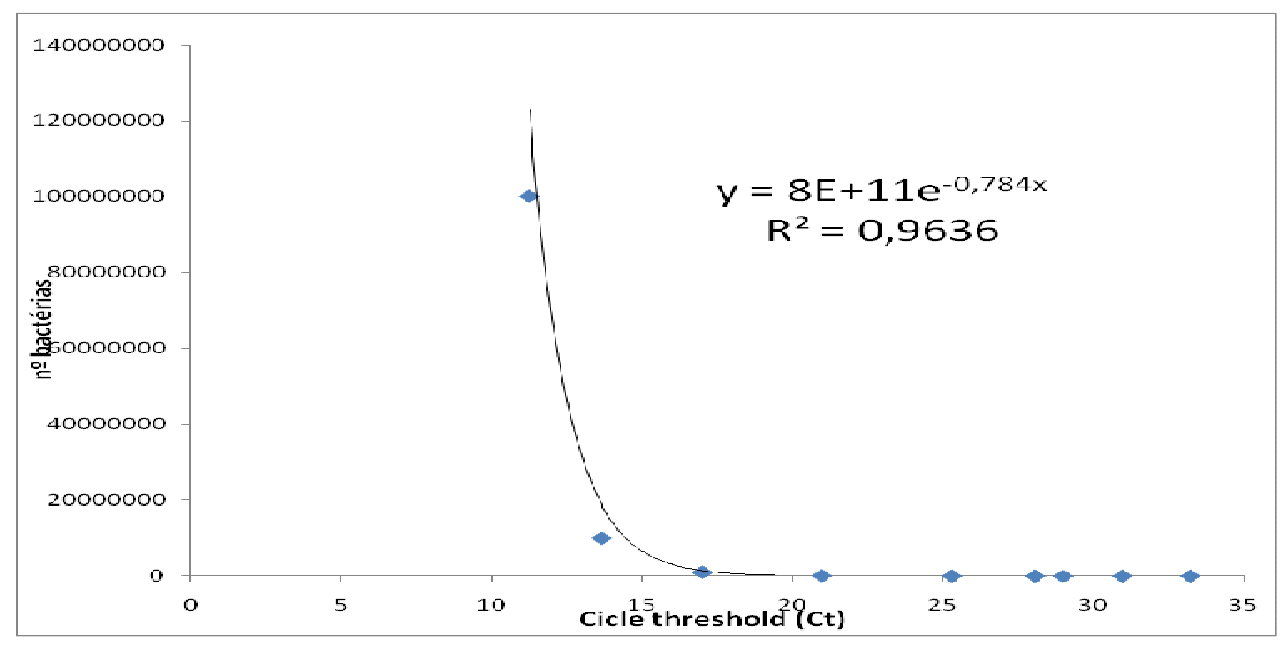

$\mathrm{Y}=$ quantidade de bactérias ( $P$.gingivalis);

$e=$ constante de Euler $(2,718281)$;

$\mathrm{x}=$ valor do $\mathrm{Ct}$ da amostra que se deseja quantificar.

Figura 9 - Gráfico de dispersão e linha de tendência exponencial obtidos dos valores dos Cts das curvas padrão para a bactéria P.gingivalis.

Para as demais bactérias (Tannerella forsythia, Treponema denticola e Prevotella intermedia), foi realizada a quantificação relativa (RQ). Quanto maior a $R Q$, maior o número de bactérias. $A R Q$ foi calculada por meio da fórmula (SCHMITTGEN; LIVAK, 2008):

$\mathrm{RQ}=2^{-\Delta \mathrm{Ct}}$, onde $\Delta \mathrm{Ct}=\mathrm{Ct}$ do alvo $-\mathrm{Ct}$ do universal 


\subsection{ANÁLISE DOS DADOS}

Os dados coletados e anotados foram organizados em arquivos do programa Excel 2007, para posterior análise descritiva (média, desvio-padrão, frequências absolutas e relativas) e analítica utilizando-se o programa estatístico Statistica 7.0 for Windows, adotando-se nível de significância de 5\%.

Após verificada a normalidade das variáveis, o teste $t$ de Student foi utilizado para avaliar as diferenças entre os grupos obeso e não obeso. Para avaliar as diferenças entre os períodos pré, pós-operatório de 6 meses e pós-operatório de 12 meses foi realizada ANOVA para medidas repetidas, seguida pelo teste de Tukey. $\mathrm{O}$ teste de Correlação de Pearson também foi utilizado para verificar a relação entre as variáveis quantitativas em cada período. 



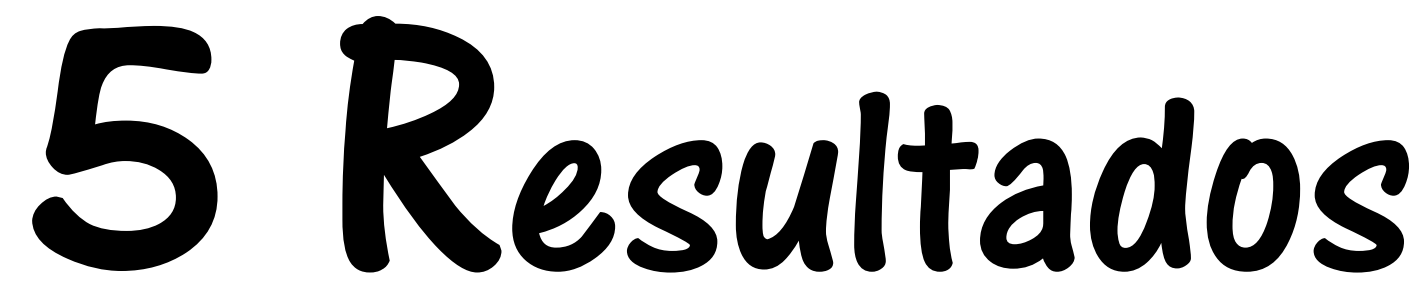





\section{RESULTADOS}

\subsection{AVALIAÇÃO PRÉ CIRURGIA BARIÁTRICA}

\subsubsection{Pacientes obesos mórbidos (baseline)}

Foram avaliados 91 pacientes obesos mórbidos (IMC médio de 50,41 $\pm 9,97$ $\mathrm{kg} / \mathrm{m}^{2} ; 35,45-97,45 \mathrm{~kg} / \mathrm{m}^{2}$ ), 46\% com IMC>50 (super obesidade), 74 mulheres $(82,2 \%)$ e 16 homens $(17,8 \%)$, com idade média de $38,90 \pm 10,13$ anos.

Os pacientes apresentaram em média níveis séricos normais para cálcio $(9,25$ $\pm 0,53 \mathrm{mg} / \mathrm{dL})$ e PTH $(57,07 \pm 26,99 \mathrm{pg} / \mathrm{mL})$, elevados para proteína C-reativa $(1,97$ $\pm 2,98 \mathrm{mg} / \mathrm{dL}$ ) e para glicose $(106,41 \pm 36,49 \mathrm{mg} / \mathrm{dL})$. O percentual de pacientes que apresentaram níveis elevados de PTH foi $30 \%$, de proteína C-reativa foi $69 \%$ e de glicose foi $36 \%$.

Houve correlação positiva estatisticamente significativa $(r=0,351 ; p=0,004)$ entre IMC e níveis séricos de proteína C-reativa.

A média do fluxo salivar dos pacientes obesos indicados à cirurgia bariátrica foi $0,83 \pm 0,57 \mathrm{~mL} / \mathrm{min}$, considerado baixo (entre 0,7 a 1,0 ), sendo que $46,7 \%$ apresentaram hipossalivação (menor que $0,7 \mathrm{~mL} / \mathrm{min}$ ) e apenas $28,9 \%$ fluxo salivar normal. Não foi observada relação entre fluxo salivar e glicemia.

Quanto ao desgaste dentário, 6.619 faces dentárias foram avaliadas (em média 72,74 faces por paciente). Destas, 2016 (30,4\%) apresentavam desgaste dentário, sendo $20 \%$ em esmalte e $11 \%$ em dentina. Das faces com desgaste, $79 \%$ correspondiam à face incisal/oclusal, $13 \%$ à lingual e $8 \%$ à vestibular. Os dentes incisivos foram os mais acometidos pelo desgaste (tabela 2). 
Tabela 2 - Distribuição da severidade e prevalência de desgaste dentário por grupo de dentes dos pacientes obesos indicados à cirurgia bariátrica.

\begin{tabular}{lrr|rr|rr|rr|rr}
\hline & \multicolumn{2}{c|}{ Incisivos } & \multicolumn{2}{|c|}{ Caninos } & \multicolumn{2}{|c|}{ Pré-molares } & \multicolumn{2}{|c}{ Molares } & \multicolumn{2}{c}{ TOTAL } \\
Severidade & $\mathbf{n}$ & $\%$ & $\mathbf{n}$ & $\%$ & $\mathbf{n}$ & $\%$ & $\mathbf{n}$ & $\%$ & $\mathbf{n}$ & $\%$ \\
\hline 1 & 445 & 6,7 & 240 & 3,6 & 363 & 5,5 & 312 & 4,7 & 1360 & 20,5 \\
2 & 341 & 5,2 & 164 & 2,5 & 87 & 1,3 & 23 & 0,3 & 615 & 9,3 \\
3 & 4 & 0,1 & 2 & 0,0 & 1 & 0,0 & - & - & 7 & 0,1 \\
4 & 16 & 0,2 & 4 & 0,1 & 7 & 0,1 & 7 & 0,1 & 34 & 0,5 \\
\hline Prevalência & $\mathbf{n}$ & $\%$ & $\mathbf{n}$ & $\%$ & $\mathbf{n}$ & $\%$ & $\mathbf{n}$ & $\%$ & $\mathbf{n}$ & $\%$ \\
\hline Sim & 806 & 12,2 & 410 & 6,2 & 458 & 6,9 & 342 & 5,1 & 2016 & 30,4 \\
Não & 1160 & 17,5 & 576 & 8,7 & 1310 & 19,8 & 1557 & 23,5 & 4603 & 69,5 \\
\hline
\end{tabular}

n=número de faces avaliadas, 1=incipiente, 2=moderado, 3=severo, 4= Restaurado devido ao desgaste

Foi observado que $66 \%$ dos pacientes obesos apresentavam pelo menos um fator para a ocorrência de desgaste dentário, destes $73 \%$ refere-se ao bruxismo, apertamento ou hábito de roer objetos.

As médias de profundidade de sondagem e nível de inserção foram $1,90 \pm 0,50 \mathrm{~mm}$ e $2,00 \pm 0,60 \mathrm{~mm}$, respectivamente, sendo maiores entre os obesos diabéticos $(p=0,011$ e $p<0,000)$. Os pacientes diabéticos, quando comparados aos não diabéticos, apresentaram maior percentual de sítios com bolsa periodontal maior ou igual a $4 \mathrm{~mm}(\mathrm{p}<0,000)$.

Em média os pacientes obesos apresentaram $22 \%$ dos dentes com sangramento à sondagem e $24 \%$ com cálculo. Quanto à classificação de acordo com o IPC apenas 10\% foram classificados como hígido, enquanto que $12,3 \%$ com a pior condição (bolsa $\geq 6 \mathrm{~mm}$ ). Predominou como pior condição periodontal a presença de cálculo dentário (40\%), seguido por bolsa 4-5mm (33\%). Foi observado que 17,5\% dos pacientes tinham menos de 20 dentes na boca.

As médias da profundidade de sondagem, do índice de sangramento gengival (ISG), do índice de cálculo (IC) e da porcentagem de sítios com bolsa acima de 4 $\mathrm{mm}$ não apresentaram diferenças estatisticamente significativas entre os pacientes com proteína C-reativa alta ou normal. No entanto quando avaliada as diferenças na média da proteína C-reativa nos diferentes graus do IPC foi observada maior média nos indivíduos com sangramento gengival, apresentando 7,50 mg/dL ( $p=0,027)$.

Em relação à autopercepção da saúde bucal, 56,9\% a consideraram de boa a ótima, sendo que quanto maior a profundidade de sondagem e nível de inserção periodontal menor foi o grau de satisfação quanto à saúde bucal $(p=0,005$ e 
$p=0,000$, respectivamente). Não houve diferença estatisticamente significativa entre autopercepção em saúde bucal e o IMC ( $p>0,050)$.

\subsubsection{Comparação com um grupo controle (IMC normal)}

O grupo controle foi composto por 14 homens e 37 mulheres, com média de 41,68 anos e IMC de 23,45 $\pm 2,83 \mathrm{~kg} / \mathrm{m}^{2}$. O ISG, IC e \% de sítios com bolsa $4-5 \mathrm{~mm}$ foram maiores nos obesos, sendo esta diferença estatisticamente significativa $(p<0,050)$, mesmo excluindo os diabéticos da análise estatística. A maior profundidade de bolsa periodontal encontrada foi de $10 \mathrm{~mm}$ nos obesos e $4 \mathrm{~mm}$ no grupo controle.

O grupo de não obesos apresentou melhor autopercepção da saúde bucal que os obesos $(p=0,008)$. A tabela 3 mostra a comparação entre os grupos quanto às variáveis analisadas.

Tabela 3- Comparação das variáveis entre os grupos controle e obeso

\begin{tabular}{|c|c|c|c|c|}
\hline \multirow{2}{*}{ Variáveis } & \multicolumn{2}{|c|}{ Controle } & Obeso & \multirow[b]{2}{*}{$p$} \\
\hline & Média & $\pm d p$ & Média $\pm d p$ & \\
\hline Idade (anos) & 41,68 & $\pm 10,84$ & $38,41 \pm 10,98$ & 0,165 \\
\hline $\mathrm{IMC}\left(\mathrm{kg} / \mathrm{m}^{2}\right)$ & 23,45 & $\pm 2,83$ & $46,61 \pm 7,94$ & $0,000^{*}$ \\
\hline Fluxo salivar (mL/min) & 0,93 & $\pm 0,54$ & $0,87 \pm 0,54$ & 0,579 \\
\hline Índice de desgaste em esmalte (\% de faces) & 16,69 & $\pm 10,90$ & $19,56 \pm 8,42$ & 0,175 \\
\hline Índice de desgaste em dentina (\% de faces) & 11,94 & $\pm 7,57$ & $11,13 \pm 10,41$ & 0,676 \\
\hline Dentes presentes & 26,97 & $\pm 3,86$ & $25,90 \pm 6,13$ & 0,321 \\
\hline $\mathrm{PS}(\mathrm{mm})$ & 1,83 & $\pm 0,23$ & $\pm 0,45$ & 0,734 \\
\hline $\mathrm{NIC}(\mathrm{mm})$ & 1,89 & $\pm 0,26$ & $1,93 \pm 0,57$ & 0,644 \\
\hline ISG (\% de dente) & 3,13 & $\pm 5,76$ & $16,4 \pm 14,48$ & $0,000^{*}$ \\
\hline IC (\% de dente) & 13,48 & $\pm 13,43$ & $22,25 \pm 18,65$ & $0,012^{*}$ \\
\hline Bolsa 4-5 mm (\% de sítio) & 0,67 & $\pm 1,17$ & $2,19 \pm 3,48$ & $0,006^{*}$ \\
\hline Bolsa $\geq 6 m m$ (\% de sítio) & 0,08 & $\pm 0,43$ & $\pm 2,24$ & 0,207 \\
\hline Autopercepção da saúde bucal (0-5) & 3,89 & $\pm 0,44$ & $3,52 \pm 0,80$ & $0,008^{*}$ \\
\hline
\end{tabular}

*Estatisticamente significativo; $\mathrm{dp}=$ desvio-padrão; $\mathrm{PS}$ = profundidade de sondagem; $\mathrm{NIC}=$ nível de inserção clínica; ISG = índice de sangramento gengival; IC = índice de cálculo

\subsection{AVALIAÇÃO APÓS CIRURGIA BARIÁTRICA}

Até o final de novembro de 2011 dos 91 pacientes avaliados, 71 foram submetidos à cirurgia bariátrica. Destes, perderam-se 10 por diversos motivos como óbito, recusa a continuar participando, não localizados, entre outros. Portanto, 61 
pacientes foram examinados após 6 meses de cirurgia. Houve uma perda de mais 11 pacientes dos quais 2 não completaram 12 meses de cirurgia até a data limite da coleta (novembro de 2011), 3 não compareceram a consulta (que foram agendadas por 3 vezes), 2 não foram localizados e 4 estavam gestantes, sendo 50 pacientes examinados após 12 meses de cirurgia. A figura 10 ilustra a composição da amostra e os motivos das perdas.

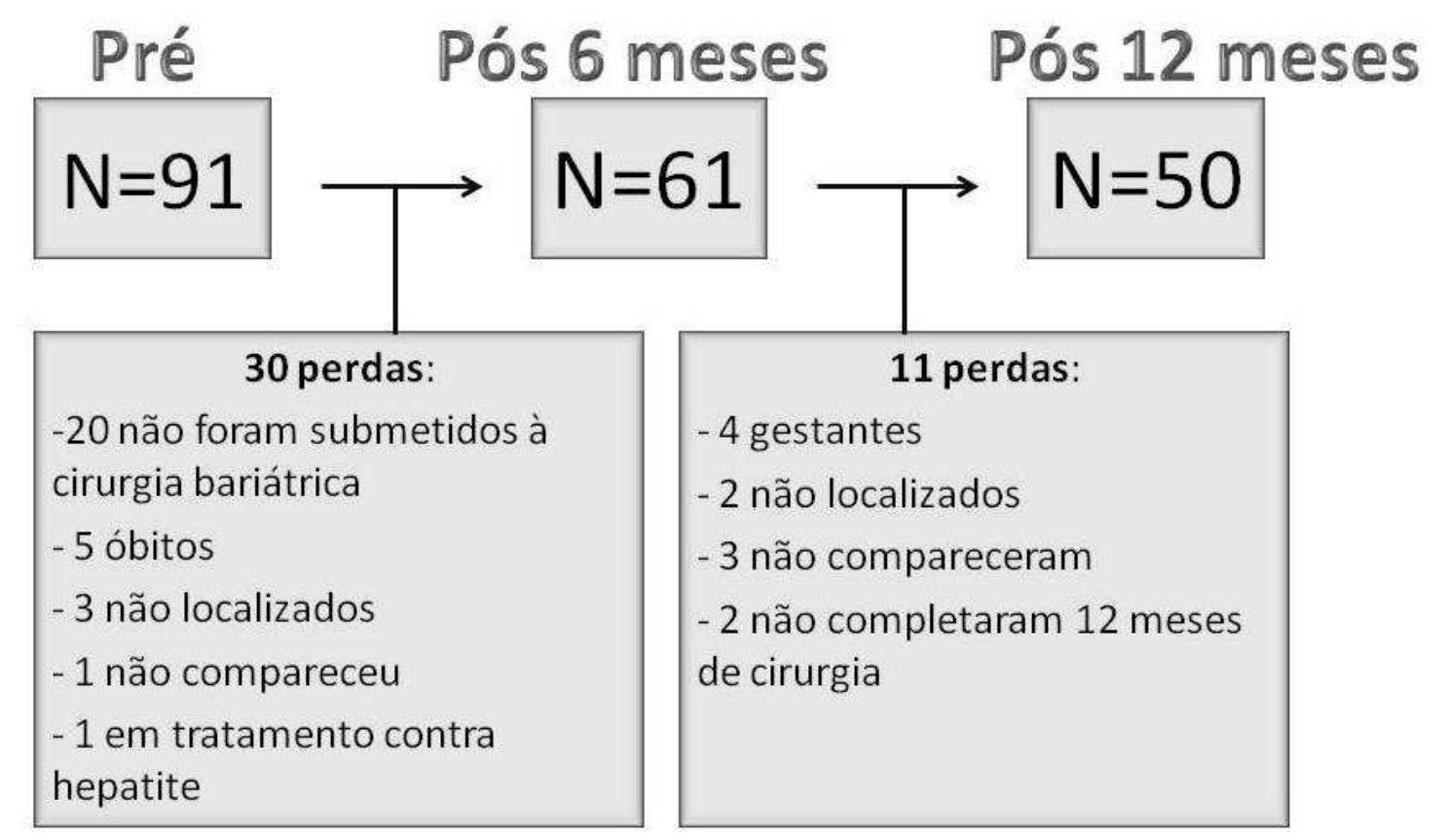

Figura 10 - Tamanho da amostra nos 3 períodos avaliados e motivos das perdas.

Dos 5 pacientes que foram a óbito, 4 foram tardias (de 1 a 5 meses após cirurgia), destas, 2 mulheres apresentavam $\mathrm{IMC}>60 \mathrm{~kg} / \mathrm{m}^{2}$ e nenhum deles era idoso.

Para a avaliação de 6 meses, 52 eram mulheres e 9 homens. Nos 12 meses, 42 mulheres e 8 homens foram avaliados.

A tabela 4 mostra as médias e os desvios-padrão das principais variáveis nos 3 períodos avaliados, indicando as variáveis que ocorreram alterações estatisticamente significativas por letras diferentes $(p<0,050)$. 
Tabela 4 - Alterações observadas nas variáveis ao longo do tempo $(n=50)$

\begin{tabular}{|c|c|c|c|}
\hline \multirow{2}{*}{ Variáveis } & Antes & Após 6 meses & $\begin{array}{c}\text { Após } 12 \\
\text { meses }\end{array}$ \\
\hline & Média $\pm d p$ & Média $\pm d p$ & Média $\pm d p$ \\
\hline Cálcio (mg/dL) & $9,37 \pm 0,56$ & $9,46 \pm 0,52$ & $9,49 \pm 0,51$ \\
\hline Proteína C-reativa (mg/dL) & $1,73 \pm 2,63^{A}$ & $0,42 \pm 0,41^{\mathrm{B}}$ & $0,19 \pm 0,24^{\mathrm{E}}$ \\
\hline PTH (pg/dL) & $59,88 \pm 26,99$ & $60,53 \pm 34,01$ & $60,54 \pm 28,35$ \\
\hline Glicemia (mg/dL) & $103,57 \pm 36,49^{A}$ & $81,86 \pm 14,77^{\mathrm{B}}$ & $83,32 \pm 15,06^{\mathrm{E}}$ \\
\hline IMC $\left(\mathrm{kg} / \mathrm{m}^{2}\right)$ & $49,69 \pm 8,91^{\mathrm{A}}$ & $36,16 \pm 7,05^{\mathrm{B}}$ & $32,26 \pm 5,78$ \\
\hline Fluxo salivar (mL/min) & $0,87 \pm 0,55$ & $0,96 \pm 0,60$ & $0,86 \pm 0,56$ \\
\hline Índice de desgaste em esmalte (\% de faces) & $19,84 \pm 9,53^{\mathrm{A}}$ & $16,19 \pm 8,05^{\mathrm{B}}$ & $16,36 \pm 7,08^{\mathrm{E}}$ \\
\hline Índice de desgaste em dentina (\% de faces) & $10,59 \pm 9,45^{A}$ & $16,67 \pm 10,79^{B}$ & $17,53 \pm 10,60^{\mathrm{E}}$ \\
\hline Dentes presentes & $25,45 \pm 6,39$ & $25,67 \pm 6,14$ & $25,47 \pm 6,13$ \\
\hline № dentes cariados & $0,30 \pm 0,92$ & $0,55 \pm 1,47$ & $0,20 \pm 0,97$ \\
\hline $\mathrm{PS}(\mathrm{mm})$ & $1,84 \pm 0,47^{A}$ & $2,14 \pm 0,43^{\mathrm{B}}$ & $2,07 \pm 0,40^{\mathrm{E}}$ \\
\hline $\mathrm{NIC}(\mathrm{mm})$ & $1,96 \pm 0,61^{\mathrm{A}}$ & $2,24 \pm 0,53^{B}$ & $2,15 \pm 0,52^{\mathrm{E}}$ \\
\hline ISG (\% de dente) & $24,67 \pm 17,31$ & $26,56 \pm 19,40$ & $22,25 \pm 18,20$ \\
\hline IC (\% de dente) & $23,37 \pm 21,24$ & $19,67 \pm 18,12$ & $20,21 \pm 18,72$ \\
\hline Bolsa 4-5 mm (\% de sítio) & $3,32 \pm 4,05$ & $5,18 \pm 7,97$ & $4,67 \pm 9,01$ \\
\hline Bolsa $\geq 6 \mathrm{~mm}$ (\% de sítio) & $0,72 \pm 2,18$ & $0,93 \pm 2,12$ & $0,75 \pm 1,80$ \\
\hline № fatores para desgaste $(0-7)$ & $1,16 \pm 1,24$ & $1,10 \pm 1,27$ & $1,18 \pm 1,28$ \\
\hline Autopercepção da saúde bucal (0-5) & $3,45 \pm 0,88$ & $3,52 \pm 0,66$ & $3,45 \pm 0,74$ \\
\hline
\end{tabular}

Após um ano de cirurgia, o IMC diminuiu significativamente $(p<0,000)$ para obesidade grau I apresentando média de $32,26 \mathrm{~kg} / \mathrm{m}^{2}$, representada por $36 \%$ dos pacientes. Alcançaram o IMC normal $6 \%$ dos pacientes e $30 \%$ chegaram a sobrepeso. Em seis meses, a redução do IMC foi de $27 \%$, chegando a $35 \%$ em um ano. A perda do excesso de peso foi de $55 \%$ e $71 \%$ após 6 e 12 meses respectivamente.

Os níveis séricos de proteína C-reativa antes da cirurgia bariátrica apresentavam-se altos em $69 \%$ dos pacientes (>0,50 mg/dL). Após 6 meses $15 \%$ dos pacientes continuavam a apresentar níveis altos e após um ano apenas 1 paciente continuou com estes níveis elevados. Este paciente apresentava obesidade mórbida após um ano de cirurgia, embora já tivesse perdido $47 \mathrm{Kg}$.

O percentual de pacientes diabéticos pré cirurgia era de $36 \%$, após 6 meses de cirurgia 5 pacientes apresentaram alto nível de glicose e após 12 meses, apenas 3.

O fluxo salivar, que havia aumentado para $0,96 \mathrm{~mL} / \mathrm{min}$ após 6 meses de cirurgia, voltou a diminuir após um ano $(0,86 \mathrm{~mL} / \mathrm{min})$. 
Após a cirurgia bariátrica, o percentual de faces dentárias com desgaste em esmalte diminuiu de $20 \%$ para $16 \%$, porém aumentou de $11 \%$ para $17 \%$ em dentina.

Quanto à presença de dentes cariados, após 6 meses de cirurgia bariátrica houve aumento discreto na incidência de cárie dentária, voltando a diminuir após 12 meses. Inicialmente $16 \%$ dos pacientes apresentavam pelo menos um dente cariado, após 6 meses aumentou para 28\% ( $p=0,151)$ e diminuiu para 10\% após um ano, sendo a diferença entre as proporções no pós-operatório de 6 e 12 meses estatisticamente significativa $(p=0,024)$.

Em relação à avaliação periodontal, de acordo com a classificação do IPC, houve maior prevalência no grau 2 (cálculo como a pior condição) em obesos antes da cirurgia. Após 6 e 12 meses de cirurgia, o grau 3 passou a ser o mais prevalente (bolsa 4-5 mm como a pior condição periodontal encontrada), como mostra a tabela 5. Esta diferença antes e após a cirurgia bariátrica foi estatisticamente significativa $(p=0,029)$. Porém, considerando a avaliação da boca toda (e não apenas dos dentes índices), a maior prevalência permaneceu no grau 3 nos três períodos avaliados, não mostrando diferença estatística significativa antes e após a cirurgia (Tabela 6).

Tabela 5. Índice periodontal comunitário (IPC), avaliado pelos dentes índices, para pacientes obesos antes e após a cirurgia bariátrica.

\begin{tabular}{l|rrrrrrr|}
\hline & \multicolumn{4}{|c|}{ Avaliação dos dentes índices } \\
\hline \hline & \multicolumn{4}{|c}{ Pré } & \multicolumn{4}{c|}{ Pós 6 meses } & \multicolumn{1}{c|}{ Pós 12 meses } \\
\hline Grau IPC & $\mathrm{n}$ & $(\%)$ & $\mathrm{n}$ & $(\%)$ & $\mathrm{n}$ & $(\%)$ \\
\hline Hígido (0) & 03 & $(6,0)$ & 02 & $(4,0)$ & 03 & $(6,0)$ \\
Sangramento(1) & 04 & $(8,0)$ & 05 & $(10,0)$ & 06 & $(12,0)$ \\
Cálculo (2) & 22 & $(44,0)$ & 10 & $(20,0)$ & 11 & $(22,0)$ \\
Bolsa 4-5mm (3) & 13 & $(26,0)$ & 19 & $(38,0)$ & 17 & $(34,0)$ \\
Bolsa >6mm (4) & 08 & $(16,0)$ & 14 & $(28,0)$ & 13 & $(26,0)$ \\
\hline Total & 50 & $(100,0)$ & 50 & $(100,0)$ & 50 & $(100,0)$ \\
\hline
\end{tabular}

Tabela 6. Índice periodontal comunitário (IPC), avaliado para todos os dentes presentes ("boca toda"), para pacientes obesos antes e após a cirurgia bariátrica.

\begin{tabular}{l|rrrrrr|}
\hline & \multicolumn{6}{|c|}{ Avaliação boca toda } \\
\hline \hline Grau IPC & \multicolumn{4}{|c}{ Pré } & \multicolumn{4}{c|}{ Pós 6 meses } & Pós 12 meses \\
\hline Hígido (0) & $\mathrm{n}$ & $(\%)$ & $\mathrm{n}$ & $(\%)$ & $\mathrm{n}$ & $(\%)$ \\
Sangramento(1) & 01 & $(2,0)$ & 02 & $(4,0)$ & - & $(-)$ \\
Cálculo (2) & 04 & $(8,0)$ & 04 & $(8,0)$ & 04 & $(8,0)$ \\
Bolsa 4-5mm (3) & 10 & $(20,0)$ & 08 & $(16,0)$ & 13 & $(26,0)$ \\
Bolsa >6mm (4) & 24 & $(48,0)$ & 19 & $(38,0)$ & 18 & $(36,0)$ \\
\hline Total & 11 & $(22,0)$ & 17 & $(34,0)$ & 15 & $(30,0)$ \\
\hline
\end{tabular}


A perda de peso não influenciou na autopercepção quanto à saúde bucal e o número de fatores favoráveis ao desgaste permaneceu semelhante, embora a ocorrência de vômitos tenha aumentado de $12 \%$ para $22 \%$ e 25\% após 6 e 12 meses respectivamente, sem significância estatística.

\subsection{BACTÉRIAS PERIODONTOPATOGÊNICAS - RESULTADOS DA Q-PCR}

A concentração média de DNA obtido de 162 amostras foi de 21,57 ng/ $\mathrm{LL}$ variando de 5,8 a 127,9 $\mathrm{ng} / \mathrm{\mu L}$ e a relação 260/280 variou de 1,1 a 1,9, sendo utilizadas apenas as com qualidade na faixa aceitável de 1,5 a 1,9. Após a diluição para valores próximos a $6 \mathrm{ng} / \mu \mathrm{L}$, as concentrações variaram de 4,60 a $9,10 \mathrm{ng} / \mu \mathrm{L}$, apresentando média de 6,97 ng/ $\mu \mathrm{L}$. Para $q$-PCR foram analisadas 120 amostras, 40 por período de avaliação. As 42 amostras excluídas desta análise eram de pacientes que não foram avaliados após cirurgia bariátrica $(n=30)$ ou porque gerou dúvidas quanto à qualidade do DNA $(\mathrm{n}=12)$.

Foram detectadas P.gingivalis, T. forsythia, T. denticola e P. intermedia em $71 \%, 80 \%, 72 \%$ e $85 \%$ dos pacientes obesos antes da cirurgia bariátrica, respectivamente. Após 6 meses de cirurgia, passou para 80\%, 85\%, 75\% e 86\% e após um ano $75 \%, 90 \%, 81 \%$ e $81 \%$ dos pacientes apresentaram respectivamente presença de P.gingivalis, $T$. forsythia, $T$. denticola e $P$. intermedia.

Em relação à quantidade média de $P$.gingivalis houve um aumento estatisticamente significativo após 6 meses de cirurgia $(p=0,028)$, de 15.118 para 89.657 bactérias por $\mu \mathrm{L}$. De 6 para 12 meses, a quantidade diminuiu para 51.170, sem significância estatística.

Quanto às demais bactérias $T$. forsythia, $T$. denticola e P. intermedia, a RQ diminui com o tempo, embora sem significância estatística. Os valores da $R Q$ de cada uma delas estão representados na figura 11 de acordo com o período. 


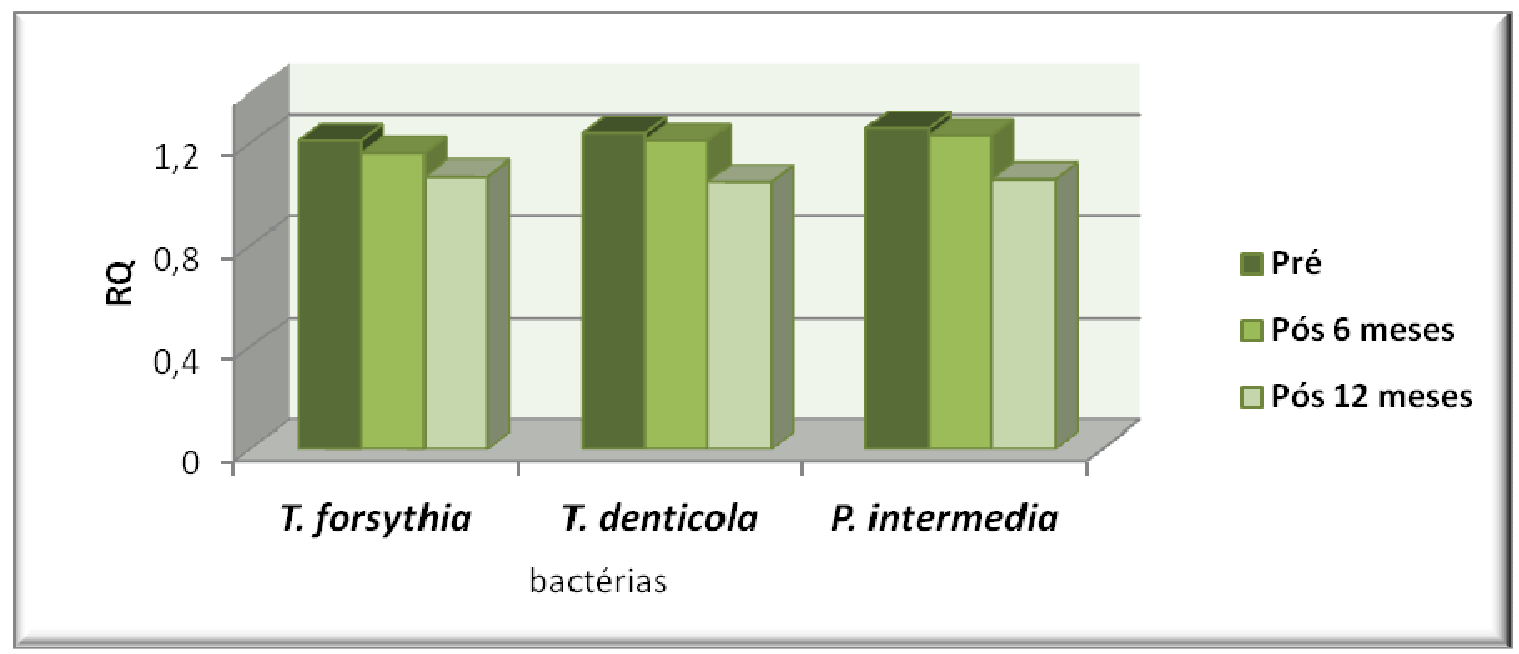

Figura 11 - Gráfico dos valores da quantificação relativa (RQ) das bactérias $T$. forsythia, T. denticola e $P$. intermedia nos 3 períodos avaliados.

As médias das variáveis periodontais (exceto IC e bolsa $\geq 6 \mathrm{~mm}$ ) mostraramse piores na presença da P.gingivalis, entretanto só apresentaram significância estatística quanto à profundidade de sondagem e sangramento gengival no pósoperatório de 12 meses (TABELA 7). A proteína C-reativa também se apresentou mais elevada na presença dessa bactéria nos três períodos, sem significância estatística.

Tabela 7 - Média das variáveis de acordo com a presença (Sim) e ausência (Não) de P.gingivalis comparadas nos 3 períodos avaliados pela ANOVA.

\begin{tabular}{l|rrl|rrl|rrr}
\hline Variáveis & \multicolumn{3}{|c|}{ Pré } & \multicolumn{3}{c|}{ Pós 6 meses } & \multicolumn{3}{c}{ Pós 12 meses } \\
\hline & Sim & Não & $p$ & Sim & Não & $p$ & Sim & Não & $p$ \\
\hline PCR (mg/dL) & 2,01 & 1,60 & 0,629 & 0,40 & 0,38 & 0,913 & 0,23 & 0,16 & 0,421 \\
Glicemia (mg/dL) & 109,45 & 105,69 & 0,771 & 83,70 & 83,11 & 0,912 & 83,80 & 84,40 & 0,914 \\
IMC (kg/m²) & 49,02 & 50,97 & 0,506 & 35,86 & 35,04 & 0,734 & 31,84 & 33,88 & 0,298 \\
PS (mm) & 1,90 & 1,67 & 0,139 & 2,20 & 1,95 & 0,084 & 2,14 & 1,83 & $0,030^{*}$ \\
NIC (mm) & 2,01 & 1,82 & 0,333 & 2,31 & 2,06 & 0,225 & 2,24 & 1,91 & 0,065 \\
ISG (\% de dente) & 26,83 & 18,81 & 0,148 & 27,84 & 23,76 & 0,582 & 25,08 & 9,27 & $0,004^{*}$ \\
IC (\% de dente) & 21,09 & 31,68 & 0,118 & 21,61 & 13,90 & 0,261 & 22,56 & 12,77 & 0,116 \\
Bolsa 4- 5 mm (\% & 3,68 & 2,10 & 0,225 & 5,84 & 3,24 & 0,396 & 5,79 & 0,74 & 0,093 \\
de sítio) & & & & & & & & & \\
Bolsa $\geq 6 \mathrm{~mm}(\%$ & 0,65 & 0,89 & 0,741 & 1,13 & 0,30 & 0,309 & 0,95 & 0,06 & 0,140 \\
de sítio) & & & & & & &
\end{tabular}

*Estatisticamente significativo; PCR = proteína C-reativa; PS = profundidade de sondagem; NIC = nível de inserção clínica; ISG = índice de sangramento gengival; IC = índice de cálculo 
Foi observado que quanto maior a quantidade de $T$. forsythia, maior o índice de bolsa $\geq 6 \mathrm{~mm}$ e maior a profundidade de sondagem no pré $(r=0,453 ; p=0,006$ e $r=0,489 ; p=0,003)$ e no pós-operatório de 6 meses $(r=0,491 ; p=0,004$ e $r=0,371$; $p=0,033)$. No pós-operatório de 12 meses houve correlação positiva com o ISG ( $r=$ $0,384 ; p=0,030)$. A média da glicemia foi significativamente menor na presença de T. forsythia no pré e após um ano de cirurgia bariátrica e a média do ISG no pósoperatório de 12 meses foi maior na presença dessa bactéria (TABELA 8).

Tabela 8 - Média das variáveis de acordo com a presença (Sim) e ausência (Não) de $T$. forsythia comparadas nos 3 períodos avaliados pela ANOVA.

\begin{tabular}{l|ccc|ccc|ccc}
\hline Variáveis & \multicolumn{3}{|c|}{ Pré } & \multicolumn{3}{c|}{ Pós 6 meses } & \multicolumn{3}{c}{ Pós 12 meses } \\
& Sim & Não & $p$ & Sim & Não & $p$ & Sim & Não & $p$ \\
\hline PCR (mg/dL) & 2,14 & 1,28 & 0,476 & 0,22 & 0,12 & 0,561 & 0,22 & 0,20 & 0,872 \\
Glicemia (mg/dL) & 99,76 & 132,28 & $0,031^{*}$ & 80,93 & 79,50 & 0,844 & 81,77 & 97,50 & $0,028^{*}$ \\
IMC (kg/m²) & 49,85 & 45,94 & 0,250 & 35,73 & 43,69 & 0,134 & 31,29 & 34,56 & 0,220 \\
PS (mm) & 1,93 & 1,74 & 0,324 & 2,19 & 2,01 & 0,537 & 2,15 & 1,85 & 0,136 \\
NIC (mm) & 2,05 & 1,94 & 0,681 & 2,28 & 2,02 & 0,472 & 2,26 & 1,86 & 0,103 \\
ISG (\% de dente) & 26,96 & 20,83 & 0,342 & 28,76 & 12,40 & 0,273 & 26,04 & 8,69 & $0,028^{*}$ \\
IC (\% de dente) & 20,39 & 25,23 & 0,546 & 16,72 & 44,07 & $0,023^{*}$ & 19,92 & 8,89 & 0,125 \\
Bolsa 4- 5 mm & 3,88 & 2,76 & 0,500 & 5,81 & 0,83 & 0,431 & 6,24 & 0,56 & 0,200 \\
(\% de sítio) & & & & & & & & & \\
Bolsa $\geq 6 \mathrm{~mm}(\%$ & 0,90 & 0,80 & 0,914 & 1,12 & 0,00 & 0,519 & 1,08 & 0,09 & 0,268 \\
de sítio) & & & &
\end{tabular}

*Estatisticamente significativo; $\mathrm{PCR}=$ proteína C-reativa; $\mathrm{PS}=$ profundidade de sondagem; NIC = nível de inserção clínica; ISG = índice de sangramento gengival; IC = índice de cálculo

Para a $T$. denticola, foi observada correlação positiva com glicemia no pré ( $r=$ 0,389; $p=0,021)$, com índice de bolsa 4-5 mm no pós-operatório de 6 meses ( $r=$ 0,432; $p=0,012)$ e com ISG no pós-operatório de $6(r=0,383 ; p=0,028)$ e 12 meses $(r=0,580 ; p=0,001)$. No pós-operatório de 12 meses também foi observada maior profundidade de sondagem $(r=0,381 ; p=0,031)$ e nível de inserção clínica $(r=0,361$; $\mathrm{p}=0,042$ ) quanto maior o $R Q$ dessa bactéria. Na análise categorizada em presença ou ausência não houve diferenças significativas nas médias das variáveis entre os 3 períodos de avaliação (TABELA 9). 
Tabela 9 - Média das variáveis de acordo com a presença (Sim) e ausência (Não) de T. denticola comparadas nos 3 períodos avaliados pela ANOVA.

\begin{tabular}{l|rrl|rrl|rr|r}
\hline Variáveis & \multicolumn{4}{|c}{ Pré } & \multicolumn{3}{c|}{ Pós 6 meses } & \multicolumn{3}{c}{ Pós 12 meses } \\
\hline & Sim & Não & $p$ & Sim & Não & $p$ & Sim & Não & $p$ \\
\hline PCR (mg/dL) & 1,77 & 2,67 & 0,371 & 0,40 & 0,18 & 0,242 & 0,17 & 0,39 & 0,084 \\
Glicemia (mg/dL) & 99,96 & 122,00 & 0,102 & 81,00 & 80,44 & 0,887 & 85,04 & 85,00 & 0,912 \\
IMC (kg/m²) & 50,30 & 45,82 & 0,139 & 37,23 & 33,03 & 0,135 & 30,85 & 35,35 & 0,085 \\
PS (mm) & 1,93 & 1,79 & 0,426 & 2,22 & 2,06 & 0,301 & 2,12 & 1,98 & 0,409 \\
NIC (mm) & 2,05 & 1,95 & 0,674 & 2,32 & 2,11 & 0,273 & 2,20 & 2,11 & 0,698 \\
ISG (\% de dente) & 26,33 & 24,15 & 0,705 & 31,21 & 17,81 & 0,085 & 23,95 & 19,10 & 0,536 \\
IC (\% de dente) & 22,48 & 18,41 & 0,570 & 20,58 & 11,24 & 0,152 & 19,73 & 11,36 & 0,211 \\
Bolsa 4- 5 mm (\% & 3,97 & 2,83 & 0,443 & 6,19 & 3,58 & 0,436 & 5,30 & 3,27 & 0,603 \\
de sítio) & & & & & & & & & \\
Bolsa $\geq$ 6mm (\% & 0,74 & 1,25 & 0,563 & 1,03 & 1,12 & 0,928 & 0,88 & 0,38 & 0,486 \\
de sítio) & & & & & & & & & \\
\hline
\end{tabular}

$\mathrm{PCR}=$ proteína C-reativa; $\mathrm{PS}=$ profundidade de sondagem; NIC = nível de inserção clínica; ISG = índice de sangramento gengival; $I C$ = índice de cálculo

Quanto à $P$. intermedia, a correlação positiva ocorreu com o índice de bolsa $\geq$ $6 \mathrm{~mm}$ no pré $(r=0,774 ; p=0,000)$ e com índice de sangramento gengival $(r=0,505$; $p=0,003)$, de bolsa $4-5 \mathrm{~mm}(r=0,364 ; p=0,037)$ e profundidade de sondagem $(r=$ $0,365 ; p=0,037)$ no pós-operatório de 6 meses. Quando categorizada em presença e ausência, as médias de PS, NIC e bolsa 4-5 mm no baseline foram maiores na sua presença (TABELA 10).

Tabela 10 - Média das variáveis de acordo com a presença (Sim) e ausência (Não) de $P$. intermedia comparadas nos 3 períodos avaliados pela ANOVA.

\begin{tabular}{|c|c|c|c|c|c|c|c|c|c|}
\hline \multirow[t]{2}{*}{ Variáveis } & \multicolumn{3}{|c|}{ Pré } & \multicolumn{3}{|c|}{ Pós 6 meses } & \multicolumn{3}{|c|}{ Pós 12 meses } \\
\hline & Sim & Não & $p$ & Sim & Não & $p$ & Sim & Não & $p$ \\
\hline PCR (mg/dL) & 1,71 & 3,48 & 0,136 & 0,37 & 0,17 & 0,416 & 0,20 & 0,29 & 0,491 \\
\hline Glicemia (mg/dL) & 105,12 & 110,00 & 0,768 & 80,71 & 81,60 & 0,855 & 83,04 & 92,62 & 0,174 \\
\hline $\operatorname{IMC}\left(\mathrm{kg} / \mathrm{m}^{2}\right)$ & 48,38 & 52,96 & 0,228 & 36,67 & 33,11 & 0,315 & 31,40 & 33,37 & 0,423 \\
\hline $\mathrm{PS}(\mathrm{mm})$ & 1,98 & 1,39 & $0,005^{\star}$ & 2,17 & 2,21 & 0,839 & 2,09 & 2,06 & 0,849 \\
\hline $\mathrm{NIC}(\mathrm{mm})$ & 2,13 & 1,41 & $0,009^{*}$ & 2,27 & 2,22 & 0,815 & 2,18 & 2,16 & 0,939 \\
\hline ISG (\% de dente) & 25,78 & 25,50 & 0,969 & 27,74 & 28,55 & 0,935 & 23,13 & 20,17 & 0,692 \\
\hline IC (\% de dente) & 22,14 & 16,97 & 0,564 & 18,83 & 14,59 & 0,609 & 20,01 & 11,05 & 0,166 \\
\hline $\begin{array}{l}\text { Bolsa 4- } 5 \mathrm{~mm} \text { (\% } \\
\text { de sítio) }\end{array}$ & 4,29 & 0,09 & $0,020^{*}$ & 5,50 & 5,78 & 0,947 & 4,73 & 4,83 & 0,979 \\
\hline $\begin{array}{l}\text { Bolsa } \geq 6 \mathrm{~mm} \text { (\% } \\
\text { de sítio) }\end{array}$ & 1,04 & 0,00 & 0,339 & 0,86 & 2,26 & 0,220 & 0,82 & 0,42 & 0,553 \\
\hline
\end{tabular}

*Estatisticamente significativo; PCR = proteína C-reativa; PS = profundidade de sondagem; NIC = nível de inserção clínica; ISG = índice de sangramento gengival; IC = índice de cálculo 


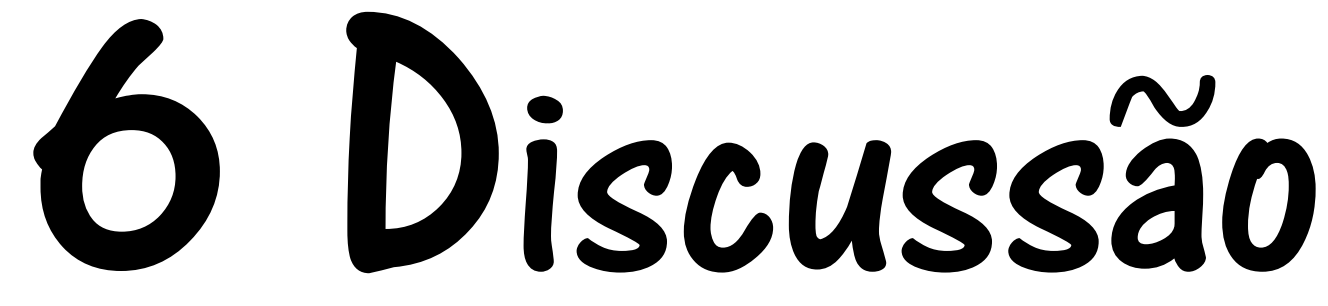





\section{DISCUSSÃO}

\subsection{OBESIDADE E SAÚDE BUCAL}

No presente estudo, a amostra foi composta em sua maioria por mulheres (82\%), o que era esperado, uma vez que $83 \%$ da população que se submete à cirurgia bariátrica são mulheres (HARRIS; BARGER, 2010). Entretanto, a prevalência de obesidade no Brasil é semelhante entre os gêneros (IBGE, 2010). A maior procura pelo tratamento cirúrgico da obesidade por mulheres se deve possivelmente à maior insatisfação com o corpo do que em homens. Além disso, entre elas, o excesso de peso está associado à redução da qualidade de vida, visto que o ideal de corpo feminino é promovido principalmente pela mídia que muitas vezes mostra a imagem de magreza como símbolo da atratividade, beleza e sucesso na vida (BACEVICIENE; REKLAITIENE; TAMOSIUNAS, 2009; KJAERBYETHYGESEN et al., 2004).

Indivíduos obesos têm apresentado níveis séricos de cálcio normais, mas o de PTH elevado, evidenciando a insuficiência de vitamina $D$ e um hiperparatireoidismo secundário (HULTIN et al., 2010; SAHOTA et al., 2004), confrontando com os dados deste estudo. O PTH dos pacientes analisados encontrava-se em níveis considerados normais, apesar de $30 \%$ da amostra apresentá-lo elevado. Estes pacientes necessitam de especial atenção, uma vez que após a cirurgia bariátrica pode ocorrer ainda mais insuficiência de vitamina $D$, devido ao fator disabsortivo da cirurgia, predispondo o indivíduo à doença metabólica óssea (DE PRISCO; LEVINE, 2005; SAHOTA et al., 2004). No presente estudo não foram coletados dados da vitamina $D$ por não constarem na maioria dos prontuários. Por essa razão, optou-se por considerar os níveis séricos de $\mathrm{PTH}$, uma vez que a hipovitaminose D aumenta o PTH e diminui a absorção de cálcio, que para mantê-lo em níveis normais no sangue são retirados dos ossos (SAHOTA et al., 2004).

A associação entre obesidade e proteína C-reativa (BRASIL et al., 2007; COOK et al., 2000; KOPP et al., 2003) foi reforçada neste estudo, visto que no baseline, quanto maior o valor do IMC maior o nível de proteína C-reativa, ou seja, quanto maior o grau de obesidade maior o estado inflamatório sistêmico do 
indivíduo. Isto ocorre porque o tecido adiposo estimula a produção da proteína Creativa no fígado, apresentando-se elevada em condições inflamatórias (VGONTZAS et al., 1997). O motivo de alguns pacientes obesos não apresentarem elevados níveis desta proteína ainda é desconhecido, sendo necessários estudos que determinem que outras características, além da obesidade, são preditivas para sua elevação (ZAGORSKI; PAPA; CHUNG, 2005).

Quanto ao fluxo salivar, diversos são os fatores que desencadeiam a sua diminuição, como desordens autoimune, terapia contra câncer, insuficiência renal, desnutrição, entre outros (DRYMOUTH.INFO), o que não caracterizou os sujeitos desta pesquisa. As causas para o baixo fluxo salivar encontrado não estão claras, visto que os valores do fluxo salivar foram semelhantes entre os grupos (obeso e não obeso), discretamente maiores entre obesos. É possível que o valor do fluxo salivar encontrado esteja subestimado devido à maneira como é realizada sua avaliação, uma vez que os pacientes podem se sentir constrangidos em cuspir durante 5 minutos, podendo mascarar o volume que deveria ter sido obtido. Nenhuma variável estudada apresentou correlação com o fluxo salivar. Embora a hipossalivação seja um fator de risco para ocorrência de problemas bucais (AMERONGEN; VEERMAN, 2002), neste estudo o baixo fluxo salivar não foi determinante para os problemas bucais encontrados.

A maior prevalência de desgaste nos incisivos e na face incisal indica a ocorrência principalmente de atrição, o que pode ser explicada pela alta ocorrência de hábitos, como o bruxismo, observados neste estudo. O bruxismo tem sido reportado como uma manifestação física do stress e da ansiedade (SUTIN et al., 2010) e esta, por sua vez, está intimamente relacionada à obesidade (ATLANTIS; GOLDNEY; WITTERT, 2009).

O avanço da periodontite tem sido associado com o aumento dos níveis séricos de proteína C-reativa (LINDEN et al., 2008; MARIOTTI, 2004; MONTEBUGNOLI et al., 2004; NOACK et al., 2001). No entanto, como todos os pacientes são obesos mórbidos, o fato de ter ou não a doença periodontal não foi suficiente para apresentar diferenças nas médias da proteína C-reativa, embora os obesos que apresentaram sangramento gengival como sua pior condição periodontal (grau 1 do IPC) tiveram maior nível sérico desta proteína. Aliado ao excesso de tecido adiposo, o sangramento gengival como fase aguda da doença periodontal, pode de alguma forma ter contribuído com o aumento destes níveis, 
considerando que a proteína C-reativa é de fase aguda produzida exclusivamente no fígado e seus níveis séricos aumentam rapidamente em resposta a um estímulo inflamatório (HERRON, 2005).

A obesidade é considerada fator de risco para o desenvolvimento da diabetes. Isso tem sido atribuído às concentrações de ácidos graxos livres que estão envolvidos na associação entre a gordura abdominal e resistência à insulina (CNOP et al., 2002). A diabetes por sua vez está relacionada à progressão da doença periodontal devido ao nível elevado de hemoglobina glicosilada que dificulta a ação das células de defesa frente ao processo de infecção (SILVA, 2004). Uma metanálise realizada recentemente concluiu que há evidência suficiente para considerar a diabetes tipo 2 como fator de risco para doença periodontal (CHÁVARRY et al., 2009). Fato este que foi confirmado no presente estudo em que obesos diabéticos, quando comparados aos não diabéticos, apresentaram maior percentual de sítios com bolsa periodontal $\geq 4 \mathrm{~mm}(\mathrm{p}<0,000)$. Não foi critério de exclusão ser portador de diabetes, uma vez que no baseline $36 \%$ dos pacientes avaliados encontravam-se com a glicemia elevada. Independentemente da presença de diabetes, a obesidade mostrou-se relacionada à doença periodontal comparandose com o grupo controle de não obesos. Este fato corrobora com diversos estudos que demonstraram a associação entre obesidade e doença periodontal em adultos (CHAFFEE; WESTON, 2010; EKUNI et al., 2008; KUMAR et al., 2009; SARLATI et al., 2008; SUVAN et al., 2011).

As condições periodontais afetadas nos pacientes obesos podem ter refletido na autopercepção da saúde bucal, que foi melhor entre os indivíduos com peso normal. Além disso, a própria autoestima, que é geralmente baixa entre os obesos (ATLANTIS; GOLDNEY; WITTERT, 2009), pode interferir na percepção subjetiva da saúde bucal (LEÃO; SHEIHAM, 1995; SHEIHAM et al., 2002). A importância deste dado é que a saúde bucal pode contribuir no impacto sobre a qualidade de vida e por mostrar que os pacientes estão cientes que necessitam de tratamento odontológico. 


\subsection{CIRURGIA BARIÁTRICA: CONSEQUÊNCIAS SISTÊMICAS E BUCAIS}

A taxa de mortalidade na amostra foi de $5,5 \%$, considerada alta visto que a taxa de mortalidade devido à cirurgia bariátrica, técnica mista, varia em torno de $1 \%$, inclusive em idosos operados, sendo de $0,5 \%$ em menos de 30 dias de cirurgia e de $1,1 \%$ a taxa de mortalidade tardia, aumentando para uma variação de $0,81 \%$ a 1,25\% para pacientes superobesos (BUCHWALD et al., 2007).

A ocorrência de gestações após a cirurgia bariátrica observada nesta amostra, em que 7,7\% (4 das 52) encontravam-se gestantes entre 6 e 12 meses após a cirurgia, pode ser explicada pelo fato de que após substancial perda de peso, mulheres que antes eram inférteis devido à obesidade, tornam-se capazes de engravidar devido à redução de tecido adiposo que diminui andrógenos circulantes retornando os ciclos ovulatórios, restaurando a fertilidade (HARRIS; BARGER, 2010). Além disso, a perda de peso favorece o desempenho sexual em termos de libido (OLAFSDOTTIR et al., 2006). Estas pacientes foram excluídas da avaliação de um ano devido principalmente às alterações periodontais que podem ocorrer em gestantes (BOGGESS et al., 2011; DIAZ-GUZMAN; CASTELLANOS-SUAREZ, 2004), além da diferença quanto ao IMC.

A cirurgia bariátrica mostrou-se eficiente na perda de peso, visto que a estimada pelo Consenso da Sociedade Americana de Cirurgia Bariátrica é de $65 \%$ a $70 \%$ do excesso de peso e cerca de $35 \%$ do IMC (BUCHWALD, 2005), que foi comprovada no presente estudo devido à similaridade dos percentuais encontrados.

A perda de peso acarretou na diminuição da proteína C-reativa, como observado em outros estudos (AGRAWAL et al., 2009; ZAGORSKI; PAPA; CHUNG, 2005), uma vez que a redução do IMC implicou na redução do tecido adiposo responsável por estimular a produção de proteína C-reativa (AGRAWAL et al., 2009). Por outro lado, baixos níveis desta proteína indicaram redução da inflamação crônica e sistêmica nestes pacientes, podendo proporcionar uma diminuição no risco de doença coronária e acidente vascular cerebral (AGRAWAL et al., 2009).

Sabe-se que o uso de medicamentos para hipertensão, diabetes, dislipidemia e antidepressivos diminui significativamente após 3 meses de cirurgia bariátrica (SEGAL et al., 2009). A remissão da diabetes tipo 2 tem sido contemplada na maioria dos pacientes obesos diabéticos que se submeteram à cirurgia bariátrica (BUCHWALD et al., 2009; SEGAL et al., 2009), como foi observada também neste 
estudo. Esta melhora relacionada à diabetes e a diminuição do uso de medicamentos poderia explicar a discreta melhora do fluxo salivar, visto que a hipossalivação tem sido relacionada à descompensação diabética e à administração de medicamentos antidepressivos (VON BULTZINGSLOWEN et al., 2007).

Outro desfecho avaliado no presente estudo foi a incidência de desgaste dentário, uma vez que após a cirurgia bariátrica ocorrem mudanças significantes nos hábitos alimentares, como a necessidade de ter que mastigar mais, influenciando o aumento da atrição dentária aliada ao processo de erosão decorrente de vômitos frequentes (ARASAKI et al., 2005; BARRON et al., 2003; MACHADO et al., 2007). O desgaste identificado em esmalte antes da cirurgia bariátrica passou a envolver dentina no pós-cirúrgico, demonstrando o aumento na severidade durante o período estudado.

A cárie dentária se constitui em mais uma consequência negativa da cirurgia bariátrica (HAGUE; BAECHLE, 2008; MARSICANO et al., 2011). Sua maior incidência em pacientes bariátricos tem sido atribuída ao aumento do índice de placa, consequente da maior frequência de ingestão alimentar e do baixo fluxo salivar (HAGUE; BAECHLE, 2008). Após 6 meses de cirurgia bariátrica houve um aumento discreto na incidência de dentes cariados e após um ano esse número diminuiu. Provavelmente, devido às orientações e encaminhamento dos pacientes para o atendimento odontológico quando foi identificada presença de cárie na avaliação dos 6 meses após cirurgia. O paciente conhecendo sua condição bucal procurou por tratamento, o que justifica a menor ocorrência na avaliação dos 12 meses.

No presente estudo não foi observada diminuição nos índices para as condições periodontais após a significante perda de peso, embora os fatores de risco para progressão da periodontite relacionados à obesidade tenham reduzido (AL-ZAHRANI; BISSADA; BORAWSKIT, 2003; WOOD; JOHNSON; STRECKFUS, 2003). O aumento na severidade da doença periodontal pelo IPC vai ao encontro dos achados de Marsicano et al. (2011) em que a prevalência de bolsa periodontal e a severidade da doença aumentou em 3 meses após cirurgia bariátrica. A ocorrência desta piora pode estar relacionada com a mudança significante nos hábitos alimentares após a cirurgia bariátrica, entre elas, comer mais vezes durante o dia, mesmo que em menor quantidade, fazendo com que as bactérias causadoras de doenças da boca fiquem em condições favoráveis (HAGUE; BAECHLE, 2008). Outra 
explicação se deve à deficiência nutricional, como a falta de vitamina $D$, frequentemente observada no pós-operatório da cirurgia bariátrica (ELDER; WOLFE, 2007; MALINOWSKI, 2006; PARKES, 2006; TUCKER; SZOMSTEIN; ROSENTHAL, 2007), que pode levar à doença metabólica óssea (DE PRISCO; LEVINE, 2005). A osteoporose é considerada um fator de risco para a doença periodontal, uma vez que pode influenciar a taxa de perda óssea alveolar na periodontite crônica, levando à perda dentária (NICOPOULOU-KARAYIANNI et al., 2009). A perda óssea alveolar foi observada por meio de tomografia computadorizada de feixe cônico em uma paciente submetida à cirurgia bariátrica, apresentando-se aumentada no segundo ano em relação ao primeiro pós-operatório, acompanhada de bolsa periodontal clinicamente observada (DE MOURA-GREC et al., 2012).

Quanto à avaliação periodontal pela classificação de acordo com o IPC, quando se consideraram somente os dentes índices, houve um aumento na severidade após a cirurgia passando de cálculo (código 2), como pior condição, para bolsa 4-5 mm (código 3). No entanto, quando a avaliação considerou todos os dentes presentes para sua classificação, a severidade da doença apresentou-se maior (código 3) antes da cirurgia e assim permaneceu, além de que após um ano de cirurgia bariátrica a condição hígida (código 0) não foi encontrada para nenhum paciente. Portanto, a avaliação periodontal pelo IPC, que adota dentes índices, pode subestimar a situação real (MOURA-GREC et al., 2010) em estudos com tamanho da amostra $\leq 50$, apesar de ser um índice utilizado em grande escala na literatura, uma vez que é preconizado pela OMS (1997).

$\mathrm{Na}$ presença de periodontite, a proteína C-reativa como um marcador inflamatório deveria estar elevada (MARIOTTI, 2004; MONTEBUGNOLI et al., 2004), no entanto, a piora das condições periodontais não foi o suficiente para elevar o seu nível nos indivíduos deste estudo. Níveis elevados desta proteína têm sido encontrados em sujeitos com NIC acima de $3 \mathrm{~mm}$ (NOACK et al., 2001) e a média neste estudo variou de 1,96 a 2,24 mm, que pode justificar o fato da proteína Creativa não ter sido relacionada à condição periodontal.

Os benefícios da cirurgia bariátrica na saúde geral e na qualidade de vida são grandes o suficiente para que os efeitos colaterais relacionados à saúde bucal não sejam percebidos (MARSICANO et al., 2011), visto que a autopercepção da saúde bucal permaneceu semelhante mesmo com a piora das condições periodontais e do desgaste dentário. 


\subsection{BACTÉRIAS PERIODONTOPATOGÊNICAS}

O presente estudo buscou avaliar, por meio da quantificação de DNA (q$\mathrm{PCR}$ ), a presença de DNA de quatro importantes periodontopatógenos ( $P$. gingivalis, $T$. forsythia, $T$. denticola e $P$. intermedia) no fluido gengival, por estarem entre os maiores agentes etiológicos da periodontite (BRENNAN et al., 2007; FENG; WEINBERG, 2006), com alto nível de destruição do tecido periodontal (RIEP et al., 2009) e que levam à expressão de citocinas pró-inflamatórias (TROMBONE et al., 2009).

Quanto à qualidade do DNA bacteriano extraído, em geral as amostras apresentaram as frações de DNA com qualidade preconizada para uso. Os valores acima de 1,9 sugerem degradação de DNA e os menores que 1,5 contaminação com RNA e com polissacarídeos (GONZALEZ-MENDOZA et al., 2010; KIM; BYUN; LEE, 2005; WILLIAMS; SLATKO; MCCARREY, 2007). A concentração média de DNA $(21,57 \mathrm{ng} / \mu \mathrm{L})$ verificado no espectrofotometro foi semelhante aos dados apresentados na literatura científica (LEE et al., 2010).

A reação em cadeia da polimerase em tempo real, chamada de q-PCR, é uma técnica que revoluciona a quantificação de DNA, uma vez que detecta o alvo desde a sua primeira amplificação até a quantidade de produto final acumulado ao término dos ciclos de reação. Por isso ela é indicada para detectar e quantificar o alvo com precisão (APPLIED-BIOSYSTEMS, 2008; LIFE-TECHNOLOGIES, 2011). A amplificação dos segmentos de DNA bacteriano foi realizada por meio da q-PCR, baseada na fluorescência, neste caso emitida pelo uso do SYBR Green ${ }^{\circledR}$ que tem a vantagem de ter custo acessível, boa sensibilidade e fácil utilização (NOVAIS; ALVES; SILVA, 2004).

No baseline, a P.gingivalis não foi identificada em apenas $29 \%$ dos pacientes. Destes, dois passaram a apresentar esta bactéria, provavelmente devido à piora das condições periodontais observadas após a cirurgia bariátrica. Este fato foi reforçado pelo aumento desta bactéria em quantidade, apresentando em número 6 vezes maior no pós-operatório de 6 meses. Pataro (2010) também observou maior quantidade de $P$. gingivalis no grupo pós-operatório de cirurgia bariátrica e afirmou não existir mecanismos concretos que expliquem este achado, uma vez que a redução de peso diminui a resposta inflamatória (PATARO, 2010). No pós-operatório de 12 meses, embora sua presença tenha sido relacionada à PS e ISG, foi 
observada diminuição de $43 \%$ na quantidade de P.gingivalis que pode ter sido influenciada pela melhora nas condições sistêmicas (resposta inflamatória) relacionadas à maior perda de excesso de peso, apesar das condições periodontais terem piorado.

A atribuição da periodontite como alto risco para doenças cardiovasculares está nos efeitos desencadeados pelos patógenos na infecção, que incluem distúrbios do metabolismo lipídico e consequente elevação das citocinas próinflamatórias, provocando a maioria das complicações vasculares (WU et al., 2000), além da bacteremia, visto que periodontopatógenos têm sido encontrados em placas de ateroma (HARASZTHY et al., 2000). A presença da P.gingivalis desfavorece a diminuição do risco de doenças cardiovasculares que se deseja alcançar com o tratamento da obesidade, visto que além da bacteremia, a liberação de citocinas inflamatórias desencadeadas pelo patógeno periodontal estão envolvidas no processo da aterogênese (HARASZTHY et al., 2000). Fato este que mostra a importância da prevenção e tratamento da infecção periodontal nestes pacientes para contribuir com a redução da morbi-mortalidade relacionada à doença cardiovascular.

Forte relação entre o aumento dos níveis séricos da proteína C-reativa e a presença de $P$. gingivalis no fluido subgengival tem sido observada e justificada por sua ação de destruição do tecido periodontal que induz a inflamação sistêmica e a resposta imune (NOACK et al., 2001). No presente estudo a proteína C-reativa esteve aumentada na presença deste patógeno, embora não significativamente.

O número de pacientes com as bactérias T.forsythia e T.denticola aumentou discretamente com o tempo, mas as bactérias diminuíram em quantidade relativa ( $p>0,050$ ). Os achados clínicos encontrados contrastam com este resultado, uma vez que a progressão da doença periodontal deveria elevar a quantidade de bactérias do complexo vermelho (FERREIRA et al., 2008; SAKAMOTO et al., 2002; SOCRANSKY et al., 1998; TROMBONE et al., 2009; YOSHIDA et al., 2004).

A $T$. forsythia esteve associada à perda óssea alveolar em mulheres com sobrepeso no estudo de Brennan et al. (2007). No presente estudo foi observada tendência a esses achados, visto que após a cirurgia bariátrica, foi encontrada menor média do IMC nos pacientes em que essa bactéria foi detectada, embora sem significância estatística. 
A correlação positiva encontrada entre a T.denticola e o nível de glicose no baseline pode ser justificada pela presença dessa bactéria em bolsas mais profundas (YOSHIDA et al., 2004), uma vez que os diabéticos apresentaram maior profundidade de sondagem do que os obesos não diabéticos.

O número de indivíduos portadores de $P$. intermedia diminuiu, bem como a quantidade relativa delas no pós-operatório de 12 meses, embora não significativamente. $O$ aumento na severidade da doença periodontal pode ter contribuído para que as bactérias do complexo vermelho se destacassem mais que a $P$. intermedia que faz parte do complexo laranja (SOCRANSKY et al., 1998).

Brennan et al. (2007) identificaram a presença de $P$. Intermedia e T.forsythia em níveis severos de perda óssea. No presente estudo essas bactérias estiveram presentes em piores condições periodontais, ou seja, estiveram relacionadas à maior profundidade de sondagem, principalmente no baseline.

Exceto a $P$. gingivalis, as bactérias analisadas diminuíram discretamente ao invés de acompanhar o aumento da doença observado nos parâmetros clínicos, o que indica que consequências sistêmicas negativas da cirurgia bariátrica, como a deficiente absorção de cálcio, podem ter realmente influenciado na piora das condições periodontais e a presença das bactérias, desde o pré-operatório, contribuiu para acelerar este processo. Outros estudos relacionando condições sistêmicas e bucais em pacientes submetidos à cirurgia bariátrica deverão ser conduzidos para esclarecer melhor a diferença entre a avaliação microbiológica e a clínica.

\subsection{IMPLICAÇÕES CLÍNICAS}

O acompanhamento odontológico para pacientes bariátricos desde o préoperatório é fundamental para proporcionar melhor recuperação e adaptação mastigatória durante todo o pós-operatório, contribuir no tratamento e na prevenção das lesões da cavidade bucal, proporcionando benefícios à saúde bucal e geral destes pacientes, além de diminuir os riscos de complicações cardiovasculares relacionados à bacteremia.

A resposta ao tratamento periodontal é melhor quanto maior a perda de peso (LAKKIS et al., 2011), por isso o acompanhamento pré e pós-cirúrgico do paciente 
pelo cirurgião-dentista é imprescindível e sua atuação na equipe multiprofissional deveria constar no protocolo de atenção à saúde dos pacientes bariátricos.

Enquanto isso não acontece, é essencial que os profissionais da saúde envolvidos no tratamento destes pacientes tenham conhecimento do impacto causado pelos efeitos colaterais da cirurgia bariátrica na saúde bucal, para orientar e encaminhar estes pacientes ao profissional da odontologia.

Este profissional, por sua vez, também deve estar atualizado sobre essas implicações da cirurgia da obesidade na condição de saúde bucal, bem como conhecer o histórico médico e psicossocial do paciente bariátrico que poderá aparecer no consultório odontológico, a fim de assegurar o tratamento e a prevenção eficazes das doenças bucais (MORAVEC; BOYD, 2011).

Cuidados com a saúde bucal desempenham importante papel no estado nutricional (MARCENES et al., 2003), uma vez que uma boa mastigação associada a hábitos nutricionais saudáveis são fundamentais para a manutenção dos benefícios alcançados sistemicamente com a cirurgia bariátrica. 


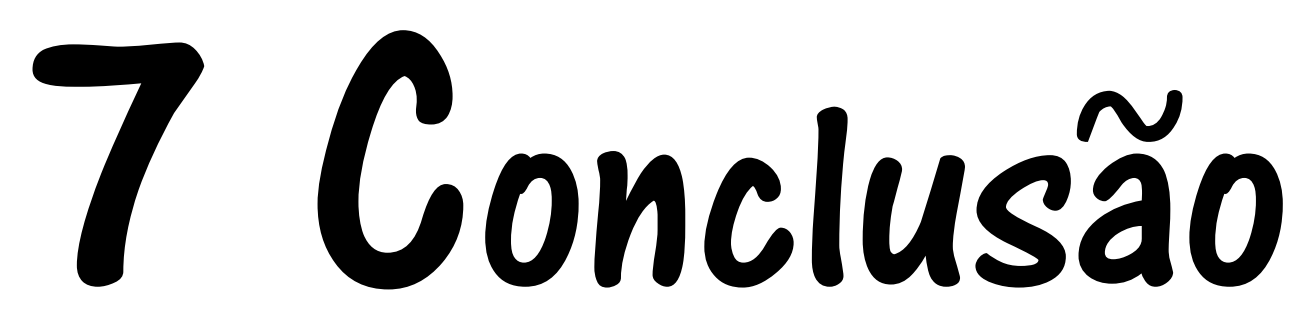





\section{CONCLUSÃO}

A cirurgia bariátrica promoveu impacto negativo nas condições de saúde bucal, especialmente doença periodontal e desgaste dentário. A quantificação das bactérias periodontopatogênicas pela q-PCR mostrou alterações durante os três períodos, sendo que a P.gingivalis acompanhou o aumento na severidade da doença periodontal.

Para as diferentes propostas foram obtidas as seguintes conclusões:

- Os problemas bucais hipossalivação, desgaste dentário e doença periodontal mostraram-se presentes nos obesos e persistiram após a cirurgia bariátrica;

- Os níveis de glicose e proteína C-reativa apresentaram-se elevados nos obesos, no entanto diminuíram significativamente após a cirurgia bariátrica. Os pacientes obesos diabéticos apresentaram maior severidade da doença periodontal;

- A autopercepção da saúde bucal foi pior nos obesos quando comparados aos não obesos. Não houve alteração na autopercepção dos pacientes após cirurgia bariátrica, mesmo com a piora das condições bucais;

- Pacientes obesos apresentaram maior prevalência de sangramento gengival, cálculo dentário e bolsa de 4-5 mm comparados ao grupo controle (não obesos);

- A quantidade de P. gingivalis aumentou, enquanto a de T.forsythia, T.denticola e $P$. intermedia diminuiu após cirurgia bariátrica. As bactérias periodontopatogênicas não mostraram associação com IMC e somente a $P$. gingivalis apresentou associação significativa com o tempo de pós-operatório. 



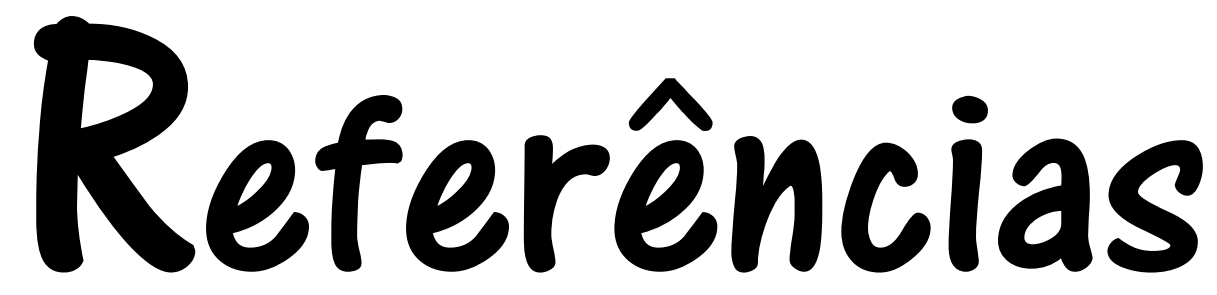





\section{REFERÊNCIAS}

Agrawal V, Krause KR, Chengelis DL, Zalesin KC, Rocher LL, McCullough PA. Relation between degree of weight loss after bariatric surgery and reduction in albuminuria and C-reactive protein. Surg Obes Relat Dis. 2009 Jan-Feb;5(1):20-6.

Ainamo J, Barmes D, Beagrie G, Cutress T, Martin J, Sardo-Infirri J. Development of the World Health Organization (WHO) community periodontal index of treatment needs (CPITN). Int Dent J. 1982 Sep;32(3):281-91.

Al-Zahrani MS, Bissada NF, Borawskit EA. Obesity and periodontal disease in young, middle-aged, and older adults. J Periodontol. 2003 May;74(5):610-5.

Amerongen AV, Veerman EC. Saliva--the defender of the oral cavity. Oral Dis. 2002 Jan;8(1):12-22.

Applied-Biosystems. Guide to performing relative quantitation of gene expression using Real-Time quantitative PCR. 2008 [acesso em 2012 Fev 2]; Disponível em: $<$ http://www3.appliedbiosystems.com/cms/groups/mcb support/documents/generald ocuments/cms 042380.pdf>

Arasaki CH, Del Grande JC, Yanagita ET, Alves AK, Oliveira DR. Incidence of regurgitation after the banded gastric bypass. Obes Surg. 2005 NovDec;15(10):1408-17.

Ashimoto A, Chen C, Bakker I, Slots J. Polymerase chain reaction detection of 8 putative periodontal pathogens in subgingival plaque of gingivitis and advanced periodontitis lesions. Oral Microbiol Immunol. 1996 Aug;11(4):266-73.

Atlantis E, Goldney RD, Wittert GA. Obesity and depression or anxiety [editorial]. BMJ. 2009;339:b3868.

Baceviciene M, Reklaitiene R, Tamosiunas A. Effect of excess body weight on quality of life and satisfaction with body image among middle-aged Lithuanian inhabitants of Kaunas city. Medicina (Kaunas). 2009;45(7):565-73.

Balsa JA, Botella-Carretero JI, Peromingo R, Zamarron I, Arrieta F, Munoz-Malo T, et al. Role of calcium malabsorption in the development of secondary hyperparathyroidism after biliopancreatic diversion. J Endocrinol Invest. 2008 Oct;31(10):845-50.

Barron RP, Carmichael RP, Marcon MA, Sandor GK. Dental erosion in gastroesophageal reflux disease. J Can Dent Assoc. 2003 Feb;69(2):84-9.

Bastos AA, Falcão CB, Pereira ALA, Pereira AFV, Alves CMC. Obesity and periodontal desease Brazilian Research in Pediatric Dentistry and Integrated Clinic. 2005;5(3):275-9.

Belafsky PC, Rees CJ, Rodriguez K, Pryor JS, Katz PO. Esophagopharyngeal reflux. Otolaryngol Head Neck Surg. 2008 Jan;138(1):57-61. 
Biccas BN, Lemme EM, Abrahao LJ, Jr., Aguero GC, Alvariz A, Schechter RB. [Higher prevalence of obesity in erosive gastroesophageal reflux disease]. Arq Gastroenterol. 2009 Jan-Mar;46(1):15-9.

Boggess KA, Espinola JA, Moss K, Beck J, Offenbacher S, Camargo CA, Jr. Vitamin $\mathrm{D}$ status and periodontal disease among pregnant women. J Periodontol. 2011 Feb;82(2):195-200.

Bouldin MJ, Ross LA, Sumrall CD, Loustalot FV, Low AK, Land KK. The effect of obesity surgery on obesity comorbidity. Am J Med Sci. 2006 Apr;331(4):183-93.

Brasil AR, Norton RC, Rossetti MB, Leao E, Mendes RP. C-reactive protein as an indicator of low intensity inflammation in children and adolescents with and without obesity. J Pediatr (Rio J). 2007 Sep-Oct;83(5):477-80.

Brennan RM, Genco RJ, Wilding GE, Hovey KM, Trevisan M, Wactawski-Wende J. Bacterial species in subgingival plaque and oral bone loss in postmenopausal women. J Periodontol. 2007 Jun;78(6):1051-61.

Breton J, Naranjo S, Laborda S, Ruesca P, Hernández R. Effectiveness and complications of bariatric surgery in the treatment of morbid obesity. Nutr Hosp. 2005 Nov;20(6):409-14 .

Brolin RE. Bariatric surgery and long-term control of morbid obesity. Jama. 2002 Dec 11;288(22):2793-6.

Buchwald $\mathrm{H}$. Bariatric surgery for morbid obesity: health implications for patients, health professionals, and third-party payers. J Am Coll Surg. 2005 Apr;200(4):593604.

Buchwald H, Avidor Y, Braunwald E, Jensen MD, Pories W, Fahrbach K, et al. Bariatric surgery: a systematic review and meta-analysis. Jama. 2004 Oct 13;292(14):1724-37.

Buchwald H, Estok R, Fahrbach K, Banel D, Jensen MD, Pories WJ, et al. Weight and type 2 diabetes after bariatric surgery: systematic review and meta-analysis. Am J Med. 2009 Mar;122(3):248-56 e5.

Buchwald H, Estok R, Fahrbach K, Banel D, Sledge I. Trends in mortality in bariatric surgery: a systematic review and meta-analysis. Surgery. 2007 Oct;142(4):621-32; discussion 32-5.

Buchwald H, Williams SE. Bariatric surgery worldwide 2003. Obes Surg. 2004 Oct;14(9):1157-64.

Capella RF, Capella JF, Mandec H, Nath P. Vertical Banded Gastroplasty-Gastric Bypass: preliminary report. Obes Surg. 1991 Dec;1(4):389-95.

Cebrian-Carretero JL, Lopez-Arcas-Calleja JM. Gastroesophageal reflux diagnosed by occlusal splint tintion. Med Oral Patol Oral Cir Bucal. 2006 Jan;11(1):E26-8. 
Ceneviva R, Silva G, Viegas M, Sankarankutty A, Chueire F. Cirurgia bariátrica e apnéia do sono. Medicina (Ribeirão Preto). 2006;39(2):235-45.

Chaffee BW, Weston SJ. Association between chronic periodontal disease and obesity: a systematic review and meta-analysis. J Periodontol. 2010 Dec;81(12):1708-24.

Chávarry NG, Vettore MV, Sansone C, Sheiham A. The relationship between diabetes mellitus and destructive periodontal disease: a meta-analysis. Oral Health Prev Dent. 2009;7(2):107-27.

Chaves ES, Jeffcoat MK, Ryerson CC, Snyder B. Persistent bacterial colonization of Porphyromonas gingivalis, Prevotella intermedia, and Actinobacillus actinomycetemcomitans in periodontitis and its association with alveolar bone loss after 6 months of therapy. J Clin Periodontol. 2000 Dec;27(12):897-903.

Cnop M, Landchild MJ, Vidal J, Havel PJ, Knowles NG, Carr DR, et al. The concurrent accumulation of intra-abdominal and subcutaneous fat explains the association between insulin resistance and plasma leptin concentrations : distinct metabolic effects of two fat compartments. Diabetes. 2002 Apr;51(4):1005-15.

Cook DG, Mendall MA, Whincup PH, Carey IM, Ballam L, Morris JE, et al. C-reactive protein concentration in children: relationship to adiposity and other cardiovascular risk factors. Atherosclerosis. 2000 Mar;149(1):139-50.

Correa MC, Lerco MM, Henry MA. Estudo de alterações na cavidade oral em pacientes com doença do refluxo gastroesofágico. Arq Gastroenterol. 2008 AprJun;45(2):132-6.

Curtis MA, Slaney JM, Aduse-Opoku J. Critical pathways in microbial virulence. J Clin Periodontol. 2005;32 Suppl 6:28-38.

de Francischi RPP, Pereira LO, Freitas CS, Klopfer M, Santos RC, Vieira P, et al. Obesidade: atualização sobre sua etiologia, morbidade e tratamento. Rev Nutr. 2000;13(1):17-28.

de Moura-Grec PG, Marsicano JA, Rodrigues LM, de Carvalho Sales-Peres SH. Alveolar bone loss and periodontal status in a bariatric patient: a brief review and case report. Eur J Gastroenterol Hepatol. 2012 Jan;24(1):84-9.

De Prisco C, Levine SN. Metabolic bone disease after gastric bypass surgery for obesity. Am J Med Sci. 2005 Feb;329(2):57-61.

Deitel M. Bariatric surgery, proton pump inhibitors, and possibility of osteoporosis. Surg Obes Relat Dis. 2010 Jul-Aug;6(4):461-2.

Diaz-Guzman LM, Castellanos-Suarez JL. Lesions of the oral mucosa and periodontal disease behavior in pregnant patients. Med Oral Patol Oral Cir Bucal. 2004 Nov-Dec;9(5):434-7; 0-3. 
Diaz-Lobato S, Navarro JG, Perez-Rodriguez E. Dramatic functional improvement following bariatric surgery in a patient with pulmonary arterial hypertension and morbid obesity. Chest. 2008 Sep;134(3):670; author reply -1.

Drymouth.info. [acesso em 2012 Jan 20]; Disponível em: <http://www.drymouth.info/consumer/WhatCausesDM.asp $>$

Ebersole JL, Machen RL, Steffen MJ, Willmann DE. Systemic acute-phase reactants, C-reactive protein and haptoglobin, in adult periodontitis. Clin Exp Immunol. 1997 Feb;107(2):347-52.

Eccles JD, Jenkins WG. Dental erosion and diet. Journal of dentistry. 1974 Jul;2(4):153-9.

Ekuni D, Yamamoto T, Koyama R, Tsuneishi M, Naito K, Tobe K. Relationship between body mass index and periodontitis in young Japanese adults. J Periodontal Res. 2008 Aug;43(4):417-21.

El-Serag HB, Satia JA, Rabeneck L. Dietary intake and the risk of gastrooesophageal reflux disease: a cross sectional study in volunteers. Gut. 2005 Jan;54(1):11-7.

Elder KA, Wolfe BM. Bariatric surgery: a review of procedures and outcomes. Gastroenterology. 2007 May;132(6):2253-71.

Estrela CR, Pimenta FC, Alencar AH, Ruiz LF, Estrela C. Detection of selected bacterial species in intraoral sites of patients with chronic periodontitis using multiplex polymerase chain reaction. J Appl Oral Sci. 2010 Jul-Aug;18(4):426-31.

Fandiño J, Benchimol AK, Coutinho WF, Appolinário JC. Cirurgia Bariátrica: aspectos clínicos-cirúrgico e psiquiátricos. Revista de Psiquiatria do Rio Grande do Sul. 2004;26(1):47-51.

Feng Z, Weinberg A. Role of bacteria in health and disease of periodontal tissues. Periodontol 2000. 2006;40:50-76.

Fenoll-Palomares C, Munoz Montagud JV, Sanchiz V, Herreros B, Hernandez V, Minguez $\mathrm{M}$, et al. Unstimulated salivary flow rate, $\mathrm{pH}$ and buffer capacity of saliva in healthy volunteers. Rev Esp Enferm Dig. 2004 Nov;96(11):773-83.

Ferreira SB, Jr., Trombone AP, Repeke CE, Cardoso CR, Martins W, Jr., Santos CF, et al. An interleukin-1beta (IL-1beta) single-nucleotide polymorphism at position 3954 and red complex periodontopathogens independently and additively modulate the levels of IL-1beta in diseased periodontal tissues. Infect Immun. 2008 Aug;76(8):3725-34.

Fleet JC, Gliniak C, Zhang Z, Xue Y, Smith KB, McCreedy R, et al. Serum metabolite profiles and target tissue gene expression define the effect of cholecalciferol intake on calcium metabolism in rats and mice. J Nutr. 2008 Jun;138(6):1114-20.

Flegal KM, Carroll MD, Ogden CL, Curtin LR. Prevalence and trends in obesity among US adults, 1999-2008. Jama. 2010 Jan 20;303(3):235-41. 
Fleischer J, Stein EM, Bessler M, Della Badia M, Restuccia N, Olivero-Rivera L, et al. The decline in hip bone density after gastric bypass surgery is associated with extent of weight loss. J Clin Endocrinol Metab. 2008 Oct;93(10):3735-40.

Fobi M. Banded gastric bypass: combining two principles. Surg Obes Relat Dis. 2005 May-Jun;1(3):304-9.

Gonzalez-Mendoza D, Argumedo-Delira R, Morales-Trejo A, Pulido-Herrera A, Cervantes-Diaz L, Grimaldo-Juarez O, et al. A rapid method for isolation of total DNA from pathogenic filamentous plant fungi. Genet Mol Res. 2010;9(1):162-6.

Grippo JO. Abfractions: a new classification of hard tissue lesions of teeth. J Esthet Dent. 1991 Jan-Feb;3(1):14-9.

Grippo JO, Simring M. Dental 'erosion' revisited. J Am Dent Assoc. 1995 May;126(5):619-20, 23-4, 27-30.

Hague AL, Baechle M. Advanced caries in a patient with a history of bariatric surgery. J Dent Hyg. 2008 Spring;82(2):22.

Haraszthy VI, Zambon JJ, Trevisan M, Zeid M, Genco RJ. Identification of periodontal pathogens in atheromatous plaques. J Periodontol. 2000 Oct;71(10):1554-60.

Harris AA, Barger MK. Specialized care for women pregnant after bariatric surgery. J Midwifery Womens Health. 2010 Nov-Dec;55(6):529-39.

Heling I, Sgan-Cohen HD, Itzhaki M, Beglaibter N, Avrutis O, Gimmon Z. Dental complications following gastric restrictive bariatric surgery. Obes Surg. 2006 Sep;16(9):1131-4.

Herron DM. C-reactive protein and adiposity: obesity as a systemic inflammatory state. Surg Obes Relat Dis. 2005 May-Jun;1(3):385-6.

Hultin H, Edfeldt K, Sundbom M, Hellman P. Left-shifted relation between calcium and parathyroid hormone in obesity. J Clin Endocrinol Metab. 2010 Aug;95(8):397381.

IBGE. Instituto Brasileiro de Geografia e Estatística. 2010 [acesso em 2012 Jan 15]; Disponível em: $<$ http://www.ibge.gov.br/home/presidencia/noticias/noticia visualiza.php?id noticia=1 699\&id pagina $=1>$

Ito T, Komiya-Ito A, Arataki T, Furuya Y, Yajima Y, Yamada S, et al. Relationship between antimicrobial protein levels in whole saliva and periodontitis. J Periodontol. 2008 Feb;79(2):316-22.

James PT, Rigby N, Leach R. The obesity epidemic, metabolic syndrome and future prevention strategies. Eur J Cardiovasc Prev Rehabil. 2004 Feb;11(1):3-8. 
Kim HS, Byun SH, Lee BM. Effects of chemical carcinogens and physicochemical factors on the UV spectrophotometric determination of DNA. J Toxicol Environ Health A. 2005 Dec 10;68(23-24):2081-95.

Kjaerbye-Thygesen A, Munk C, Ottesen B, Kruger Kjaer S. Why do slim women consider themselves too heavy? A characterization of adult women considering their body weight as too heavy. Int J Eat Disord. 2004 Apr;35(3):275-85.

Kopelman PG. Obesity as a medical problem. Nature. 2000 Apr 6;404(6778):635-43.

Kopp HP, Kopp CW, Festa A, Krzyzanowska K, Kriwanek S, Minar E, et al. Impact of weight loss on inflammatory proteins and their association with the insulin resistance syndrome in morbidly obese patients. Arterioscler Thromb Vasc Biol. 2003 Jun 1;23(6):1042-7.

Korenkov M, Sauerland S, Junginger T. Surgery for obesity. Curr Opin Gastroenterol. 2005 Nov;21(6):679-83.

Kumar S, Dagli RJ, Dhanni C, Duraiswamy P. Relationship of body mass index with periodontal health status of green marble mine laborers in Kesariyaji, India. Braz Oral Res. 2009 Oct-Dec;23(4):365-9.

Lakkis D, Bissada NF, Saber A, Khaitan L, Palomo L, Narendran S, et al. Response to Periodontal Therapy in Subjects Who Had Weight Loss Following Bariatric Surgery and Obese Counterparts: A Pilot Study. J Periodontol. 2011 Oct 20.

Landis JR, Koch GG. The measurement of observer agreement for categorical data. Biometrics. 1977 Mar;33(1):159-74.

Leão A, Sheiham A. Relation between clinical dental status and subjective impacts on daily living. J Dent Res. 1995 Jul;74(7):1408-13.

Lee JH, Park Y, Choi JR, Lee EK, Kim HS. Comparisons of three automated systems for genomic DNA extraction in a clinical diagnostic laboratory. Yonsei Med J. 2010 Jan 31;51(1):104-10.

Levitch LC, Bader JD, Shugars DA, Heymann HO. Non-carious cervical lesions. Journal of dentistry. 1994 Aug;22(4):195-207.

Life-Technologies. Treinamento PCR em Tempo Real - Apostila Texto. Centro de treinamento Life Technologies Brasil, São Paulo. 2011.

Linden GJ, McClean K, Young I, Evans A, Kee F. Persistently raised C-reactive protein levels are associated with advanced periodontal disease. J Clin Periodontol. 2008 Sep;35(9):741-7.

Litonjua LA, Andreana S, Bush PJ, Cohen RE. Tooth wear: attrition, erosion, and abrasion. Quintessence Int. 2003 Jun;34(6):435-46.

Machado NA, Fonseca RB, Branco CA, Barbosa GA, Fernandes Neto AJ, Soares CJ. Dental wear caused by association between bruxism and gastroesophageal reflux disease: a rehabilitation report. J Appl Oral Sci. 2007 Aug;15(4):327-33. 
Madan AK, Orth WS, Tichansky DS, Ternovits CA. Vitamin and trace mineral levels after laparoscopic gastric bypass. Obes Surg. 2006 May;16(5):603-6.

Magdaleno R, Jr., Chaim EA, Pareja JC, Turato ER. The Psychology of Bariatric Patient: What Replaces Obesity? A Qualitative Research with Brazilian Women. Obes Surg. 2009 Mar 21.

Malinowski SS. Nutritional and metabolic complications of bariatric surgery. Am J Med Sci. 2006 Apr;331(4):219-25.

Marcenes W, Steele JG, Sheiham A, Walls AW. The relationship between dental status, food selection, nutrient intake, nutritional status, and body mass index in older people. Cad Saude Publica. 2003 May-Jun;19(3):809-16.

Mariotti A. Laboratory testing of patients with systemic conditions in periodontal practice. Periodontol 2000. 2004;34:84-108.

Marsicano J. Avaliação das condições bucais de pacientes obesos e de submetidos à cirurgia bariátrica [dissertação]. Bauru: Faculdade de Odontologia de Bauru, Universidade de São Paulo; 2008.

Marsicano JA, Grec PG, Belarmino LB, Ceneviva R, Peres SH. Interfaces between bariatric surgery and oral health: a longitudinal survey. Acta Cir Bras. 2011;26 Suppl 2:79-83.

Moazzez R, Bartlett D, Anggiansah A. Dental erosion, gastro-oesophageal reflux disease and saliva: how are they related? Journal of dentistry. 2004 Aug;32(6):48994.

Modeer T, Blomberg CC, Wondimu B, Julihn A, Marcus C. Association between obesity, flow rate of whole saliva, and dental caries in adolescents. Obesity (Silver Spring). 2010 Dec;18(12):2367-73.

Montebugnoli L, Servidio D, Miaton RA, Prati C, Tricoci P, Melloni C. Poor oral health is associated with coronary heart disease and elevated systemic inflammatory and haemostatic factors. J Clin Periodontol. 2004 Jan;31(1):25-9.

Moravec LJ, Boyd LD. Bariatric surgery and implications for oral health: a case report. J Dent Hyg. 2011 Summer;85(3):166-76.

Moura-Grec PG, Marsicano JA, Leite CVS, Ceneviva R, Sales-Peres SHC. Prevalência e severidade da doença periodontal em indivíduos obesos: comparação de dois métodos. Brazilian Oral Research 2010; 24:226-. Presented at 27th SBPqO Annual Meeting; 2010 Águas de Lindóia, SP

Need AG, O'Loughlin PD, Morris HA, Horowitz M, Nordin BE. The effects of age and other variables on serum parathyroid hormone in postmenopausal women attending an osteoporosis center. J Clin Endocrinol Metab. 2004 Apr;89(4):1646-9.

Nicopoulou-Karayianni K, Tzoutzoukos P, Mitsea A, Karayiannis A, Tsiklakis K, Jacobs R, et al. Tooth loss and osteoporosis: the OSTEODENT Study. J Clin Periodontol. 2009 Mar;36(3):190-7. 
Noack B, Genco RJ, Trevisan M, Grossi S, Zambon JJ, De Nardin E. Periodontal infections contribute to elevated systemic C-reactive protein level. J Periodontol. 2001 Sep;72(9):1221-7.

Noiri Y, Li L, Yoshimura F, Ebisu S. Localization of Porphyromonas gingivaliscarrying fimbriae in situ in human periodontal pockets. J Dent Res. 2004 Dec;83(12):941-5.

Novais CM, Alves MP, Silva FF. PCR em tempo real. Uma inovação tecnológica da Reação em Cadeia da Polimerase (PCR). Rev Biotec Cien Desenv. 2004 juldez;33:10-3.

Olafsdottir AS, Skuladottir GV, Thorsdottir I, Hauksson A, Steingrimsdottir L. Maternal diet in early and late pregnancy in relation to weight gain. Int J Obes (Lond). 2006 Mar;30(3):492-9.

Oliveira V, Linardi R, Azevedo A. Cirurgia bariátrica: aspectos psicológicos e psiquiátricos. Rev Psiq Clin. 2004;31(4):199-201.

Page RC, Kornman KS. The pathogenesis of human periodontitis: an introduction. Periodontol 2000. 1997 Jun;14:9-11.

Parkes E. Nutritional management of patients after bariatric surgery. Am J Med Sci. 2006 Apr;331(4):207-13.

Pataro AL. Associação entre obesidade e condição periodontal: análise epidemiológica e microbiológica em indivíduos obesos, candidatos e submetidos à cirurgia bariátrica [Tese]. Belo Horizonte: Universidade Federal de Minas Gerais; 2010.

Pataro AL, Costa FO, Cortelli SC, Cortelli JR, Dupim Souza AC, Nogueira Guimaraes Abreu MH, et al. Influence of Obesity and Bariatric Surgery on the Periodontal Condition. J Periodontol. 2011 Jul 1.

Pegoraro LF, Scolaro JM, Conti PC, Telles D, Pegoraro TA. Noncarious cervical lesions in adults: prevalence and occlusal aspects. J Am Dent Assoc. 2005 Dec;136(12):1694-700.

Pischon N, Heng N, Bernimoulin JP, Kleber BM, Willich SN, Pischon T. Obesity, inflammation, and periodontal disease. J Dent Res. 2007 May;86(5):400-9.

Price RR, Viscount HB, Stanley MC, Leung KP. Targeted profiling of oral bacteria in human saliva and in vitro biofilms with quantitative real-time PCR. Biofouling. 2007;23(3-4):203-13.

Rai B, Kharb S, Jain R, Anand SC. Biomarkers of periodontitis in oral fluids. J Oral Sci. 2008 Mar;50(1):53-6.

Ramseier CA, Kinney JS, Herr AE, Braun T, Sugai JV, Shelburne CA, et al. Identification of pathogen and host-response markers correlated with periodontal disease. J Periodontol. 2009 Mar;80(3):436-46. 
Reginster JY. The high prevalence of inadequate serum vitamin $D$ levels and implications for bone health. Curr Med Res Opin. 2005 Apr;21(4):579-86.

Renquist K. Obesity classification. Obes Surg. 1998 Aug;8(4):480.

Riep B, Edesi-Neuss L, Claessen F, Skarabis H, Ehmke B, Flemmig TF, et al. Are putative periodontal pathogens reliable diagnostic markers? J Clin Microbiol. 2009 Jun;47(6):1705-11.

Ritchie CS. Obesity and periodontal disease. Periodontol 2000. 2007;44(1):154-63.

Rubio MA, Moreno C. Implicaciones nutricionales de la cirugia bariatrica sobre el tracto gastrointestinal. Nutr Hosp. 2007 May;22 Suppl 2:124-34.

Sahota O, Mundey MK, San P, Godber IM, Lawson N, Hosking DJ. The relationship between vitamin $\mathrm{D}$ and parathyroid hormone: calcium homeostasis, bone turnover, and bone mineral density in postmenopausal women with established osteoporosis. Bone. 2004 Jul;35(1):312-9.

Sakai VT, Campos MR, Machado MA, Lauris JR, Greene AS, Santos CF. Prevalence of four putative periodontopathic bacteria in saliva of a group of Brazilian children with mixed dentition: 1-year longitudinal study. Int J Paediatr Dent. 2007 May;17(3):192-9.

Sakamoto M, Suzuki M, Umeda M, Ishikawa I, Benno Y. Reclassification of Bacteroides forsythus (Tanner et al. 1986) as Tannerella forsythensis corrig., gen. nov., comb. nov. Int J Syst Evol Microbiol. 2002 May;52(Pt 3):841-9.

Sales-Peres SHdC. Identificação de Problemas. In: Saúde bucal coletiva. São Paulo: Editora Santos; 2008. p. 157-286.

Sales-Peres SHdC, Goya S, Araújo JJ, Sales-Peres A, Lauris JR, Magalhães MAR. Prevalence of dental wear among 12-year-old Brazilian adolescents using a modification of the tooth wear index. Public Health. 2008;122:942-8.

Sarlati F, Akhondi N, Ettehad T, Neyestani T, Kamali Z. Relationship between obesity and periodontal status in a sample of young Iranian adults. Int Dent J. 2008 Feb;58(1):36-40.

Scheutzel P. Etiology of dental erosion--intrinsic factors. Eur J Oral Sci. 1996 Apr;104(2 ( Pt 2)):178-90.

Schmittgen TD, Livak KJ. Analyzing real-time PCR data by the comparative $\mathrm{C}(\mathrm{T})$ method. Nat Protoc. 2008;3(6):1101-8.

Sears D, Fillmore G, Bui M, Rodriguez J. Evaluation of gastric bypass patients 1 year after surgery: changes in quality of life and obesity-related conditions. Obes Surg. 2008 Dec;18(12):1522-5.

Segal JB, Clark JM, Shore AD, Dominici F, Magnuson T, Richards TM, et al. Prompt reduction in use of medications for comorbid conditions after bariatric surgery. Obes Surg. 2009 Dec;19(12):1646-56. 
Sheiham A, Steele JG, Marcenes W, Finch S, Walls AW. The relationship between oral health status and Body Mass Index among older people: a national survey of older people in Great Britain. Br Dent J. 2002 Jun 29;192(12):703-6.

Shikora SA, Kim JJ, Tarnoff ME. Nutrition and gastrointestinal complications of bariatric surgery. Nutr Clin Pract. 2007 Feb;22(1):29-40.

Silva B. Condição de saúde bucal em pacientes submetidos à cirurgia bariátrica [dissertação]. Piracicaba: Faculdade de Odontologia de Piracicaba; 2008.

Silva BC, Camargos BM, Fujii JB, Dias EP, Soares MM. Prevalência de deficiência e insuficiência de vitamina $\mathrm{D}$ e sua correlação com PTH, marcadores de remodelação óssea e densidade mineral óssea, em pacientes ambulatoriais. Arq Bras Endocrinol Metabol. 2008 Apr;52(3):482-8.

Silva SRd. Medicina Periodontal: a arte da integração. Rev Assoc Paul Cir Dent. 2004;58(1):7-17.

Sobral M, Luz M, Teixeira A, Garone-Netto N. Influência da dieta ácida no desenvolvimento de erosão dental. Pesqui Odontol Bras. 2000 out/dez;14(4):406-10.

Socransky SS, Haffajee AD, Cugini MA, Smith C, Kent RL, Jr. Microbial complexes in subgingival plaque. J Clin Periodontol. 1998 Feb;25(2):134-44.

Socransky SS, Haffajee AD, Smith C, Dibart S. Relation of counts of microbial species to clinical status at the sampled site. J Clin Periodontol. 1991 Nov;18(10):766-75.

Staud R. Vitamin D: more than just affecting calcium and bone. Curr Rheumatol Rep. 2005 Oct;7(5):356-64.

Sutin AR, Terracciano A, Ferrucci L, Costa PT, Jr. Teeth Grinding: Is Emotional Stability related to Bruxism? J Res Pers. 2010 Jun;44(3):402-5.

Suvan J, D'Aiuto F, Moles DR, Petrie A, Donos N. Association between overweight/obesity and periodontitis in adults. A systematic review. Obes Rev. 2011 May;12(5):e381-404.

Tai CM, Lee YC, Tu HP, Huang CK, Wu MT, Chang CY, et al. The relationship between visceral adiposity and the risk of erosive esophagitis in severely obese Chinese patients. Obesity (Silver Spring). 2010 Nov;18(11):2165-9.

Tamura K, Nakano K, Nomura R, Miyake S, Nakagawa I, Amano A, et al. Distribution of Porphyromonas gingivalis fimA genotypes in Japanese children and adolescents. J Periodontol. 2005 May;76(5):674-9.

ten Cate JM, Imfeld T. Dental erosion, summary. Eur J Oral Sci. 1996 Apr;104(2 ( Pt 2)):241-4.

Togashi AY, Montanha FP, Tárzia O. Levantamento epidemiológico do fluxo salivar da população da cidade de Bauru, na faixa etária de 3 a 90 anos. Revista da Faculdade de Odontologia de Bauru. 1998;6(2):47-52. 
Touger-Decker R, Mobley CC. Position of the American Dietetic Association: oral health and nutrition. J Am Diet Assoc. 2007 Aug;107(8):1418-28.

Traebert J, Moreira EAM, Bosco VL, Almeida ICS. Transição alimentar: problema comum à obesidade e à cárie dentária. Rev Nutr. 2004;17(2):247-53.

Trombone AP, Cardoso CR, Repeke CE, Ferreira SB, Jr., Martins W, Jr., Campanelli $A P$, et al. Tumor necrosis factor-alpha $-308 \mathrm{G} / \mathrm{A}$ single nucleotide polymorphism and red-complex periodontopathogens are independently associated with increased levels of tumor necrosis factor-alpha in diseased periodontal tissues. J Periodontal Res. 2009 Oct;44(5):598-608.

Tsiftsis DD, Mylonas P, Mead N, Kalfarentzos F, Alexandrides TK. Bone mass decreases in morbidly obese women after long limb-biliopancreatic diversion and marked weight loss without secondary hyperparathyroidism. A physiological adaptation to weight loss? Obes Surg. 2009 Nov;19(11):1497-503.

Tucker ON, Szomstein S, Rosenthal RJ. Nutritional consequences of weight-loss surgery. Med Clin North Am. 2007 May;91(3):499-514, xii.

Valderas JP, Velasco S, Solari S, Liberona Y, Viviani P, Maiz A, et al. Increase of bone resorption and the parathyroid hormone in postmenopausal women in the longterm after Roux-en-Y gastric bypass. Obes Surg. 2009 Aug;19(8):1132-8.

Vasques F, Martins FC, Azevedo AP. Aspectos psiquiátricos do tratamento da obesidade. Rev Psiq Clin 2004;31(4):195-8.

Vgontzas AN, Papanicolaou DA, Bixler EO, Kales A, Tyson K, Chrousos GP. Elevation of plasma cytokines in disorders of excessive daytime sleepiness: role of sleep disturbance and obesity. J Clin Endocrinol Metab. 1997 May;82(5):1313-6.

von Bultzingslowen I, Sollecito TP, Fox PC, Daniels T, Jonsson R, Lockhart PB, et al. Salivary dysfunction associated with systemic diseases: systematic review and clinical management recommendations. Oral Surg Oral Med Oral Pathol Oral Radiol Endod. 2007 Mar;103 Suppl:S57 e1-15.

WHO. Oral health surverys: basic methods. Geneva; 1997.

WHO. Obesity: preventing and managing the global epidemic. Report of a WHO Consultation on obesity Geneva: World Health Organization. 1998.

Williams SA, Slatko BE, McCarrey JR. Laboratory investigations in molecular biology. Sudbury: Jones \& Bartlett Learning; 2007.

Williams SE, Cooper K, Richmond B, Schauer P. Perioperative management of bariatric surgery patients: focus on metabolic bone disease. Cleve Clin J Med. 2008 May;75(5):333-4, 6, 8 passim.

Wood N, Johnson RB, Streckfus CF. Comparison of body composition and periodontal disease using nutritional assessment techniques: Third National Health and Nutrition Examination Survey (NHANES III). J Clin Periodontol. 2003 Apr;30(4):321-7. 
Wu T, Trevisan M, Genco RJ, Falkner KL, Dorn JP, Sempos CT. Examination of the relation between periodontal health status and cardiovascular risk factors: serum total and high density lipoprotein cholesterol, C-reactive protein, and plasma fibrinogen. Am J Epidemiol. 2000 Feb 1;151(3):273-82.

Yoshida A, Kawada M, Suzuki N, Nakano Y, Oho T, Saito T, et al. TaqMan real-time polymerase chain reaction assay for the correlation of Treponema denticola numbers with the severity of periodontal disease. Oral Microbiol Immunol. 2004 Jun;19(3):196200.

Zagorski SM, Papa NN, Chung MH. The effect of weight loss after gastric bypass on C-reactive protein levels. Surg Obes Relat Dis. 2005 Mar-Apr;1(2):81-5.

Zhao Y, Encinosa W. Bariatric Surgery Utilization and Outcomes in 1998 and 2004. Healthcare Cost and Utilization Project (HCUP) Statistical Briefs. 2006 Feb;23. 
Apêndice 



\section{APÊNDICE A - TERMO DE CONSENTIMENTO LIVRE E ESCLARECIDO}

\section{TÍTULO DO ESTUDO: "Pacientes bariátricos e análise da presença de DNA de bactérias periodontopatogênicas: um estudo longitudinal"}

INVESTIGADORES: Patrícia Garcia de Moura, Juliane Avansini Marsicano, Prof. Dr. Reginaldo Ceneviva (HC-USP/Ribeirão), Prof. Ms. Gilberto Borges de Brito (HB-FAMERP), Prof. Dr. Celso Vieira de Souza Leite (HC-Unesp/Botucatu), Profa. Dra. Silvia Helena de Carvalho Sales-Peres (FOB/USP).

1- Justificativa, objetivos do estudo e benefício

O Sr./Sra. está sendo convidado/a a participar da pesquisa, ficando a sua escolha aceitar ou não fazer parte deste projeto. E esclarecendo que a não participação na pesquisa não prejudicará o atendimento fornecido por este hospital.

Esta pesquisa tem o objetivo de analisar a qualidade da saúde da boca dos pacientes bariátricos (cirurgia de redução do estomago). Indivíduos obesos estão susceptíveis às doenças da boca, como a doença periodontal e, a cirurgia pode ou não interferir neste processo. Além disso, refluxos e vômitos fazem com que o ácido presente no estomago suba para a boca e assim podendo causar alterações na boca, como causar desgaste e dor nos dentes. O participante, após aceitar colaborar com a pesquisa, responderá a um questionário com questões relacionadas aos hábitos bucais e alimentares do dia a dia, questões sobre cuidados com higiene da boca e autopercepção em relação à sua saúde bucal. Os pacientes serão avaliados a partir de exames clínicos para verificar a presença de desgaste dentário, doença periodontal e analisar o fluxo salivar. Todos os participantes receberão instruções sobre os cuidados de higiene bucal, doenças bucais e hábitos alimentares e dietéticos, sendo oferecido folder educativo. As informações obtidas no questionário e nos exames são sigilosas (confidencial) e utilizadas apenas para os objetivos desta pesquisa. Caso algum detalhe não esteja claro o senhor/a poderá solicitar maiores detalhes com os pesquisadores.

2- Desconforto e riscos possíveis

Os riscos para os pacientes que participam desta pesquisa são próximos à zero. Isto porque ocorrerá apenas a aplicação de questionários e análise observacional (não será feito nenhum tratamento irreversível) que são procedimentos considerados não invasivos e os resultados serão sigilosos. Por outro lado, o paciente se beneficiará, visto que poderá receber diagnostico de problemas bucais e receber encaminhamento, e no caso de apresentar xerostomia (boca seca) acompanhamento e também orientações.

3-Métodos alternativos

Não existem métodos alternativos com a mesma precisão diagnóstica que os exames propostos na avaliação da saúde bucal.

Outras informações importantes

1. Há a garantia de receber respostas a quaisquer perguntas sobre os procedimentos, riscos e benefícios relacionados à pesquisa.

2. Há a liberdade de retirar seu consentimento a qualquer momento e deixar de participar da pesquisa, sem que isto traga qualquer prejuízo à continuidade do seu tratamento médico.

3. Há a segurança de que não será identificado nesta pesquisa e que será mantido o caráter confidencial das informações relacionadas à sua privacidade.

4. Há a garantia de que caso haja gastos adicionais relacionados à participação na pesquisa serão devolvidos (ressarcidos) pelos pesquisadores.

5. Todo material de consumo será oferecido e patrocinado pelos pesquisadores, durante o desenvolvimento da pesquisa.

Informações de nomes, endereços e telefones dos responsáveis pelo acompanhamento do estudo, para contato em caso de intercorrências clínicas:

* Patrícia Garcia de Moura - Telefone- 11- 9350-5680 
* Juliane Avansini Marsicano - Telefone- 18-8118-0812

* Prof. Dra. Sílvia Helena de Carvalho Sales Peres - Telefone- 14-32358260

Departamento de Odontopediatria, Ortodontia e Saúde Coletiva Faculdade de Odontologia de Bauru- FOB/USP

Alameda Octávio Pinheiro Brisola, 9-75 CEP- 17012901- Bauru- SP/BR

* Prof. Dr. Reginaldo Ceneviva - Departamento de Cirurgia e Anatomia HCFMRP/USP Faculdade de Medicina de Ribeirão Preto da USP.

Avenida Bandeirantes, 3900, Monte Alegre CEP- 14078-900 - Ribeirao Preto - SP/BR Telefone: 16-6022508

* Prof. Gilberto Borges de Brito - Departamento de Cirurgia - HB/Famerp -

Av. Brigadeiro Faria Lima, 5416 - Vila São Pedro - CEP - 15090-000

São José do Rio Preto - SP/BR Fone: (17) 3201-5700

* Prof. Dr. Celso Vieira de Souza Leite - Supervisão do HC - HC/FMB/UNESP

Hospital das Clínicas - Faculdade de Medicina - Distrito de Rubião Júnior, s/n

Caixa postal 530 - CEP 18618-970 - Botucatu - SP/BR Fone:14-3815-1466

Eu,

assinado,

natural

de

abaixo

domiciliado com registro do hospital

,

autorizo minha participação no trabalho de

pesquisa intitulado: “Análise da presença de DNA de bactérias periodontopatogênicas, em pacientes bariátricos: um estudo longitudinal."

de 20

Paciente:

$R G$ :

Testemunhas:

$R G$ :

$R G$ :

Cirurgiã-Dentista:

$R G$ : 


\section{APÊNDICE B - FICHA DE IDENTIFICAÇÃO DO PACIENTE}

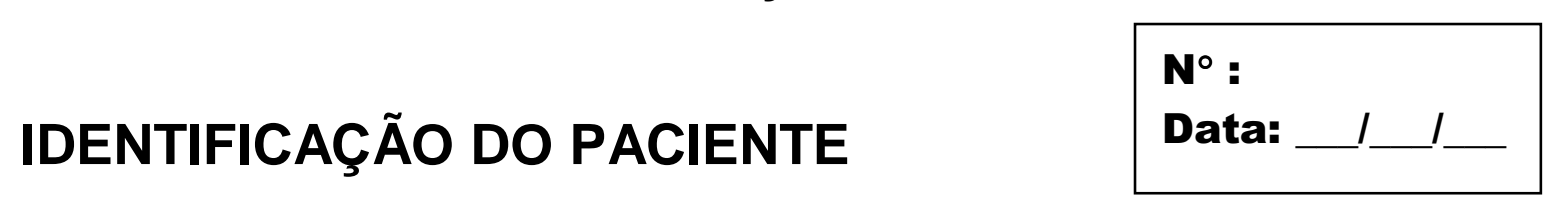

Nome

Endereço-Rua $\mathrm{n}^{\circ}$

Bairro Cidade

UF

Telefone( _ _ Celular(_ _

Est.Civil Idade Data Nascimento:

Gênero Cor Profissão

\section{Informações médicas:}

Co-morbidades:

Medicamentos utilizados pelo paciente:

Cálcio: data do exame:

Proteína C-reativa: data do exame: PTH: data do exame:

Glicemia: data do exame:

\section{IMC:}

Peso $(\mathrm{Kg})$ $=$

Altura $^{2}(\mathrm{~m})$

Data da cirurgia: : 


\section{APÊNDICE C - QUESTIONÁRIOS}

\section{$\mathbf{N}^{\circ}$ :}

Data:

Favor PREENCHER COM "X" A ALTERNATIVA CORRESPONDENTE A SUA RESPOSTA EM CADA QUESTÃO - os dados coletados serão tratados de forma estritamente confidencial, não sendo identificados em hipótese alguma.

1. Com que frequência você toma refrigerantes?

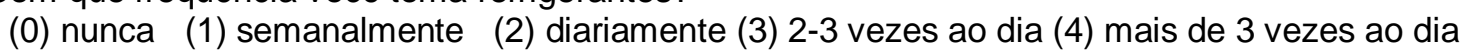

2. Com qual frequência você toma bebidas alcoólicas?
(0) nunca (1) semanalmente
(2) diariamente(3) 2-3 vezes ao dia
(4) mais de 3 vezes ao dia

3. Você tem algum problema estomacal. Qual é este problema?
(0) nenhum
(1) dor estomacal/ gastrite
(2) úlcera
(3) refluxo
(4) vômitos freqüentes

4. Com que frequência você tem vômitos ou refluxo?
0) nunca (1) semanalmente
(2) diariamente (3) 2-3 vezes ao dia (4) r
(4) mais de 3 vezes ao dia

5. Quantas vezes por dia você escova os dentes?

0) nunca (1) semanalmente (2) diariamente (3) 2-3 vezes ao dia (4) mais de 3 vezes ao dia

6. Ao acordar, você sente dores na região dos maxilares?
(1) Não
(2) $\mathrm{Sim}$

7. Alguém já observou que você range os dentes ao dormir (bruxismo)?
(1) Não
(2) Sim

8. Quando está nervoso(a), você tem o hábito de apertar os dentes com força?
(1) Não
(2) $\operatorname{Sim}$

9. Você tem o hábito de morder objetos?
(1) Não
(2) Sim: O que?

\section{Autopercepção em Saúde Bucal}

1. Como classificaria sua saúde bucal?
(1) Péssima
( 2 ) Ruim ( 3 ) Regular
( 4 ) Boa
( 5 ) Ótima

2. Como classificaria a aparência de seus dentes e gengivas?
(1) Péssima
( 2 ) Ruim ( 3 ) Regular
( 4 ) Boa
( 5 ) Ótima

3. Como classificaria sua mastigação?
(1) Péssima
( 2 ) Ruim ( 3 ) Regular
( 4 ) Boa
( 5 ) Ótima

4. Como classificaria a sua fala devido aos seus dentes e gengivas?
(1) Péssima
( 2 ) Ruim ( 3 ) Regular
( 4 ) Boa
( 5 ) Ótima

5. De que forma a sua saúde bucal afeta o seu relacionamento com outras pessoas?
(1) Muito
( 2 ) Mais ou menos ( 3 ) Pouco
( 4 ) Muito pouco
( 5 ) Não afeta

6. O quanto de dor seus dentes e gengivas causaram nos últimos 6 meses?
(1) Muita Dor
( 2 ) Média Dor
( 3 ) Pouca Dor
( 4 ) Nenhuma Dor 


\section{APÊNDICE D - FICHA PARA DESGASTE DENTÁRIO E FLUXO SALIVAR}

Índice adaptado para desgaste dental

$\mathbf{N}^{\circ}$ :

Data:

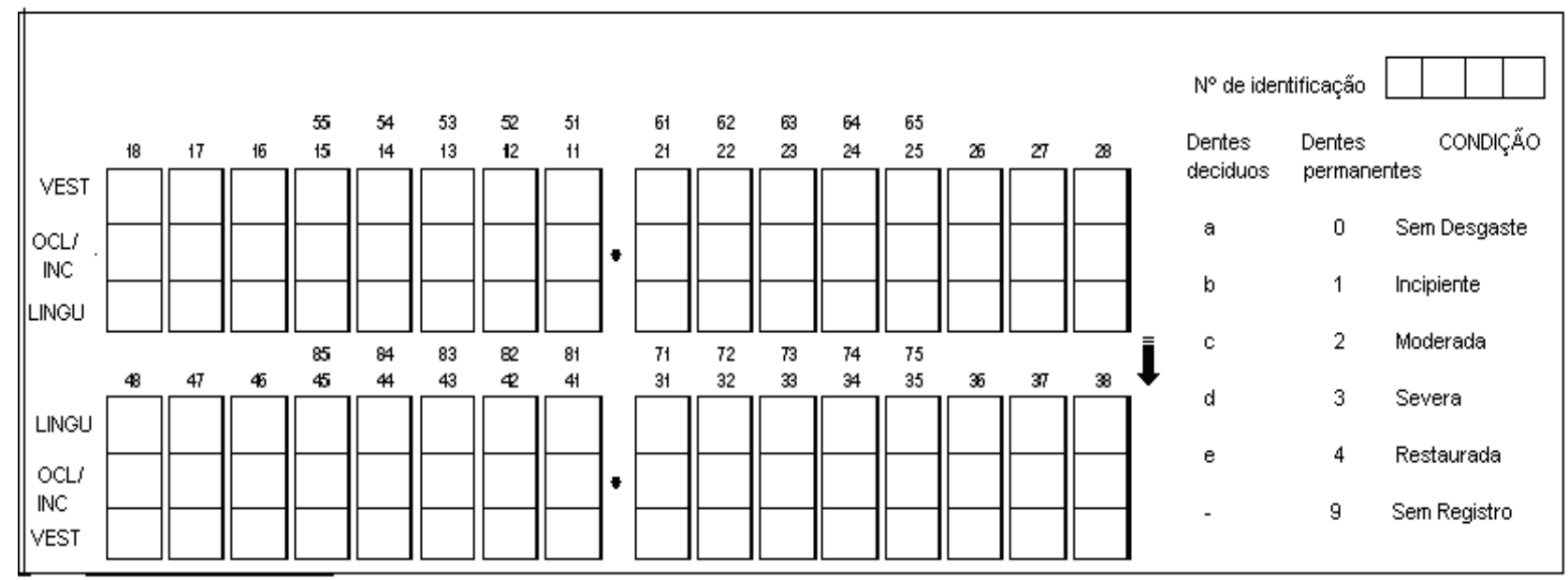

\section{Fluxo salivar:}

$\operatorname{Vol}(\mathrm{mL})=$ $=$

$\operatorname{Min}(5 \mathrm{~min})$ 
APÊNDICE E - FICHA PARA O EXAME PERIODONTAL

Exame periodontal

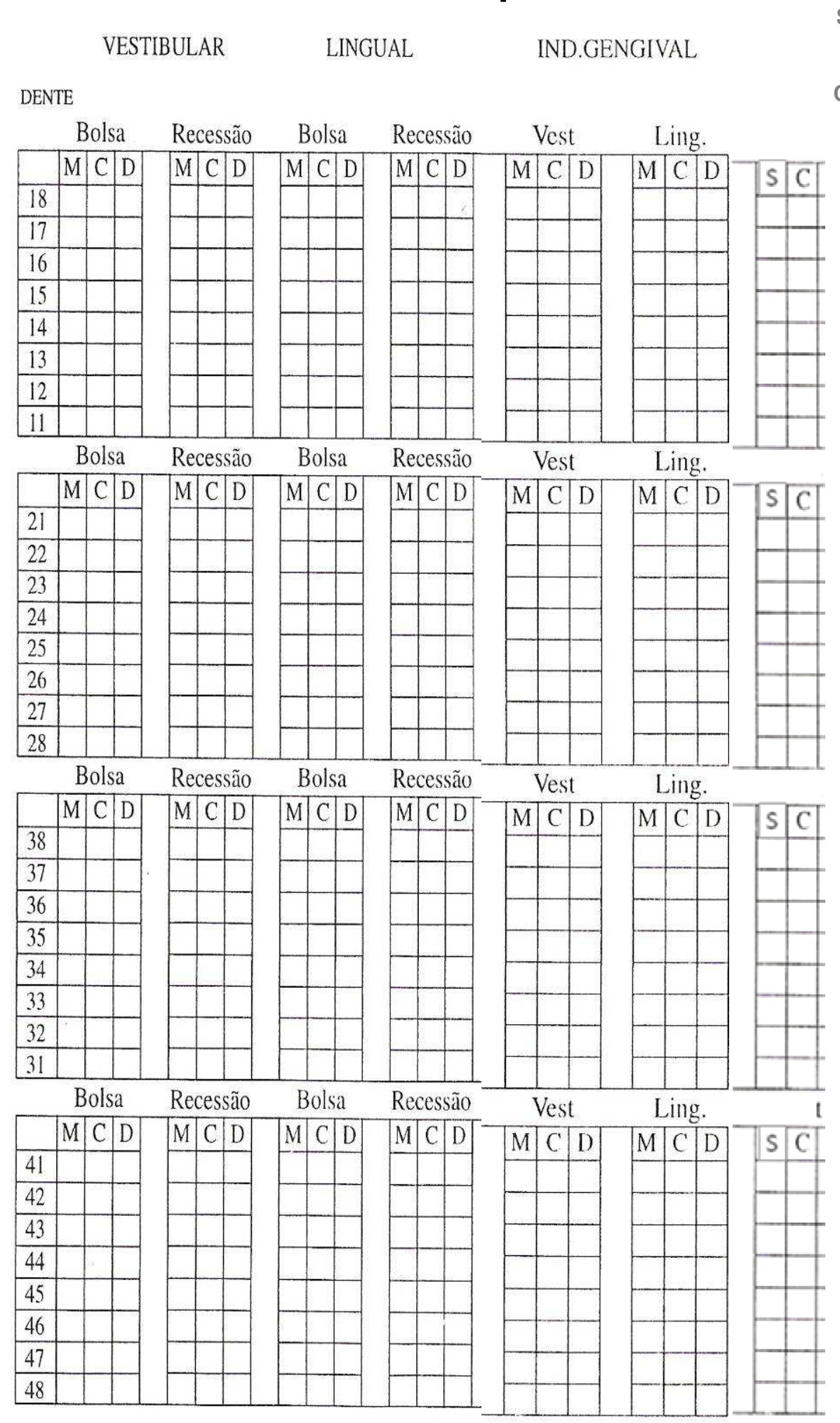

(S) e

Cálculo

(C)

$N^{\circ}$ :

Data: 


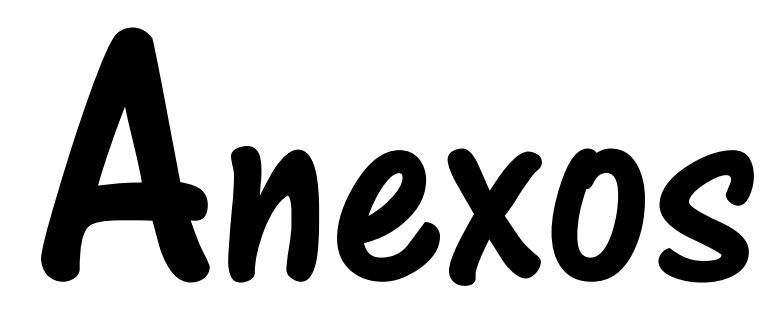



ANEXO A - Protocolo de aprovação do CEP do Hospital de Base - Faculdade de Medicina de São José do Rio Preto (HB/FAMERP)

\title{
FACULDADE DE MEDICINA DE SÃo JOSÉ DO RIO PRETO
}

\author{
Autarquia Estadual - Lei n. ${ }^{\circ} 8899$ de 27/09/94
}

(Reconhecida pelo Decreto Federal n. 74.179 de 14/06/74)

\author{
Parecer $n^{\circ} 315 / 2008$
}

COMITÊ DE ÉTICA EM PESQUISA

O Protocolo $n^{\circ} 4573 / 2008$ sob a responsabilidade de Patrícia Garcia de Moura com o título "Pacientes bariátricos e análise da presença de DNA de bactérias periodontopatogênicas: um estudo longitudinal" está de acordo com a resolução CNS $196 / 96$ e foi aprovado por esse CEP.

Lembramos ao senhor(a) pesquisador(a) que, no cumprimento da Resolução 251/97, ○ Comitê de Ética em Pesquisa em Seres Humanos (CEP) deverá receber relatórios semestrais sobre o andamento do Estudo, bem como a qualquer tempo e a critério do pesquisador nos casos de relevância, além do envio dos relatos de eventos adversos, para conhecimento deste Comitê. Salientamos ainda, a necessidade de relatório completo ao final do Estudo.

São José do Rio Preto, 11 de agosto de 2008.

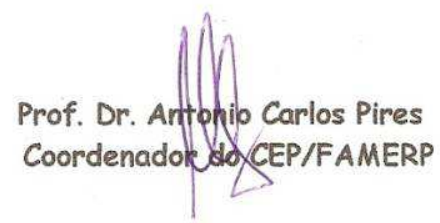


ANEXO B - Protocolo de aprovação do CEP do Hospital das Clínicas de Botucatu UNESP (HC/FMB-UNESP)

\section{Iniversidade Estadual Paulista \\ InESO Faculdade de Medicina de Botucatu}

Distrito Rubião Junior, $s / n^{\circ}$ - Botucatu - S.P.

CEP: $18.618-970$

Fone/Fax: (0xx14) 3811-6143

e-mail secretaria: capellup@fmb.unesp.br

e-mail coordenação: tsarden@.mb.unesp.br

Registrado no Ministério da Saúde em 30 de abril de 1997

Botucatu, 03 de novembro de 2008

Of. $468 / 08-C E P$

Ilustríssima Senhora

Prof ${ }^{a}$. Dr ${ }^{a}$. Silvia Helena de Carvalho Sales Pereira

Departamento de Odontopediatria, Ortodontia e Saúde Coletiva

Universidade de São Paulo.

Prezada Prof ${ }^{a}$ Silvia

De ordem do Senhor Coordenador deste CEP, informo que o Projeto de Pesquisa "Análise da presença de DNA de bactérias periodontopatogênicas en pacientes bariátricos: un estudo longitudinal", a ser conduzido por Patrícia Garcia de Moura, orientada por Vossa Senhoria e Co-orientada pelo Prof. Dr. Celso Vieira de Souza Leite, com a colaboração de Reginaldo Ceniviva - Guilherme Borges de Brito e Juliana A. Marsicano recebeu do relator parecer favorável, aprovado em reunião do CEP de 03/11/2008.

Situação do Projeto: APROVADO. Apresentar Relatório Final de Atividades do final da execução deste projeto.

Atenciosamente,

Alberto Santos Capelluppi

Secretário do CEP. 
ANEXO C - Protocolo de aprovação do CEP do Hospital das Clínicas de Ribeirão Preto - Universidade de São Paulo (HCRP/FMRP-USP)

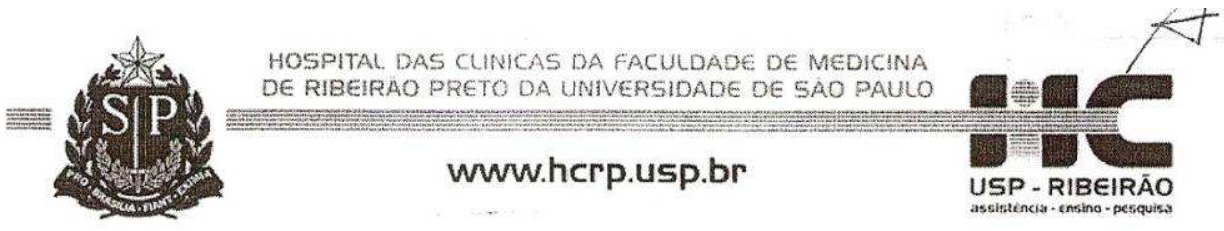

Ribeirão Preto, 17 de março de 2010

Oficio $\mathrm{n}^{\circ} 718 / 2010$

$\mathrm{CEP} / \mathrm{MGV}$

Prezados Senhores,

O trabalho intitulado "ANÁLISE DA PRESENÇA DE DNA DE BACTÉRIAS PERIODONTOPATOGENICAS EM PACIENTES BARIÁTRICOS: UM ESTUDO LONGITUDINAL" foi analisado pelo Comitê de Ética em Pesquisa, em sua $303^{a}$ Reunião Ordinária realizada em 15/03/2010 e enquadrado na categoria: APROVADO, bem como o Termo de Consentimento Livre e Esclarecido, de acordo com o Processo HCRP $n^{\circ} 12384 / 2009$.

Este Comitê segue integralmente a Conferência Internacional de Harmonização de Boas Práticas Clinicas (IGH-GCP), bem como a Resolução $n^{\circ}$ 196/96 CNS/MS.

Lembramos que devem ser apresentados a este CEP, O Relatório Parcial e o Relatório Final da pesquisa. Atenciosamente.

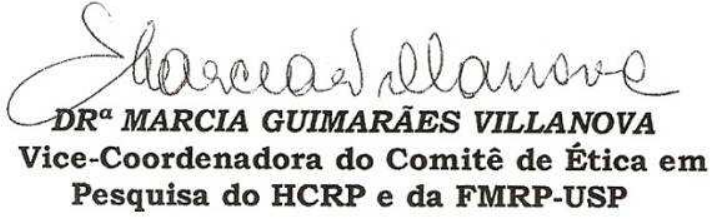

Ilustríssimos Senhores

PATRÍCIA GARCIA DE MOURA

PROF. DR. REGINALDO CENEVIVA (Co-Orientador)

Faculdade de Odontologia de Bauru

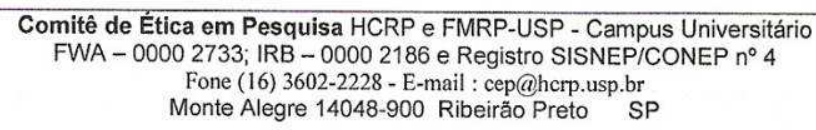




\section{ANEXO D - Autorização de captação e exibição de imagem}

\section{AUTORIZAÇÃO DE CAPTAÇÃO E EXIBIÇÃO DE IMAGEM, SOM E NOME}

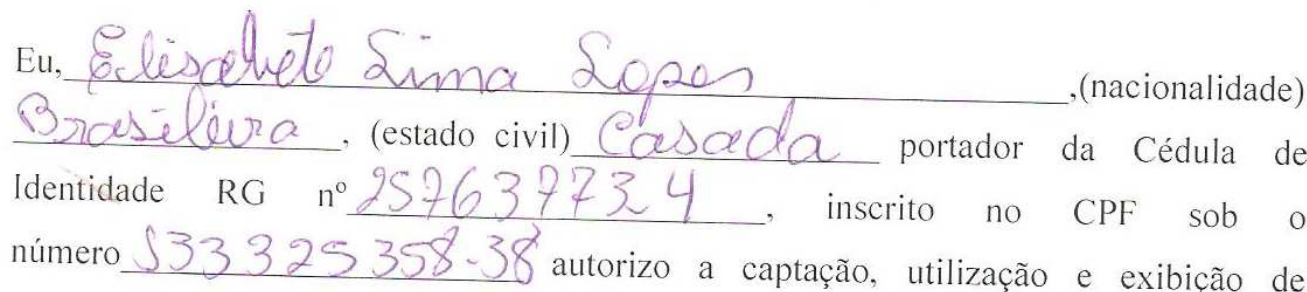
minha imagem pela Faculdade de Odontologia de Bauru - Universidade de São Paulo (FOB-USP), diretamente ou através do Departamento de Odontopediatria, Ortodontia e Saúde Coletiva ou outra entidade vinculada, a serem utilizadas em obras audiovisuais a serem produzidas para fins institucionais, didáticos e/ou científicos, sejam essas destinadas à divulgação ao público em geral e/ou apenas para uso interno desta instituição.

1. A presente autorização, concedida a título gratuito, confere à FOB-USP o direito de utilizar minhas imagens nas obras para veiculação interna, bem como em eventos externos, no Brasil e no exterior, por mídia escrita, eletrônica ou digital, tais como revistas, manuais, portais de Internet, folders, atividades de caráter didático ou científico, trabalhos científicos, programas de Rádio e TV, publicações em geral, entre outros, a critério exclusivo da FOB-USP, desde que não haja desvirtuamento da sua finalidade.

2. Declaro estar ciente de que as imagens captadas nesta ocasião farão parte de um "banco de imagens" pertencente ao Departamento de Odontopediatria, Ortodontia e Saúde Coletiva da FOB-USP e que poderão ser utilizadas a qualquer tempo e de acordo com os critérios da mesma.

3. Por esta ser a expressão da minha vontade declaro que autorizo o uso acima descrito sem que nada haja a ser reclamado a título de direitos conexos à minha imagem ou a qualquer outro título, e assino a presente autorização em 02 (duas) vias de igual teor e forma.
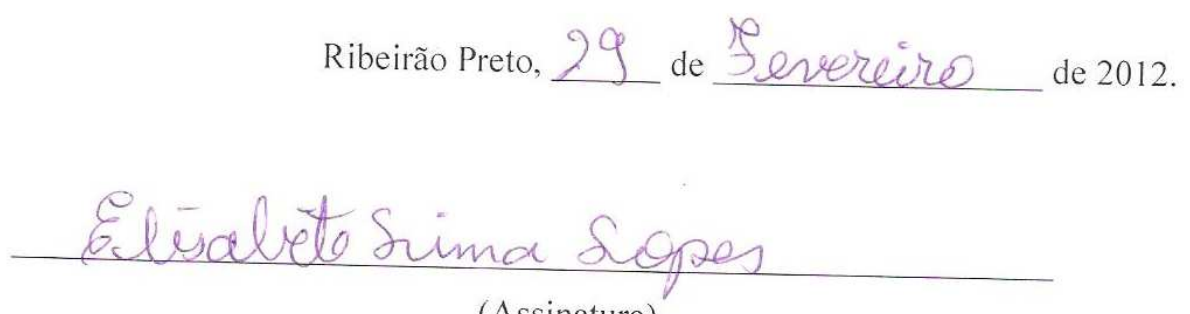

(Assinatura) 